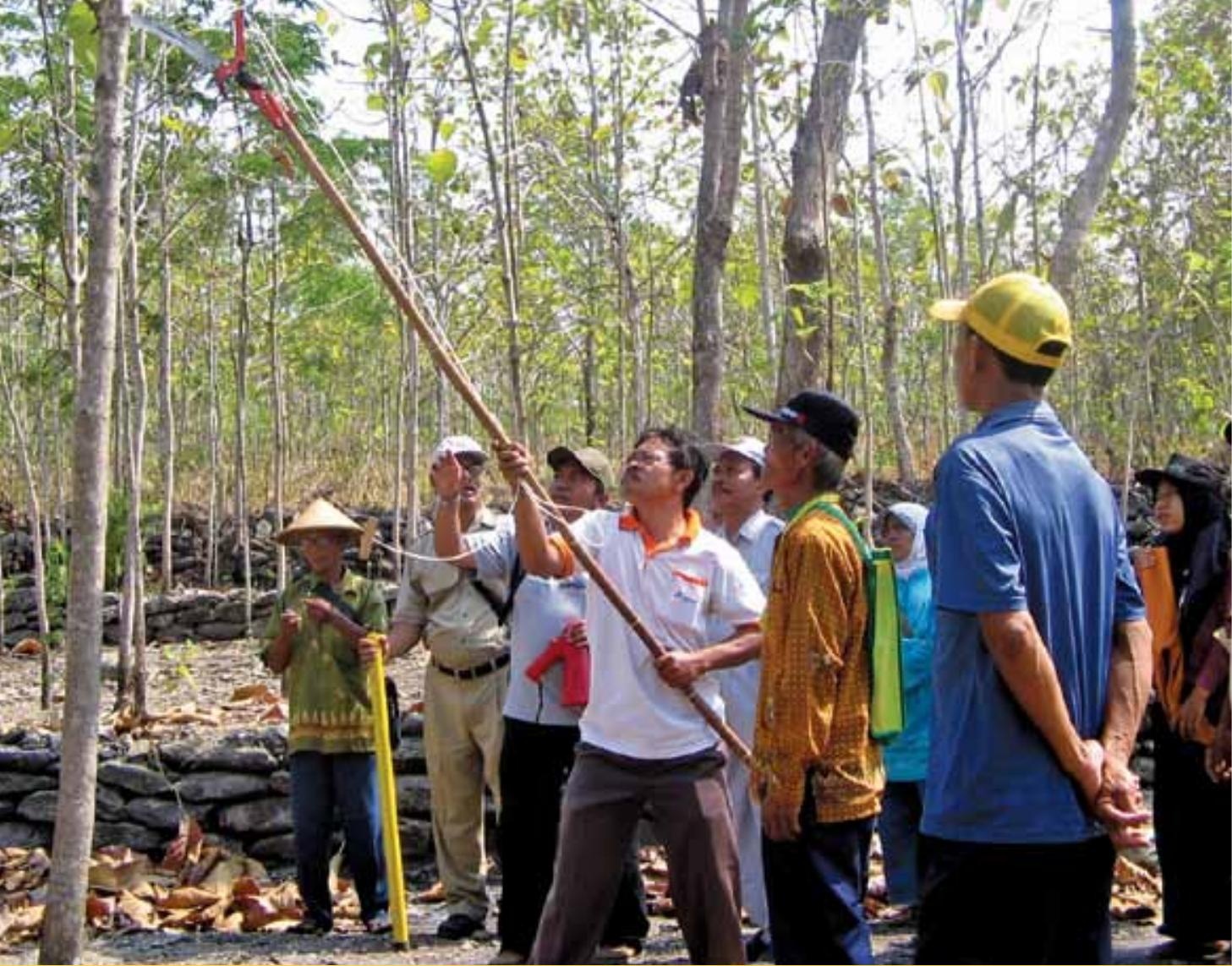

\title{
Pengelolaan Hutan Jati Rakyat Panduan Lapangan untuk Petani
}

Agus Astho Pramono

M. Anis Fauzi

Nurin Widyani

Ika Heriansyah

James M. Roshetko
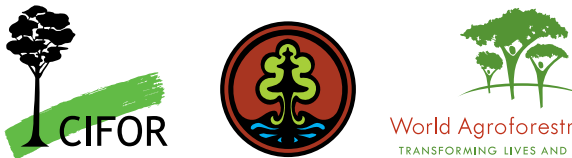

World Agroforestry Centre 



\section{Pengelolaan Hutan Jati Rakyat Panduan Lapangan untuk Petani}

Agus Astho Pramono

M. Anis Fauzi

Nurin Widyani

Ika Heriansyah

James M. Roshetko 
C 2010 Center for International Forestry Research

ISBN: 978-602-8693-19-6

Pramono, A.A., Fauzi, M.A., Widyani, N., Heriansyah, I. dan Roshetko, J.M. 2010. Pengelolaan hutan jati rakyat: panduan lapangan untuk petani. CIFOR, Bogor, Indonesia.

Foto: A. Astho Pramono, M. Anis Fauzi, Philip Manalu dan Illa Anggraeni

llustrasi: A. Astho Pramono

Tata letak: Rahadian Danil

CIFOR

JI. CIFOR, Situ Gede

Bogor Barat 16115

Indonesia

$\mathrm{T}+62$ (251) 8622-622

$\mathrm{F}+62$ (251) 8622-100

E cifor@cgiar.org 


\section{Daftar Isi}

Kata Pengantar dari Penerbit iv

Kata Pengantar dari Penulis vii

1. Pendahuluan 1

2. Silvikultur Jati 5

3. Penyiapan Benih 9

3.1. Pengumpulan benih 10

3.2. Penanganan benih $\quad 16$

4. Pembuatan Bibit 17

4.1. Bibit dari benih $\quad 17$

4.2. Bibit dari setek pucuk $\quad 21$

4.3. Bibit dari sumber lainnya 24

5. Penanaman 29

5.1. Perancangan pola tanam 29

5.2. Persiapan lahan 36

5.3. Penanaman 38

6. Pemeliharaan Tegakan 43

6.1. Pembersihan gulma 43

6.2. Pemupukan $\quad 44$

6.3. Penyulaman 44

6.4. Pemangkasan $\quad 45$

6.5. Penjarangan 48

6.6. Pemeliharaan terubusan $\quad 52$

6.7. Pengendalian hama dan penyakit 53

7. Pemanenan 61

Bahan Bacaan $\quad 65$

Daftar Nama Jenis $\quad 69$

Keterangan Istilah $\quad 71$

$\begin{array}{ll}\text { Lampiran } & 75\end{array}$ 


\section{Kata Pengantar dari Penerbit}

Hutan rakyat dapat diartikan sebagai tanaman kayu yang ditanam pada lahan-lahan milik masyarakat. Keberadaan hutan rakyat di Indonesia semakin penting karena turut menyumbang pasokan kebutuhan kayu bagi industri perkayuan. Disamping itu hutan rakyat merupakan salah satu sarana dalam upaya peningkatan kesejahteraan masyarakat, khususnya yang tinggal di pedesaan.

The Center for International Forestry Research (CIFOR) memberikan perhatian yang cukup besar terhadap upaya pengembangan hutan jati rakyat di Indonesia. Pengembangan hutan rakyat sejalan dengan misi CIFOR dan sudah menjadi salah satu kegiatan utama yang kini termasuk ke dalam domain penelitian (research domain) 3, yaitu "Improving livelihoods through smallholder and community forestry". Ada tiga output utama yang ingin dihasilkan dari Research Domain 3; yaitu yang berkaitan dengan penyempurnaan aspek teknis dalam pengelolaan hutan (tanaman) rakyat dan hutan kemasyarakatan; penyempurnaan model-model pengusahaan, khususnya kelembagaan masyarakat; dan penyempurnaan kebijakan-kebijakan untuk menciptakan iklim usaha yang lebih kondusif bagi masyarakat.

Buku Panduan Pengelolaan Hutan Jati Rakyat ini merupakan salah satu bentuk output penelitian yang berkaitan dengan aspek teknis pengelolaan hutan rakyat, dalam hal ini aspek silvikultur. Buku ini disusun berdasarkan hasil pembelajaran dari kegiatan proyek penelitian "Peningkatan Manfaat Ekonomi Usaha Hutan Jati Rakyat dalam Sistem Agroforestri di Indonesia" yang didanai oleh The Australian Center for International Agricultural Research (ACIAR), kode proyek No FST/2005/177. Penyusunan buku dilakukan oleh mitra penelitian dari Badan Penelitian dan Pengembangan Kehutanan, The World Agroforesrty Center (ICRAF), Winrock International dan Kelompok Kerja Hutan Lestari, Kabupaten Gunungkidul. 
Pada kesempatan ini kami ingin menyampaikan terima kasih yang sebesar-besarnya kepada semua pihak yang telah membantu penyusunan buku panduan ini, khususnya kepada:

- ACIAR yang telah mendanai proyek penelitian ini.

- Para penulis dari lembaga penelitian mitra yang telah melaksanakan kegiatan penelitian dan penyusunan buku ini, serta staf lainnya yang telah memberikan saran dan koreksi, baik secara substansial maupun redaksional, khususnya kepada Saudara Gerhard Manurung, Iwan Kurniawan, Alfan Gunawan Ahmad, Rikola Fedri, Lia Dahlia, Philip Manalu, Illa Anggraeni, Triwilaida dan Muhammad Zanzibar.

- Para tokoh masyarakat dan perwakilan kelompok tani di lokasi penelitian di Kabupaten Gunungkidul, Yogyakarta atas peran sertanya di dalam kegiatan pengujian kepraktisan buku panduan ini, khususnya kepada para petani seperti yang tertulis pada Lampiran 1.

- Para penyuluh kehutanan di lingkup Kabupaten Gunungkidul, yang telah turut serta di dalam pengujian kepraktisan buku panduan ini, khususnya kepada Bapak Sudiarno, Sunyoto, Adiya PW, Toto Karyoto, Pranowo, Subiyantoro, Supriyadi, dan Y. Bambang Endratno.

- Saudara Beni Silalahi, Taufik J. Purwanto, dan Purnomo Sumardamto dari Dinas Kehutanan Kabupaten Gunungkidul, Yogyakarta atas segala dukungan dan fasilitasinya di dalam pengujian buku panduan ini.

- Puslitbang Sumber Daya Hutan Perhutani Cepu, yang telah memberikan masukan mengenai teknik persemaian.

- Pihak-pihak lain yang telah terlibat di dalam pembahasan serta pencetakan buku panduan ini, yang tidak dapat kami sebutkan satu-persatu. 
Kami berharap agar buku panduan ini bermanfaat bagi para petani hutan jati rakyat, para penyuluh, akademisi serta masyarakat pada umumnya, sebagai bahan panduan dalam upaya peningkatan produktivitas hutan jati rakyat.

Bogor, 2010

Atas nama Penerbit

Dede Rohadi

Pemimpin Proyek

Penelitian ACIAR FST/2005/177

Peningkatan Manfaat Ekonomi Usaha Hutan Rakyat Jati dalam Sistem Agroforestri di Indonesia 


\section{Kata Pengantar dari Penulis}

Dewasa ini, menanam kayu telah menjadi pilihan investasi yang menguntungkan bagi masyarakat. Adalah jati (Tectona grandis L.f.), penghasil kayu mewah yang telah menjadi daya tarik petani di Kabupaten Gunungkidul untuk mengubah lahan tandus mereka menjadi kebun sumber uang. Dimulai sejak dasawarsa 1960-an oleh beberapa petani perintis, pohon-pohon jati telah berperan sebagai tabungan jangka panjang untuk keperluan rumah tangga yang membutuhkan biaya besar. Namun demikian, produktivitas dan kualitas kayu yang rendah menjadi kendala untuk mendapatkan keuntungan maksimal dari hutan jati mereka.

Teknik silvikultur merupakan salah satu kunci dalam peningkatan produktivitas hutan jati rakyat. Walau jati telah ratusan tahun akrab dengan kehidupan petani di Jawa, namun umumnya petani masih miskin pengetahuan tentang bagaimana sebenarnya teknik yang tepat untuk mengelola hutan jati. Pada umumnya petani masih menggunakan pola "tanam dan biarkan tumbuh sendiri". Teknik pemangkasan atau pruning, pemeliharaan trubusan atau singling dan penjarangan atau thinning masih merupakan bahasa asing di dalam kosa kata mereka.

Berawal dari perkembangan hutan jati rakyat di Gunungkidul, buku panduan ini muncul untuk memenuhi kehausan petani akan ilmu pengetahuan dan petunjuk praktis dalam membangun tegakan jati idaman yang bisa dikelola sendiri dan mampu menjadi tumpuan ekonomi rumah tangga. Pohon-pohon jati yang tertata rapi dengan kualitas baik seperti milik Perhutani menjadi salah satu impian dari sebagian petani pengelola hutan jati rakyat. Buku yang sengaja dikemas dengan bahasa sederhana ini, diharapkan dapat memandu petani untuk mewujudkan impian-impian tersebut. Melalui buku ini, diharapkan kualitas tegakan dan harga jual jati rakyat akan meningkat secara nyata. 
Hutan jati rakyat adalah fokus buku ini, karena hutan rakyat memiliki ciri yang berbeda dari hutan tanaman pada umumnya. Permasalahanpermasalahan yang dihadapi dalam pengelolaan hutan rakyat yang kadang spesifik antar lokasi seringkali tidak terjawab oleh buku-buku pedoman yang ada selama ini. Bagaimana mengatur jarak tanam jati pada lahan berbatu, dan bagaimana teknik penjarangan pada tegakan yang umurnya tidak seragam, adalah beberapa hal yang dicoba dijawab oleh buku ini. Adopsi dari pola tebang butuh dan beberapa kearifan tradisional juga dikemukakan di sini.

Teknik yang disampaikan dalam buku ini merupakan hasil kumpulan berbagai informasi dari studi pustaka, komunikasi pribadi dengan pakar, peneliti, praktisi pengelola jati di Perum Perhutani, pengalaman petani dan penyuluh kehutanan di Kabupaten Gunungkidul, serta pengalaman penulis sendiri. Sebagian informasi di dalam buku ini juga dihasilkan dari kegiatan proyek penelitian ACIAR berjudul "Peningkatan Manfaat Ekonomi Usaha Hutan Rakyat Jati dalam Sistem Agroforestri di Indonesia" yang melibatkan penelitipeneliti dari CIFOR, ICRAF, Winrock International, International Center for Applied Finance and Economics (InterCAFE) - IPB, Badan Litbang Kehutanan, Australian National University, dan Kelompok Kerja (Pokja) Hutan Rakyat Lestari, Kabupaten Gunungkidul.

Semoga buku panduan ini dapat meningkatkan pengetahuan teknik silvikultur untuk petani jati di manapun, dan juga bermanfaat bagi para pengambil kebijakan, peneliti, penyuluh, dan semua pihak yang menaruh perhatian pada jati dan budidayanya.

Bogor, 2010 


\section{1}

\section{Pendahuluan}

\section{Mengapa hutan jati rakyat?}

- Jati (Tectona grandis L.f.) dikenal sebagai kayu komersial bermutu tinggi, termasuk dalam suku Verbenaceae. Daerah sebaran asli dari jati meliputi India, Myanmar, dan Thailand.

- Jati pertama kali ditanam di Indonesia (di Pulau Jawa) diperkirakan pada abad ke 2 Masehi, yang dilakukan oleh para penyebar agama Hindu. Saat ini jati telah dikenal secara luas dan dikembangkan oleh pemerintah, swasta, dan petani.

- Tanaman ini telah banyak dikembangkan, bahkan di beberapa tempat menjadi bagian yang tidak terpisahkan dari kehidupan tradisional masyarakat.

- Di Indonesia, tanaman jati secara khusus berpotensi meningkatkan pendapatan dan kesejahteraan petani, pedagang, dan industri pengolahan. Secara umum berperan dalam pembangunan daerah dan nasional.

- Kayu jati dan hasil olahannya memiliki wilayah pemasaran yang luas, di luar maupun di dalam negeri.

- Tanaman jati memiliki masa tebang yang panjang sehingga memiliki fungsi lingkungan dalam pengaturan tata air (hidrologi) dan iklim lokal.

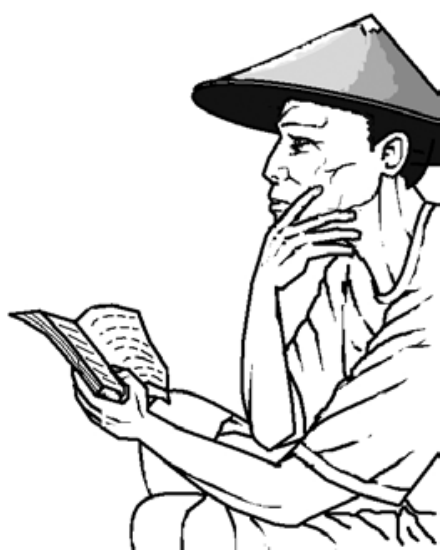




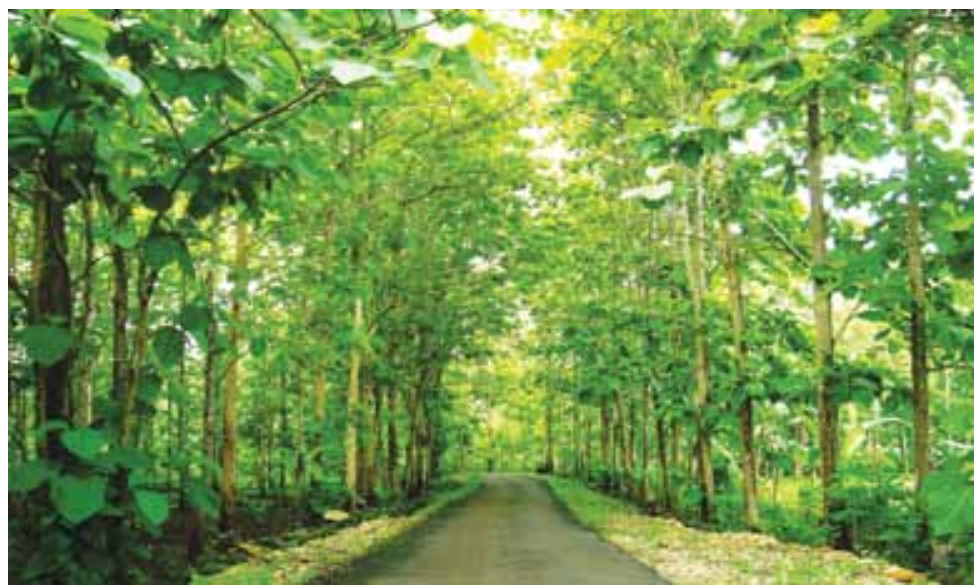

Gambar 1.1. Hutan jati rakyat: Indah, bermanfaat bagi lingkungan, dan menjadi penghasilan untuk masa depan

- Kualitas kayunya yang tinggi, memungkinkan hasil olahannya untuk digunakan dalam jangka waktu yang lama.

- Hampir seluruh bagian dari tanaman jati dapat dimanfaatkan, bahkan salah satu jenis ulatnya (Hyblaea puera) di beberapa daerah menjadi makanan sumber protein yang disukai masyarakat.

\section{Untuk siapa panduan ini?}

Panduan ini diutamakan bagi petani pengelola hutan jati, dan diharapkan juga bermanfaat bagi penyuluh, peneliti, pemerhati, dan pembuat kebijakan.

\section{Mengapa panduan ini dibutuhkan?}

- Pengelolaan hutan jati rakyat umumnya dilaksanakan secara tradisional, sehingga mutu dan jumlah kayu yang dihasilkan masih rendah. 
- Petani masih sulit memperoleh informasi teknis tentang pengelolaan jati, sehingga teknik yang benar belum banyak diterapkan di hutan rakyat.

- Informasi tentang pengelolaan jati yang tersedia saat ini kebanyakan masih ditulis dalam bahasa yang ilmiah, sehingga sulit dipahami, kurang menarik dan kurang praktis untuk petani.

- Berdasarkan uraian di atas, diperlukan suatu buku panduan khusus untuk hutan jati rakyat yang mudah dipahami, ditulis dalam bahasa yang sederhana, dan menarik.

\section{Apakah ruang lingkup panduan ini?}

- Buku ini dibuat sebagai panduan untuk meningkatkan mutu hutan jati rakyat melalui penerapan teknik budidaya (silvikultur) yang baik, dimulai dari pemilihan benih, pembibitan, penanaman, pemeliharaan sampai pemanenan.

- Teknik pengelolaan jati yang dikemukakan adalah teknik yang tidak memerlukan biaya mahal dan sederhana sehingga mudah untuk dilaksanakan oleh petani.

- Panduan ini meliputi pedoman pengembangan jati rakyat, baik hutan sejenis, campuran, maupun tumpangsari. 



\section{2}

\section{Silvikultur Jati}

\section{Apa yang dimaksud dengan silvikultur?}

Silvikultur mempunyai beberapa arti yaitu:

- Ilmu dan seni dalam budidaya tanaman hutan yang didasarkan pada pengetahuan tentang pohon hutan.

- Kegiatan yang berkenaan dengan pembangunan, pengaturan pertumbuhan, susunan jenis tanaman, dan kualitas tegakan hutan.

\section{Adakah kaitan antara kegiatan silvikultur dengan nilai jual kayu jati?}

Nilai jual pohon jati ditentukan oleh kualitas pohon yang dicirikan dengan: ukuran dan kelurusan batang, tinggi batang bebas cabang, kelurusan serat kayu, dan ada tidaknya cacat kayu. Perlakuan silvikultur yang tepat akan mampu meningkatkan mutu pohon jati sehingga meningkatkan nilai jualnya, misalnya:

a. Penggunaan bibit unggul akan menghasilkan pohon yang tumbuh cepat dan berbatang lurus.

b. Pemangkasan cabang (pruning) pada saat jati berumur muda akan menghasilkan batang tanpa cacat mata kayu, dan batang bebas cabang tinggi,

c. Penjarangan (thinning) akan mengurangi persaingan antara pohon dalam memperoleh makanan (hara) dari tanah dan cahaya, sehingga mempercepat pertumbuhan diameter batang.

d. Pemupukan pada tanaman jati akan mempercepat pertumbuhan sehingga menghasilkan kayu yang berukuran besar. 
e. Pengendalian hama dan penyakit akan menjamin pohon tumbuh sehat dan normal sehingga menghasilkan kayu yang berukuran besar dan bebas dari cacat.

\section{Kegiatan apa saja yang termasuk silvikultur jati?}

Kegiatan yang termasuk dalam praktek silvikultur meliputi:

a. Pengadaan benih dan bibit berkualitas.

b. Persiapan lahan, yaitu lahan diolah agar sesuai untuk ditanami bibit jati sehingga bibit dapat tumbuh baik sampai menjadi pohon dewasa.

c. Pengaturan jarak tanam, yaitu jarak antar tanaman diatur agar pemeliharaan lebih mudah dan pertumbuhan pohon lebih cepat.

d. Pemupukan, yaitu penambahan kandungan makanan (hara) ke dalam tanah sehingga pohon jati lebih subur dan sehat.

e. Pemangkasan, yaitu penghilangan atau pemotongan cabang-cabang pada batang utama ketika umur muda, untuk meningkatkan ketinggian batang bebas cabang dan mengurangi mata kayu.

f. Penjarangan, yaitu penebangan untuk memperlebar jarak tanam atau mengurangi jumlah pohon agar pertumbuhan dalam suatu area lebih merata, dan mutunya meningkat.

g. Pencegahan dan penanggulangan hama penyakit.

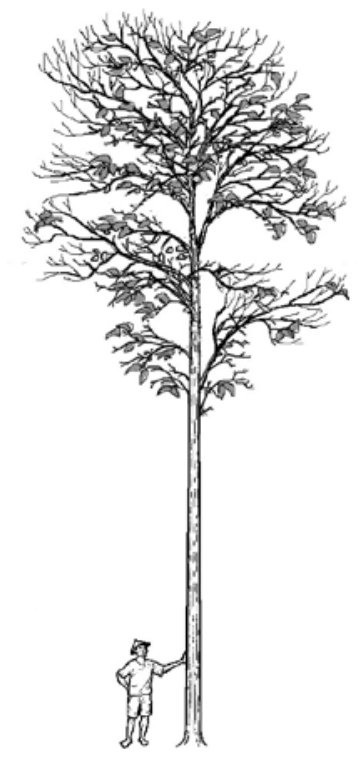

Gambar 2.1. Perlakuan silvikultur yang tepat menghasilkan pohon jati bermutu tinggi

h. Pemanenan, yaitu penebangan pohon untuk dimanfaatkan hasil kayunya.

Keterangan lebih rinci akan dibahas dalam bagian selanjutnya. 


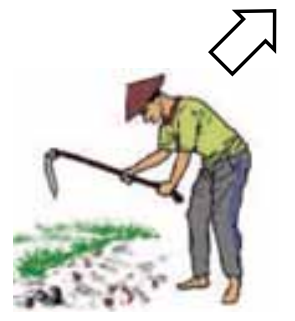

Persiapan lahan

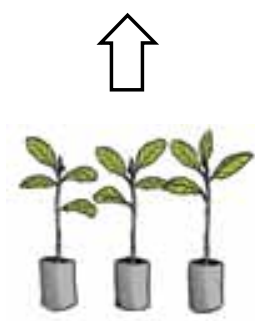

Pengadaan benih dan bibit

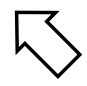

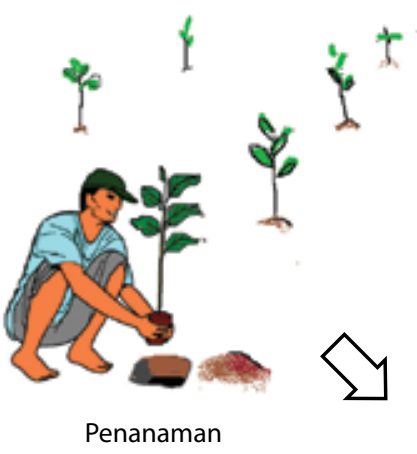

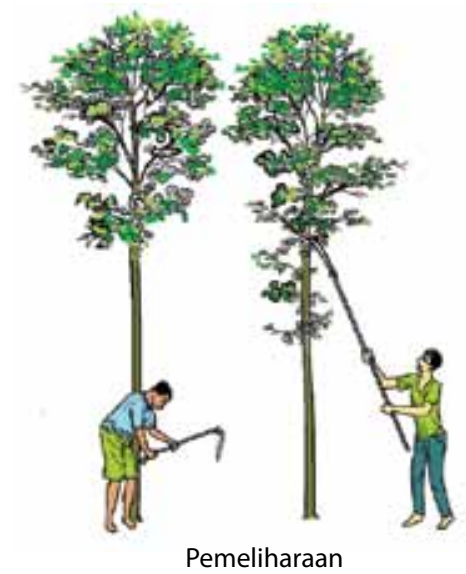

Pemeliharaan<smiles></smiles>

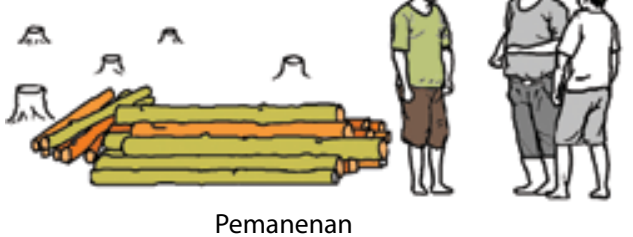

Gambar 2.2. Tahapan kegiatan silvikultur jati 



\section{3}

\section{Penyiapan Benih}

\section{Mengapa benih harus dipersiapkan?}

- Pertumbuhan dan penampilan fisik suatu pohon dipengaruhi oleh faktor keturunan dari induknya (faktor genetik) dan pengaruh lingkungan.

- Tegakan jati yang sehat, tumbuh cepat, dan menghasilkan kayu yang berkualitas dapat diperoleh dari benih yang induknya berkualitas (benih unggul).

- Benih yang unggul akan menunjukkan pertumbuhan yang maksimal jika ditanam pada lahan yang sesuai bagi pertumbuhannya.

- Sebaliknya benih unggul dapat menghasilkan pertumbuhan yang kurang baik jika ditanam pada lahan yang tidak sesuai.

- Untuk mendapatkan bibit berkualitas yang sesuai dengan lahan petani, dan sesuai dengan waktu penanaman, maka pengadaan benih perlu direncanakan dan dilaksanakan dengan baik.
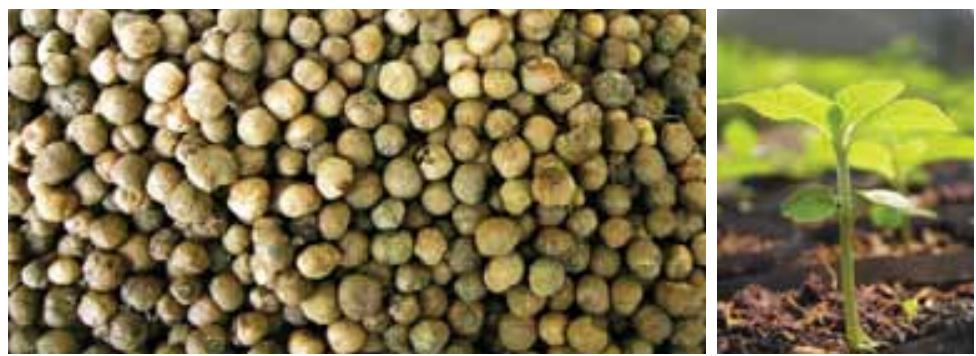

Gambar 3.1. Benih dan bibit jati 


\subsection{Pengumpulan benih}

\section{Dari mana benih dikumpulkan?}

- Benih yang terbaik hendaknya berasal dari kebun benih (Kebun Pangkas, Kebun Benih Semai, Kebun Benih Klon).

- Jika sulit diperoleh, benih bisa diperoleh dari areal produksi benih, atau dari tegakan benih (areal produksi benih, tegakan benih teridentifikasi, tegakan benih terseleksi).

- Jika membeli benih, sebaiknya membeli benih unggul bersertifikat, atau berasal dari sumber yang dapat dipercaya.

- Usahakan benih berasal dari sumber benih yang memiliki kondisi ekologis (ketinggian tempat, iklim, dan tanah) yang mirip dengan lokasi yang akan ditanami.

- Misalnya petani di Gunungkidul yang memiliki lahan kering, tanahnya berkapur, dengan ketinggian tempat 0-400 $\mathrm{m}$ dpl, sebaiknya menggunakan benih dari daerah-daerah yang memiliki kondisi mirip Gunungkidul.

- Jika petani sulit mendapatkan benih dari sumber benih bersertifikat, cara paling mudah dan murah untuk memperoleh benih adalah dengan mengumpulkannya dari pohon benih (pohon induk lokal terbaik di lokasi tersebut).

\section{Apakah pohon benih itu?}

Pohon benih adalah pohon yang dipilih dan dipelihara sebagai penghasil benih.

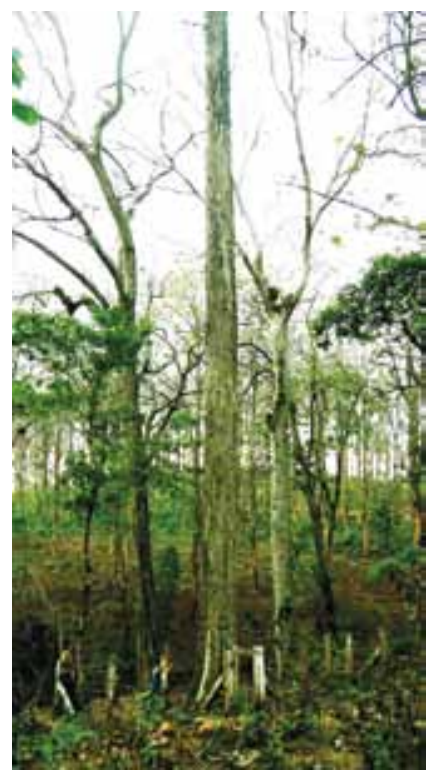

Gambar 3.2. Pohon benih jati (Pohon plus di Perum Perhutani) 


\section{Kelas Sumber Benih}

Sumber benih adalah asal dari mana benih dikumpulkan, dapat berupa:

- sejumlah pohon terpilih pada suatu hamparan lahan (misal pohonpohon yang dipilih di lahan petani atau pohon-pohon yang dipilih di hutan alam), atau

- sekelompok pohon yang tumbuh bersama dalam satu area.

Menurut Peraturan Menteri Kehutanan No: P.01/Menhut-II/2009, sumber benih tanaman hutan dikelompokkan menjadi 7 kelas.

Penjelasan sederhana dari tujuh kelas sumber benih tersebut adalah:

1. Tegakan benih teridentifikasi (TBT), yaitu sumber benih yang tegakannya memiliki mutu seperti tegakan rata-rata. Tegakan benih ini ditunjuk dari hutan alam atau hutan tanaman. Lokasinya terdata dengan tepat.

2. Tegakan benih terseleksi (TBS), yaitu sumber benih yang berasal dari TBT. Mutu tegakannya lebih baik dari tegakan rata-rata.

3. Areal produksi benih (APB), yaitu tegakan yang dibangun (ditanam) khusus sebagai sumber benih. APB juga dapat berasal dari TBT atau TBS yang telah mengalami penjarangan (pohon-pohon yang tidak bagus ditebang).

4. Tegakan benih provenan (TBP), yaitu sumber benih yang dibangun dari benih yang dikumpulkan dari daerah sebaran asli (provenan).

5. Kebun Benih Semai (KBS), yaitu sumber benih yang dibangun dari biji berasal dari pohon plus (pohon pilihan yang berpenampilan bagus).

6. Kebun Benih Klon (KBK), yaitu sumber benih yang dibangun dari bahan vegetatif (selain biji misal: batang, daun atau akar) dari pohon plus.

7. Kebun Benih Pangkas (KP), yaitu sumber bahan vegetatif (untuk setek atau kultur jaringan) yang dibangun dari bahan generatif (biji) atau vegetatif dari pohon yang berasal dari KBK atau KBS.

Dari sumber benih di atas, yang disebut lebih belakangan memiliki kualitas benih yang lebih bagus. 


\section{Bagaimana cara memilih pohon benih?}

- Pilih pohon berpenampilan unggul jika dibandingkan dengan pohon-pohon di sekitarnya, yaitu memiliki ciri:
a. diameter batang dan tinggi pohon di atas rata-rata,
b. batangnya lurus,
c. batang bebas cabangnya tinggi,
d. tajuknya (cabang beserta daun-daunnya) sehat dan seimbang,
e. bebas dari hama dan penyakit,
f. kualitas kayunya bagus (misal: bulat dan serat kayunya lurus),
g. telah dewasa dan mampu menghasilkan benih.

- Pada tegakan jati yang tidak seumur, hati-hati dalam menggunakan ukuran diameter dan tinggi pohon dalam memilih pohon benih.

- Pada tegakan yang tidak seumur, pohon yang memiliki diameter besar belum tentu menunjukkan kualitas yang unggul, tetapi mungkin karena umurnya lebih tua.

- Pada tegakan seumur, diameter dan tinggi pohon merupakan ciri yang penting dalam pemilihan pohon benih.

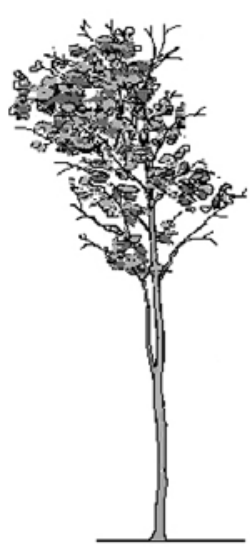

(A)

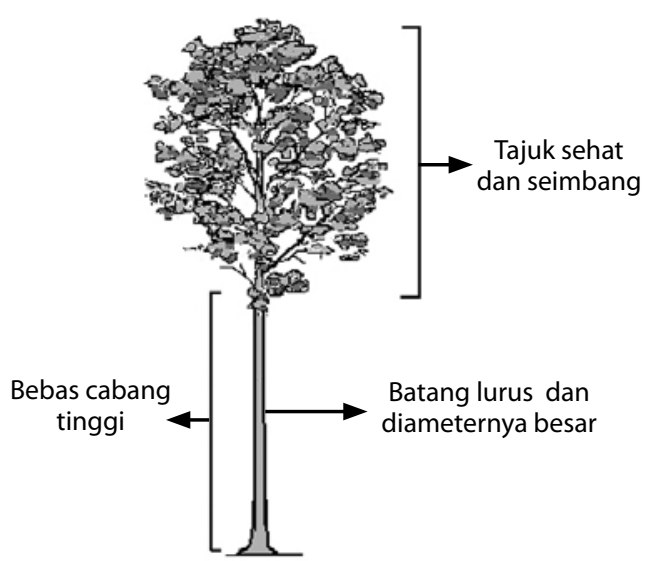

(B)

Gambar 3.3. Contoh cara memilih pohon benih

(A) pohon jati yang tidak layak menjadi pohon benih

(B) pohon jati yang dapat ditunjuk sebagai pohon benih 


\section{Bisakah memilih pohon benih dari kebun atau hutan di sekitar kita?}

Bisa, asal dapat memenuhi beberapa persyaratan berikut:

- Jangan memilih pohon benih yang tumbuh sendirian (di sekitarnya tidak ada pohon jati dewasa lainnya, jika ada pohon jati lain jaraknya lebih dari $100 \mathrm{~m}$ ), walaupun pohon tersebut besar dan lurus.

- Pohon yang tumbuh sendirian benihnya merupakan hasil penyerbukan sendiri, sehingga kemungkinan besar berkualitas buruk.

- Hindari memilih pohon benih dari kebun yang sebagian besar pohon jatinya berpenampilan buruk, abnormal, atau berpenyakit.

- Jika petani membangun kebun jati yang benihnya berasal dari satu pohon, maka sebaiknya tidak menunjuk pohon di kebun tersebut sebagai pohon benih, karena pohon-pohonnya berkerabat dekat, walaupun penampilannya bagus.

\section{Kapan dan bagaimana memanen benih?}

- Buah jati yang telah masak pada umumnya dapat dipanen pada bulan September - Oktober.

- Pohon induk hendaknya sudah cukup dewasa yaitu minimal pernah berbuah dua atau tiga kali.

- Pohon jati mulai menghasilkan benih pada umur 12-15 tahun. Pada pohon jati terubusan, pohon dapat menghasilkan benih pada umur yang lebih muda.

- Untuk meningkatkan kualitas benih, pengambilan benih dilakukan secara merata dari semua bagian tajuk (atas, samping, dan bawah), karena bagian-bagian ini mungkin terserbuki pada waktu atau oleh pohon induk yang berbeda.

- Bersihkan lantai hutan sekitar pohon induk. Hamparkan alas (terpal atau plastik) di lantai hutan di bawah tajuk pohon induk untuk menampung benih yang jatuh. 


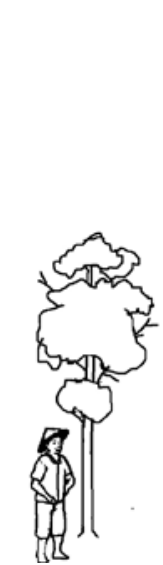

Satu pohon di kebun petani a

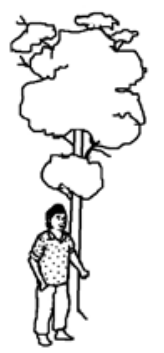

Satu pohon di kebun petani $b$

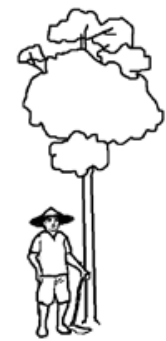

Satu pohon di kebun petani $\mathrm{c}$
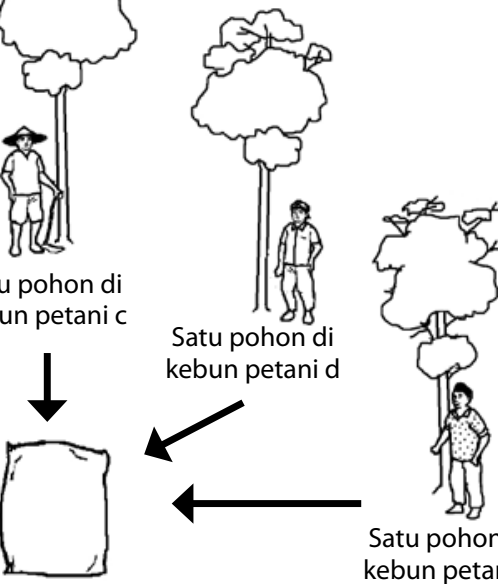
kebun petani d

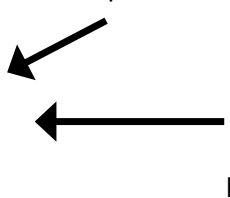

Satu pohon di kebun petani e

Benih dari lima pohon dari Kelompok Tani A

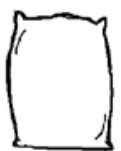

Benih dari lima pohon dari KelompokTani B

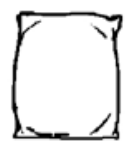

Benih dari lima pohon dari Kelompok Tani C
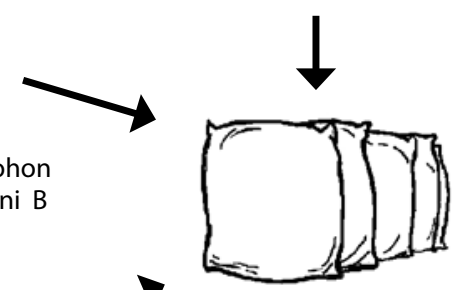

Campuran benih dari 25 pohon induk dari lima kelompok tani
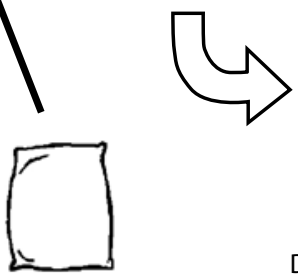

Benih dari lima pohon dari Kelompok Tani E
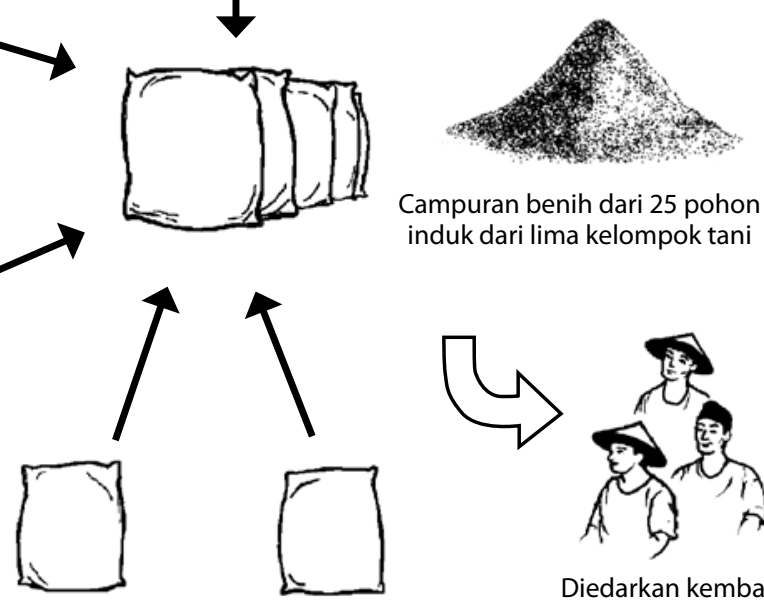

Benih dari lima pohon dari Kelompok Tani D

Gambar 3.4. Teknik pengumpulan benih bermutu melalui gabungan kelompok tani 
- Pohon dipanjat kemudian dahan digoyang-goyang. Benih yang telah masak akan berjatuhan di atas alas yang telah disediakan

- Disarankan untuk tidak mengumpulkan benih dari jatuhan alami, karena belum tentu berasal dari pohon terdekat (pohon benih yang dipilih).

- Pengumpulan benih di lantai hutan (dari jatuhan alami) boleh dilakukan pada tegakan benih, APB, atau kebun benih. Semua pohon pada tegakan ini dianggap sebagai pohon induk berkualitas, sehingga setiap benih merupakan hasil perkawinan dari pohon induk yang baik.

- Hindari memperoleh benih hanya dari satu pohon, walaupun pohon ini mampu menyediakan benih dalam jumlah yang mencukupi kebutuhan.

- Benih yang berasal dari satu pohon akan memiliki kualitas yang rendah. Benih ini jika ditanam bersamaan di dalam satu area akan menghasilkan hutan yang tidak tahan terhadap serangan wabah hama/penyakit dan perubahan iklim, serta tidak bisa digunakan sebagai sumber benih.

- Usahakan benih diperoleh dari minimal 10 pohon induk yang tidak berkerabat dekat (tidak memiliki sejarah dari induk yang sama). Lebih baik jika diperoleh dari 30-50 pohon.

- Untuk menghindari pengadaan benih dari induk yang berkerabat dekat, sebaiknya hanya dipilih satu pohon benih untuk setiap lahan yang dikelola oleh satu petani.

- Perlu kerjasama antar petani atau kelompok tani dalam mengumpulkan benih. Bila setiap kelompok tani memiliki lima pohon benih (dari lima lahan petani), maka dengan tukar menukar benih antar lima kelompok tani maka dapat diperoleh benih dari 25 pohon induk yang tidak berkerabat dekat. 


\subsection{Penanganan benih}

\section{Bagaimana menangani benih?}

- Pilihlah benih yang sehat dan telah masak. Benih jati yang telah masak dicirikan dengan warna coklat gelap. Buah yang belum masak berwarna agak putih terang.

- Benih dikeringkan dengan cara dijemur pada suatu areal datar untuk mendapatkan sinar matahari secara langsung.

- Penjemuran dilakukan selama 1-2 hari penuh pada cuaca cerah. Dengan cara ini akan dihasilkan benih dengan kadar air sekitar $12 \%$.

- Setelah kering, benih dibersihkan dengan cara mengupas mahkotanya, dan memisahkan kotoran atau serasah yang tercampur dalam benih.

- Benih yang sudah berlubang-lubang (bopeng) tidak selalu menandakan bahwa benih tersebut berkualitas buruk. Benih seperti ini sering lebih mudah berkecambah karena telah mengalami skarifikasi (penipisan kulit benih) secara alami.

- Di dalam satu kg benih jati biasanya berisi sekitar 1.500 butir. Ukuran besar atau kecil tidak menunjukkan baik atau buruknya mutu suatu benih.

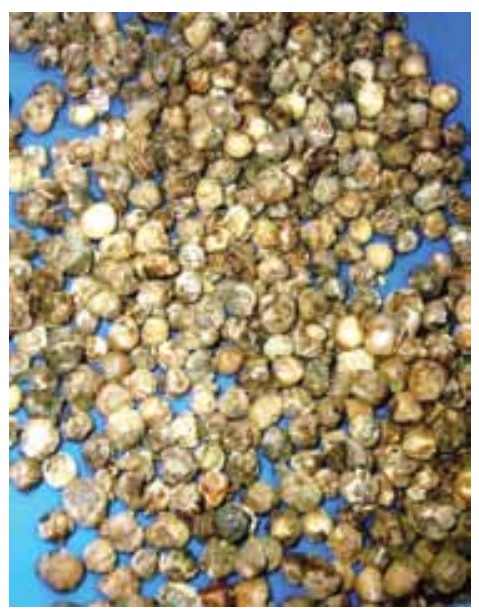

Gambar 3.5. Benih bopeng, yang telah mengalami penipisan kulit secara alami

\section{Bagaimana menyimpan benih?}

- Benih yang telah kering disimpan dalam wadah plastik.

- Ruang simpan hendaknya kering dan sejuk. Jika memungkinkan gunakanlah ruangan ber-AC.

- Benih sebaiknya disimpan paling lama 2 tahun. 


\section{4 \\ Pembuatan Bibit}

\subsection{Bibit dari benih}

\section{Bagaimana cara mengecambahkan benih?}

- Benih jati merupakan jenis benih yang sulit berkecambah, karena kulit benihnya sulit ditembus oleh air dan udara yang merupakan syarat utama untuk perkecambahan.

- Agar benih jati cepat berkecambah, diperlukan kondisi dan perlakuan tertentu yang bisa melunakkan kulit benih agar udara dan air dapat masuk ke dalam benih.

- Upaya yang dilakukan sebelum penaburan, agar benih cepat berkecambah, dikenal sebagai perlakuan pendahuluan.

\section{Bagaimana perlakuan pendahuluannya?}

- Benih disterilkan (dibebaskan dari hama dan penyakit) terlebih dahulu dengan cara dijemur sampai kering.

- Pilih salah satu cara perlakuan pendahuluan berikut ini:

a. Benih direndam selama $3 \times 24$ jam dalam air mengalir, kemudian tiriskan benih selama 2 hari.

b. Benih direndam selama 3 hari dalam air tergenang yang selalu diganti setiap hari, kemudian tiriskan benih selama 2 hari.

c. Benih direndam dalam air dingin selama satu hari, kemudian benih dikeringkan dengan dijemur di bawah terik matahari satu hari. Hal tersebut diulang kurang lebih selama 4-5 hari. 
d. Benih setiap hari direndam dalam air dingin selama satu jam kemudian dipindah ke dalam air panas selama 1 jam selanjutnya dikering-anginkan. Hal ini dilakukan selama 1 minggu.

e. Benih direndam dalam larutan Asam Sulfat pekat $\left(\mathrm{H}_{2} \mathrm{SO}_{4}\right)$ selama 15 menit, kemudian dicuci dengan menggunakan air, dan tiriskan selama 1 malam.

f. Benih direndam dalam air dingin selama dua malam kemudian dijemur di bawah sinar matahari selama 1 hari.

- Cara-cara tersebut di atas bisa pula dikombinasikan antara teknik satu dengan teknik lainnya sehingga diperoleh keberhasilan semai benih yang maksimal.

\section{Bagaimana cara menyemaikannya?}

- Siapkan media tabur yaitu pasir. Pasir yang baik tidak terlalu kasar atau terlalu halus serta tidak banyak tercampur tanah.

- Media disterilkan dengan cara dijemur sampai kering dan dicampur nematisida (racun pembunuh cacing).

- Kemudian media tabur disiram air secara merata.

- Benih yang telah diberi perlakuan pendahuluan dimasukkan ke media tabur, dengan posisi bekas tangkai buah menghadap ke bawah.

- Benih ditanam sedalam diameter benih, kemudian ditaburi pasir sehingga punggung benih terbenam sekitar $1-2 \mathrm{~cm}$ di dalam media.

- Media ditutup dengan selapis jerami agar media tidak hanyut ketika disiram air (Lihat Gambar 4.1).

- Media disiram air.

- Bedeng/bak tabur ditutup sungkup plastik, namun jika suhu sudah tinggi (misalnya cuaca cerah di musim kemarau) maka sungkup tidak diperlukan.

- Bedeng tabur dipelihara dengan selalu dibersihkan dari gulma dan disiram setiap hari agar media tidak sampai kering. 


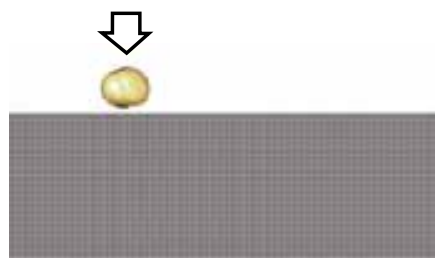

1

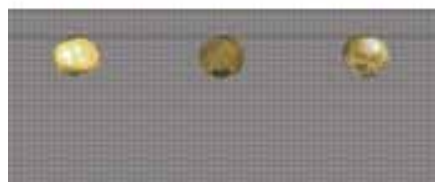

3

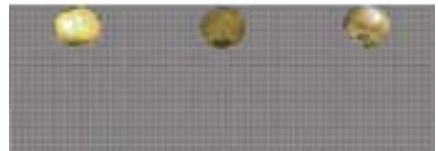

2

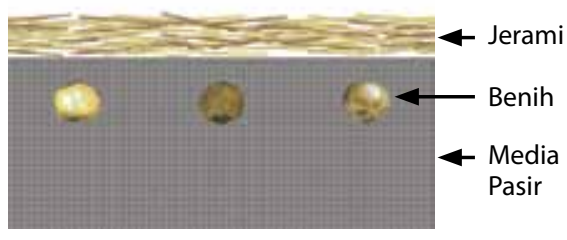

4

Gambar 4.1. Teknik penanaman benih pada media tabur

- Setelah lima sampai tujuh hari sejak penaburan, maka benih di media tabur akan mulai berkecambah. Perkecambahan biasanya tidak serentak, karena masih bisa dijumpai benih yang berkecambah pada hari ke 100 .

\section{Bagaimana menyapih kecambah?}

- Siapkan media semai berupa campuran tanah humus (tanah lapisan atas) dan kompos dengan perbandingan 2:1; atau pupuk kandang dan tanah humus (2:3); atau kompos, tanah humus, dan sekam padi $(2: 1: 1)$.

- Media dijemur dan dicampur dengan fungisida (racun pembunuh jamur) agar steril, kemudian ditempatkan pada kantong semai.

- Kecambah siap disapih setelah berumur 3-5 hari atau dicirikan dengan terbentuknya sepasang daun muda yang belum membuka penuh (Lihat Gambar 4.2). 


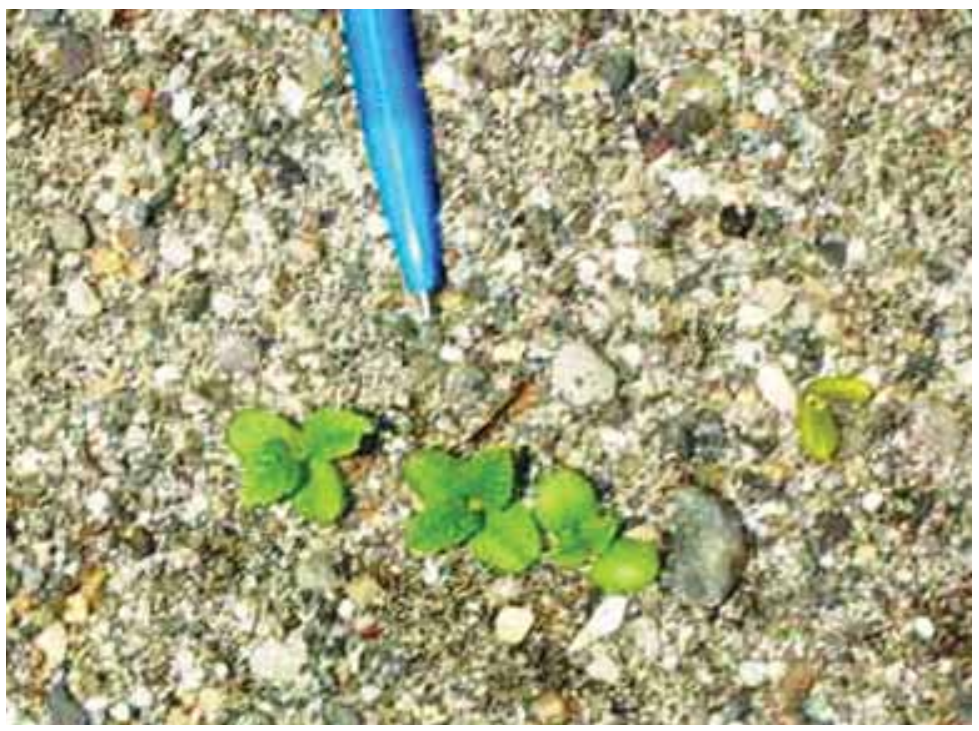

Gambar 4.2. Kecambah yang telah siap disapih

- Penyapihan dapat dilakukan pada waktu pagi (sebelum jam 10.00) atau sore (sesudah jam 15.00).

- Untuk memudahkan penyapihan, media dibasahi terlebih dahulu.

- Media di sekitar dan di bawah kecambah diangkat dengan menggunakan ranting atau bambu berbentuk pipih untuk mengambil kecambah beserta akar-akarnya.

- Angkat kecambah dengan memegang daun atau lembaganya, kemudian langsung ditanam pada media tanam yang telah dibasahi dan dilubangi.

- Jika kecambah yang disapih jumlahnya banyak, kecambah tidak langsung ditanam tetapi bisa ditampung dahulu di dalam wadah berisi air.

- Siram media dan benih dengan pancaran air yang halus. 


\subsection{Bibit dari setek pucuk}

\section{Dari mana bahan setek diperoleh?}

- Bahan setek yang berupa pucuk dapat diperoleh dari terubusan, bibit, atau kebun pangkas.

- Sumber setek tersebut hendaknya dari pohon yang berkualitas bagus atau klon terpilih.

\section{Apakah klon itu?}

Klon adalah sekumpulan pohon atau bibit yang berkualitas genetik (kualitas yang diturunkan dari induknya) sama persis, karena merupakan hasil perbanyakan vegetatif (pembibitan tidak menggunakan benih) dari satu batang pohon. Pembibitan untuk memperbanyak klon dilakukan melalui setek, cangkok, okulasi, atau kultur jaringan.
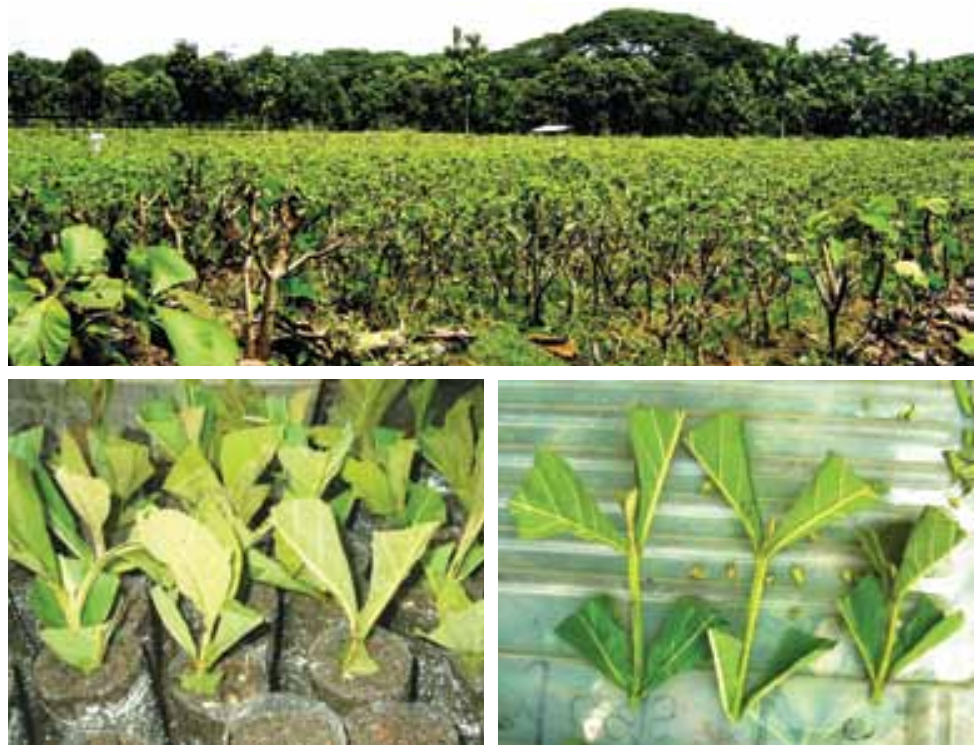

Gambar 4.3. Kebun pangkas jati, bahan setek pucuk jati dan penanamannya 


\section{Bagaimana memilih dan menyiapkan bahan tanaman untuk setek?}

- Bahan setek berupa pucuk yang berumur 2-3 minggu yang memiliki ciri-ciri: batang masih berbulu, agak silindris, warna hijau cerah, memiliki tiga pasang daun, panjang antara $5-7 \mathrm{~cm}$.

- Pilih pucuk yang tumbuh tegak ke atas (tunas orthotroph), hindari tunas yang tumbuh menyamping.

- Setelah pucuk diambil, tiap helai daun dipotong dan disisakan $1 / 3$ nya.

- Pangkal setek pucuk dipotong miring dengan pisau tajam (cutter).

- Pangkal setek dicelupkan dalam larutan Indole Butyric Acid (IBA) selama 5-10 menit. Konsentrasi IBA yang dipakai adalah 0,02 gr IBA yang dilarutkan dalam sekitar 2 sendok $\mathrm{NaOH}$ atau alkohol kemudian dicampur air menjadi 1 liter.

\section{Bagaimana cara menanam setek?}

- Siapkan media yang berupa campuran pasir, kompos dan tanah lapisan atas dengan perbandingan 2:3:1, yang dimasukkan ke dalam polibag berukuran $10 \times 15 \mathrm{~cm}$.

- Polibag sebaiknya bening (tembus pandang) agar dapat diketahui jika akar telah tumbuh.

- Polibag ditata di dalam bedeng berupa tanah rata yang tidak tergenang air jika bibit disiram. Bedeng semai sebaiknya berada pada area yang ternaungi (di bawah tegakan atau paranet/ shading net).

- Agar pangkal setek tidak terluka ketika ditanam maka media dalam polibag dilubangi terlebih dahulu dengan menggunakan ranting.

- Setek yang telah dicelupkan dalam larutan IBA ditanam pada lubang tersebut.

- Media disiram dengan air.

- Bedeng setek ditutupi sungkup plastik dengan ketinggian sungkup $\pm \frac{1}{2}$ m (Gambar 4.4). 


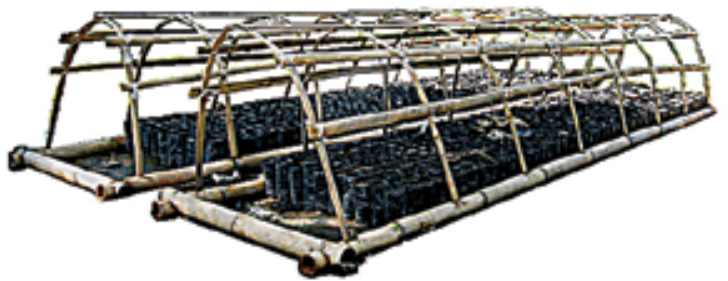

1 Buat rangka sungkup dari bambu, kemudian polibag ditata di dalamnya

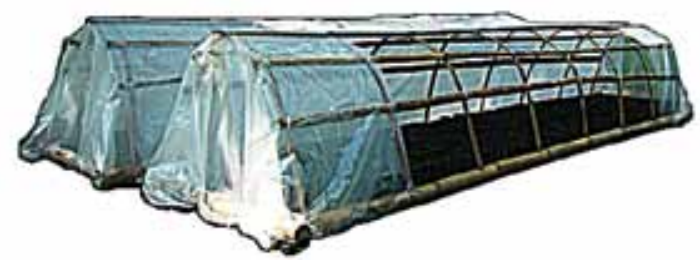

2 Kedua ujung rangka ditutup rapat dengan plastik

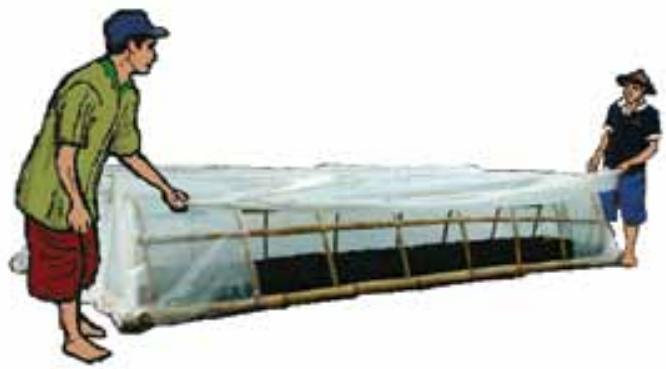

3 Tutup dengan plastik yang bisa dibuka tutup

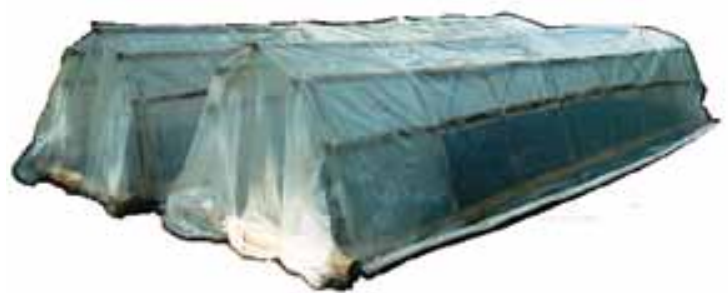

4 Sungkup plastik transparan yang tertutup rapat dapat menjaga kelembaban bedeng setek tetap tinggi

Gambar 4.4. Teknik pembuatan sungkup plastik untuk bedeng setek 
- Kondisi lingkungan yang baik untuk perakaran setek jati adalah: kelembaban di atas $80 \%$ dan suhu berkisar antara $24-32^{\circ} \mathrm{C}$.

- Selama pemeliharaan, penyiraman dilakukan dua kali sehari, yaitu pada pagi dan sore hari.

- Jika terjadi gejala adanya serangan jamur, semprot setek dengan fungisida (racun pembasmi jamur).

\section{Bagaimana penanganan setek setelah berakar?}

Sebelum ditanam di lapangan, setek harus secara bertahap dibiasakan untuk hidup di lingkungan kering dan terbuka yang berbeda dengan kondisi di sungkup. Caranya adalah:

- Setek yang berakar dipisahkan dan dikumpulkan dalam satu bedeng tersendiri. Bedeng ini masih berada pada area ternaungi.

- Setek yang belum berakar juga dikumpulkan dalam bedeng lainnya untuk dilanjutkan proses perakarannya.

- Setek yang berakar dibiarkan beradaptasi pada bedeng yang baru dengan sungkup tertutup selama 3 hari.

- Sungkup dibuka secara bertahap diawali dengan dibuka $10 \mathrm{~cm}$. Setiap hari sungkup dibuka lebih lebar $\pm 10 \mathrm{~cm}$, terus menerus hingga pada umur 2 minggu sungkup telah terbuka penuh.

- Biarkan bibit setek pada area ternaungi tanpa sungkup selama 2 minggu.

- Selanjutnya bibit hasil biakan setek ini dipindah ke area terbuka hingga siap tanam.

\subsection{Bibit dari sumber lainnya}

\section{Adakah cara pengadaan bibit lainnya?}

Ada, yaitu bibit dari anakan alami dan dari stump. Ada beberapa cara lain lagi yang membutuhkan teknologi dan biaya tinggi untuk membibitkan jati, antara lain dengan kultur jaringan. 


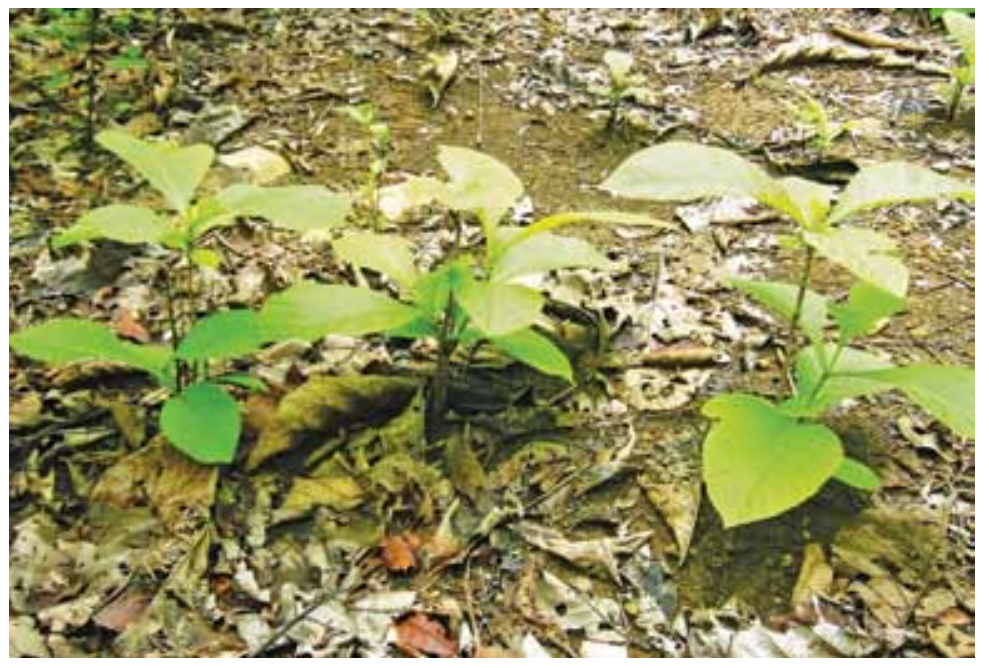

Gambar 4.5. Anakan alami yang dapat dijumpai di kebun jati

\section{Bagaimana cara menyiapkan bibit dari anakan alami?}

- Bahan cabutan diambil dari anakan yang tumbuh rapat di areal tanaman jati.

- Bibit yang siap dipindahkan adalah yang sudah mempunyai 2-3 pasang daun, berdaun sehat, berbatang lurus dan seimbang.

- Anakan ini dicabut pada musim hujan, daun dikurangi separuhnya dan sebagian akar tunggangnya dipotong, kemudian langsung ditanam di polibag.

- Setelah berumur 3-4 bulan di persemaian, bibit siap ditanam.

\section{Apakah stump itu?}

- Stump adalah bibit yang berasal dari semai yang telah dihilangkan seluruh daun dan bulu-bulu akarnya sehingga yang tersisa hanya sebagian batang dan sebagian akar utama. 
- Stump dapat digunakan untuk memindahkan bibit atau anakan alami yang sudah cukup besar dengan diameter batang 2-3 cm.

- Stump juga dapat digunakan untuk mempermudah pengiriman bibit, karena lebih ringan dan ringkas ketika dikirimkan.

\section{Bagaimana cara membuat stump?}

- Bibit atau anakan dicabut dan pertahankan agar akar masih cukup panjang.

- Batang dan akar tunggang dipotong. Batang disisakan sekitar 3-4 cm dan akar disisakan sekitar $15-20 \mathrm{~cm}$. Bulu-bulu akar juga dipotong.

- Untuk pengiriman, stump dibungkus dengan bahan yang lembap, misalnya pelepah pisang.

- Sebelum ditanam di lapangan, tumbuhkan dahulu stump di polibag dan tempatkan pada lingkungan yang ternaungi.

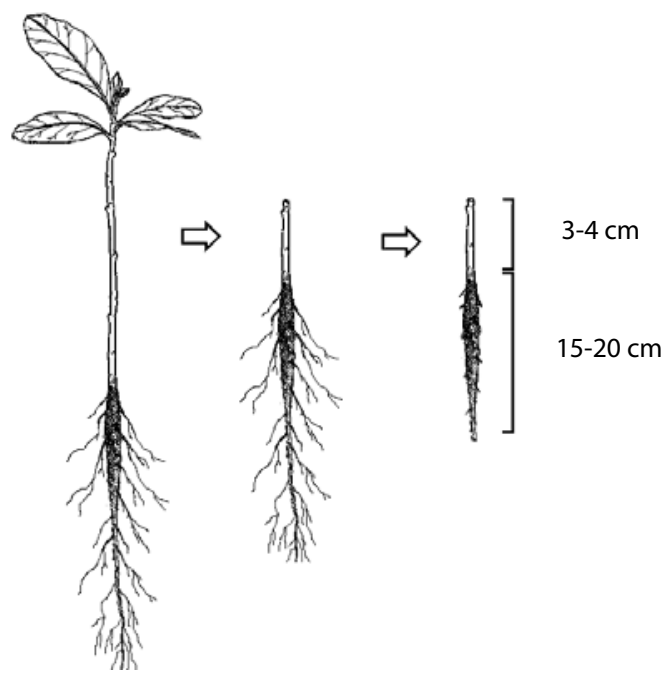

Gambar 4.6. Cara membuat stump jati 
- Jika dari stump tumbuh tunas lebih dari satu, pilihlah salah satu tunas yang tumbuhnya paling baik untuk dijadikan batang utama. Tunas-tunas yang lain dipangkas.

- Bibit siap ditanam setelah daun dan akar tumbuh baik dan kuat.

\section{Bagaimana cara memelihara bibit di persemaian?}

- Kegiatan pemeliharaan yang dilakukan meliputi penyiraman, pemupukan, penyiangan, pemangkasan (pewiwilan), pemotongan akar yang keluar dari polibag, penjarangan, dan pemberantasan hama penyakit.

- Penyiraman dilakukan dua kali sehari pada pagi dan sore hari, atau minimal satu kali sehari di sore hari.

- Pemupukan dilakukan pada umur 1 bulan setelah penyapihan dengan menggunakan pupuk NPK, dan diulang pada umur 2 bulan, dengan dosis 2 gr per bibit (sekitar $1 / 2$ sendok teh) setiap pemupukan.

- Penyiangan dilakukan dengan membersihkan gulma yang berada di dalam polibag maupun yang berada di sela-sela antar polibag.

- Pemangkasan dilakukan setelah bibit berketinggian $\pm 20 \mathrm{~cm}$ dengan membuang daun-daun tua, kering, busuk, atau berpenyakit, dan sisakan tiga pasang daun teratas.

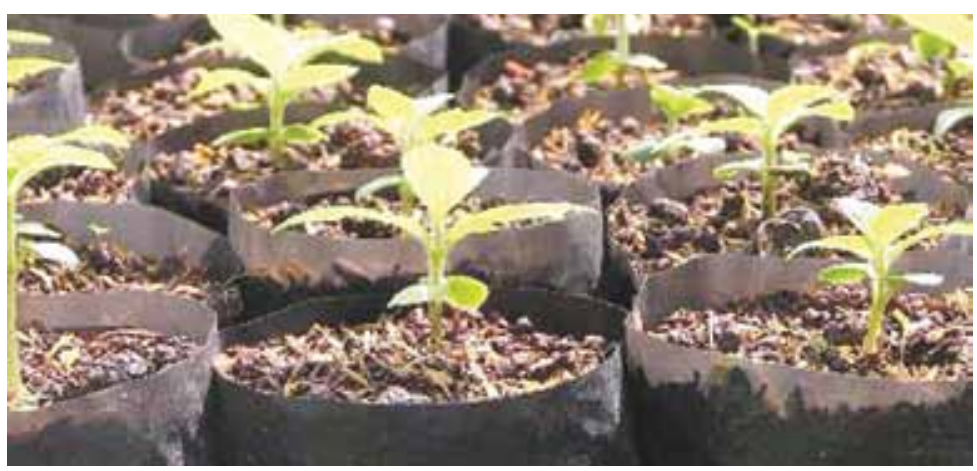

Gambar 4.7. Bibit jati muda di persemaian 
- Akar yang keluar dari polibag dipotong secara rutin agar akar tidak menembus ke dalam tanah. Pemotongan terakhir minimal 1-2 minggu sebelum bibit didistribusikan.

- Jarak antar bibit perlu dijarangkan apabila antar bibit sudah saling bersinggungan atau daunnya saling menutupi.

- Pemberantasan hama penyakit akan diterangkan lebih rinci pada Bagian 6.

\section{Bagaimana ciri bibit yang baik dan siap tanam?}

Diameter batang dan tinggi bibit tidak bisa dijadikan acuan untuk menentukan kualitas bibit.

Ciri bibit yang berkualitas baik dan siap tanam adalah:

- Media sarang dan akarnya kuat mengikat media. Ciri-cirinya adalah jika bibit dicabut dari polibag maka media dan akar akan membentuk gumpalan yang utuh namun berpori/tidak keras padat.

- Batang tunggal, kokoh, dan sudah berkayu. Bibit tumbuh tegak, antara diameter dan tinggi tampak seimbang.

- Pucuk sehat, daun segar, dan tidak terserang hama atau penyakit.

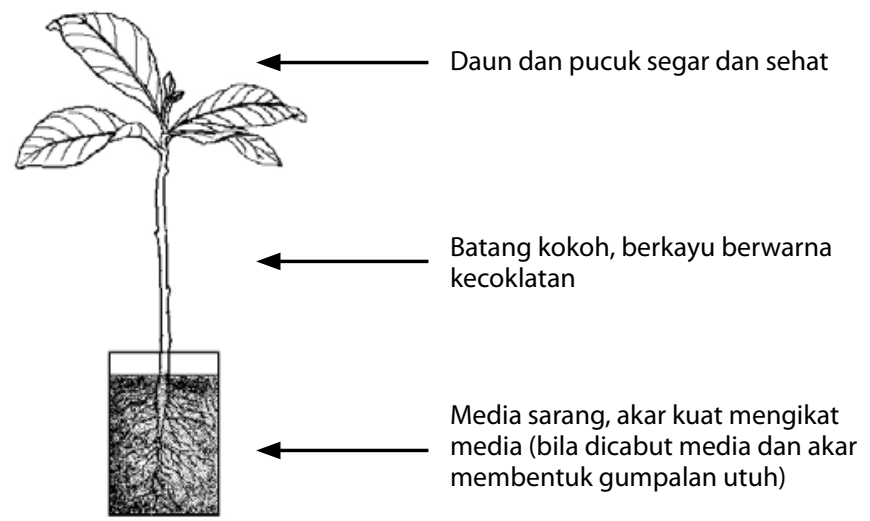

Gambar 4.8. Ciri-ciri bibit yang baik dan siap untuk ditanam 


\section{Penanaman}

\subsection{Perancangan pola tanam}

\section{Bagaimana pola penanaman jati yang sebaiknya dilakukan oleh petani?}

- Beberapa pola tanam yang bisa dikembangkan adalah monokultur (tanaman sejenis), campuran, dan tumpangsari.

- Penentuan pola tanam jati ini hendaknya mempertimbangkan kondisi lahan dan tujuan penggunaan lahan.

- Pada lahan subur, pengembangan hutan jati sebaiknya menggunakan pola tanam tumpangsari, karena dapat memaksimalkan keuntungan dari pemanfaatan lahan. Selain kayu, petani juga memperoleh keuntungan dari hasil pertanian.

- Pada tanah tidak subur, berbatu-batu, dan miring sebaiknya dimanfaatkan untuk pola monokultur atau campuran, sehingga penanaman pohon juga bertujuan untuk memperbaiki kualitas tanah serta mencegah tanah longsor dan erosi.

- Untuk menambah keanekaragaman produk agar dapat diperoleh pendapatan jangka pendek, menengah, dan jangka panjang sebaiknya pola yang dikembangkan adalah campuran atau tumpangsari.

- Jika lokasi lahan jauh dari tempat tinggal, atau pemilik lahan tidak memiliki cukup tenaga kerja untuk melakukan kegiatan pemeliharaan rutin, maka pola tanam monokultur, atau campuran lebih tepat dibanding dengan memilih pola tumpangsari. 


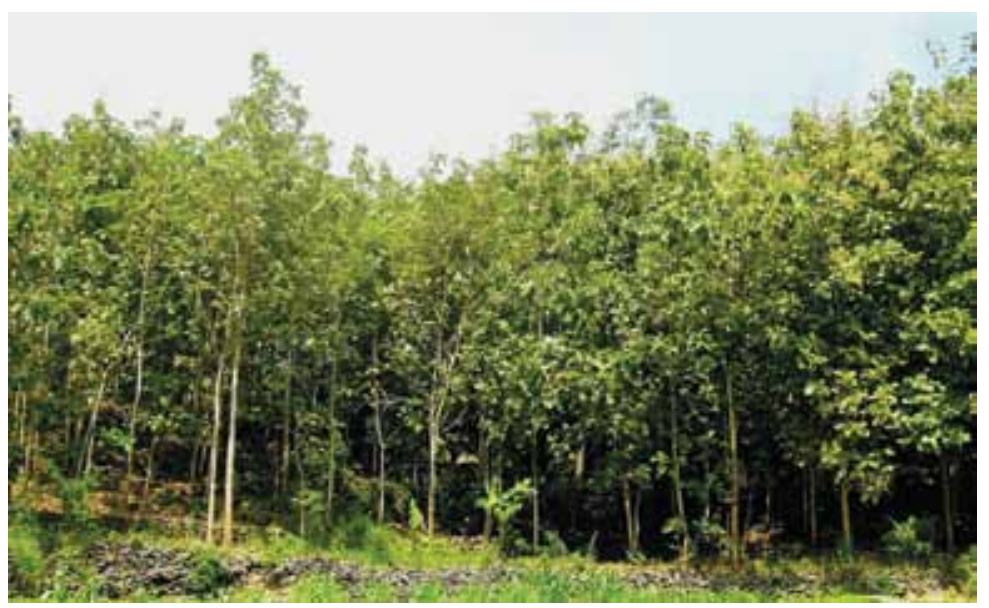

Gambar 5.1. Hutan jati rakyat dikelola dengan pola tanam monokultur

\section{Bagaimana pola penanaman monokultur?}

- Pada pola monokultur hanya terdapat satu jenis tanaman saja yang ditanam.

- Pola ini sering dipilih jika pemilik lahan kurang membutuhkan sumber penghasilan lainnya, misalnya untuk tanaman pertanian, atau tidak memiliki cukup tenaga kerja untuk mengelola lahan secara intensif.

- Alasan lainnya adalah, pemilik mempunyai lahan yang luas atau mempunyai pekerjaan dan/atau sumber pendapatan lain yang cukup untuk memenuhi kebutuhan rumah tangga.

\section{Apa kelebihan dan kelemahan pola tanam monokultur?}

- Keuntungan pola ini adalah dengan luasan yang sama akan diperoleh volume kayu yang lebih banyak, kualitas yang lebih baik dan seragam dibandingkan dengan pola penanaman campuran atau tumpangsari.

- Pengelolaan juga lebih mudah karena jenis tanamannya seragam. 
- Pola ini memiliki kelemahan, yaitu apabila terjadi serangan hama dan penyakit, penyebarannya lebih mudah meluas.

- Karena kebutuhan haranya sama, maka persaingan antar pohon untuk mendapatkan hara pada pola monokultur lebih tinggi dari pada pola campuran.

\section{Apa yang dimaksud pola penanaman tumpangsari?}

- Sistem penanaman tumpangsari adalah penanaman jati (tanaman pokok) yang dikombinasikan dengan tanaman pertanian/ semusim di dalam satu area.

- Di masyarakat, pola ini dapat diterapkan di lahan tegalan atau di pematang sawah.
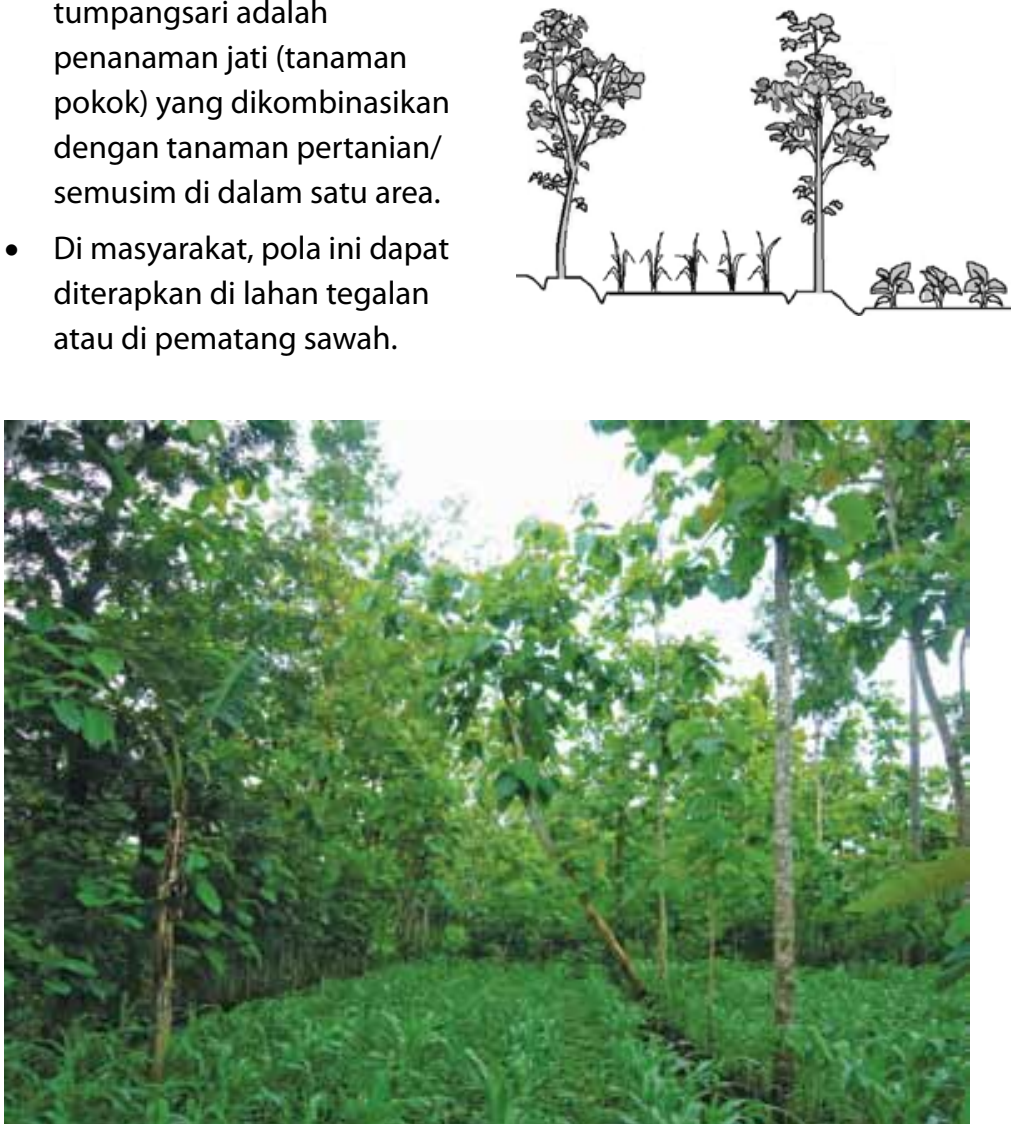

Gambar 5.2. Jati yang dikelola secara tumpangsari di Gunungkidul 
- Keuntungan dari sistem tumpangsari adalah disamping mendapatkan hasil kayu, petani juga memperoleh hasil jangka pendek, berupa panen dari tanaman yang ditumpangsarikan, seperti jagung, kacang tanah, singkong, talas, nilam, dan emponemponan (kunir, jahe, temuireng, dll).

- Kegiatan pengolahan tanah dan pemupukan ketika merawat tanaman semusim berpengaruh baik terhadap pertumbuhan jati. Pemangkasan akar jati yang terjadi ketika pengolahan tanah menurut pengalaman petani juga memacu pertumbuhan pohon jati.

- Sebaiknya hindari tumpangsari dengan tanaman suku Solanaceae (terong-terongan) ketika jati masih muda. Tanaman ini bisa menjadi sarana penularan (inang) penyakit layu (keterangan lebih lengkap lihat Bagian 6).

- Pola tumpangsari juga dapat dikombinasikan dengan tanaman perkebunan (misal: kakao atau kelapa sawit).

\section{Apa yang dimaksud dengan hutan campuran?}

Hutan campuran adalah lahan yang ditanami berbagai jenis pepohonan, baik seumur maupun tidak seumur yang memiliki ciri-ciri sebagai hutan.

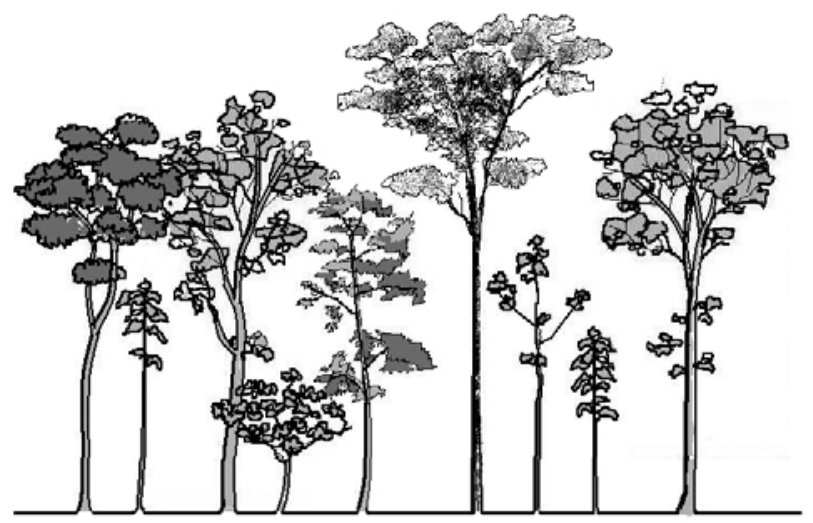

Gambar 5.3. Hutan dengan pola tanam campuran 


\section{Apa kelebihan dan kelemahan hutan campuran?}

- Hutan campuran terdiri dari beberapa jenis pohon dengan masa tebang yang sama atau berbeda, dan memiliki tinggi tajuk yang berbeda. Pola tanam seperti ini memiliki kelebihan, antara lain:
a. lebih tahan terhadap gangguan hama penyakit,
b. penggunaan ruang tumbuh maupun sistem perakarannya lebih baik,
c. variasi lahan dapat dimanfaatkan secara maksimal,
d. lebih tahan terhadap terpaan angin, dan
e. selain untuk tujuan produksi juga cocok untuk perbaikan kualitas lahan dan lingkungan.

- Perbedaan daur tebang dan/atau kombinasi dengan tanaman penghasil produk non-kayu menambah keanekaragaman (diversifikasi) penghasilan untuk jangka pendek, menengah, dan panjang.

- Pola ini dapat menghasilkan produk yang lebih mampu mengikuti perbedaan atau perubahan permintaan pasar.

- Pola tanam ini memiliki kelemahan, antara lain, jika bibit jati ditanam berdampingan dengan tanaman yang tumbuh cepat (misal akasia, sengon) maka tanaman jati akan kalah bersaing untuk mendapatkan makanan dan cahaya, sehingga pertumbuhan jati bisa terhambat.

- Karena masa tebang yang berbeda, jika tidak dilakukan secara hati-hati maka penebangan akan merusak tanaman lain di sekitarnya.

\section{Jenis-jenis tanaman apa yang sebaiknya dikombinasikan dengan jati di hutan campuran?}

Pemilihan jenis pohon yang akan dikombinasikan dengan jati disesuaikan dengan tujuan penanaman dan kondisi lahan.

- Agar dapat tumbuh dengan baik, dipilih jenis-jenis pohon yang sesuai dengan iklim dan kondisi lahannya. Misal: 
- pada daerah dataran tinggi, pohon yang ditanam bersamaan dengan jati hendaknya adalah jenis-jenis yang cocok di tempat tinggi, misalnya: mindi (Melia azedarach), waru gunung (Hibiscus macrophyllus), atau suren (Toona sp), sedangkan pada lahan yang beriklim kering dapat dikombinasikan dengan tanaman yang dapat tumbuh baik di tempat kering, misal cendana (Santalum album) (Lihat Tabel 5.1).

- pada lahan yang relatif subur bisa dikombinasikan dengan tanaman yang tumbuh cepat, seperti sengon (Paraserianthes falcataria), gmelina (Gmelina arborea), atau jenis lainnya.

- Untuk berjaga-jaga terhadap berbagai macam kebutuhan, dan untuk menghasilkan pendapatan jangka menengah dan panjang, perlu dipertimbangkan susunan jenis yang akan ditanam berdasarkan produk dan masa tebangnya. Jati dapat ditanam bersamaan dengan salah satu atau beberapa jenis pohon seperti:

- pohon lambat tumbuh lainnya (mahoni, sonokeling), untuk berjaga-jaga terhadap perubahan kebutuhan pasar.

- pohon cepat tumbuh (sengon, gmelina), untuk menyediakan kebutuhan jangka menengah.

- penghasil buah buahan dan sayuran (mangga, durian, petai, melinjo, kemiri), untuk mendapatkan penghasilan jangka pendek (bulanan atau tahunan).

- pakan ternak dan kayu bakar (tayuman/Bauhinia purpurea, lamtoro/Leucaena leucocephala, kaliandra/Caliandra calothyrsus, gamal/gliriside/Gliricidia sepium), atau

- penghasil komoditi non kayu lainnya (misal cendana).

- Untuk tujuan menjaga dan memperbaiki kualitas lahan dan lingkungan perlu dipertimbangkan komposisi jenis, berdasarkan tinggi rendahnya tajuk dan manfaatnya terhadap lahan. Misal:

- jenis-jenis yang dapat menyuburkan tanah (jenis polongpolongan: lamtoro, turi),

- memiliki akar yang dalam untuk menahan longsor (misal: kemiri, petai, mahoni), atau

- hindari jenis-jenis pohon yang rakus air (misal: pinus). 
- Selain variasi jenis, jika jati difungsikan sebagai tabungan untuk keperluan mendadak, maka pohon jati dapat dirancang agar memiliki umur yang berbeda sehingga kebutuhan bisa dipenuhi secara berkelanjutan dengan penerapan pola tebang pilih.

Tabel 5.1. Kesesuaian jenis-jenis pohon dengan tempat tumbuh (ketinggian tempat dan curah hujan)

\begin{tabular}{|c|c|c|}
\hline $\begin{array}{l}\text { Ketinggian } \\
\text { tempat } \\
\text { (m dpl) }\end{array}$ & $\begin{array}{l}\text { Iklim kering } \\
\text { (Curah hujan < } 2000 \\
\mathrm{~mm} / \mathrm{thn} \text { ) }\end{array}$ & $\begin{array}{l}\text { Iklim basah } \\
\text { (Curah hujan > } 2000 \\
\text { mm/thn) }\end{array}$ \\
\hline $\begin{array}{l}\text { Dataran } \\
\text { rendah } \\
(<350)\end{array}$ & $\begin{array}{l}\text { Akor, alpukat, bayur, beringin, } \\
\text { cemara laut, durian, gamal, } \\
\text { gmelina, hantap, huru, } \\
\text { jambu biji, jarak pagar, } \\
\text { jeruk bali, johar, kedaung, } \\
\text { kemiri, kelapa, kepel, keranji, } \\
\text { lamtoro, mahoni, mangga, } \\
\text { matoa, mimba, mindi, } \\
\text { nangka, pepaya, pulai, } \\
\text { rambutan, randu, salak, } \\
\text { sirsak, sonokeling, suren, } \\
\text { tayuman/kupu-kupu, tisuk/ } \\
\text { waru gunung, trembesi, turi }\end{array}$ & $\begin{array}{l}\text { Akor, asem, beringin, bungur, } \\
\text { durian, gmelina, hantap, } \\
\text { huru, jabon, jarak, kemiri, } \\
\text { kihiang, mahoni, mangium, } \\
\text { mindi, nangka, pepaya, pulai, } \\
\text { salak, saninten, sengon, } \\
\text { sirsak, sukun, sungkai, suren, } \\
\text { trembesi, turi, ulin }\end{array}$ \\
\hline $\begin{array}{l}\text { Dataran } \\
\text { medium } \\
(350-700)\end{array}$ & $\begin{array}{l}\text { Akor, alpukat, aren, beringin, } \\
\text { durian, gamal, gmelina, } \\
\text { hantap, huru, jarak pagar, } \\
\text { jambu biji, jambu mente, } \\
\text { jeruk, johar, kaliandra, kapok, } \\
\text { kedaung, kedondong, } \\
\text { kemiri, kelapa, kayu afrika, } \\
\text { keranji, kelapa, lamtoro, } \\
\text { lengkeng, mahoni, mangga, } \\
\text { mimba, mindi, nangka, } \\
\text { pepaya, picung, pinus, pulai, } \\
\text { rambutan, randu, rasamala, } \\
\text { sonokeling, suren, salak, } \\
\text { sukun, sirsak, tisuk, } \\
\text { trembesi, turi }\end{array}$ & $\begin{array}{l}\text { Akor, asem, alpukat, } \\
\text { beringin, bungur, belimbing, } \\
\text { cempedak, cempaka, } \\
\text { cengkeh, damar, delima, } \\
\text { durian, duku, gmelina, } \\
\text { huru, hantap, jabon, jarak, } \\
\text { jeruk, jambu air, jambu biji, } \\
\text { jengkol, kedondong, kelapa } \\
\text { sawit, kakao, kaliandra, karet, } \\
\text { kelapa, kemiri, kihiang, kopi } \\
\text { robusta, lengkeng, mahoni, } \\
\text { manggis, mangium, melinjo, } \\
\text { mindi, nangka, pepaya, } \\
\text { petai, pinus, pisang, pulai, } \\
\text { rambutan, rasamala, salak, } \\
\text { saninten, sawo, sengon, } \\
\text { sirsak, srikaya, sukun, } \\
\text { sungkai, suren, trembesi, } \\
\text { turi, ulin }\end{array}$ \\
\hline
\end{tabular}




\begin{tabular}{|c|c|c|}
\hline $\begin{array}{l}\text { Ketinggian } \\
\text { tempat } \\
\text { (m dpl) }\end{array}$ & $\begin{array}{l}\text { Iklim kering } \\
\text { (Curah hujan }<2000 \\
\text { mm/thn) }\end{array}$ & $\begin{array}{l}\text { Iklim basah } \\
\text { (Curah hujan > } 2000 \\
\mathrm{~mm} / \mathrm{thn})\end{array}$ \\
\hline $\begin{array}{l}\text { Dataran } \\
\text { tinggi } \\
(>700)\end{array}$ & $\begin{array}{l}\text { Alpukat, apel, aren, beringin, } \\
\text { gamal, gmelina, hantap, huru, } \\
\text { jambu biji, jarak pagar, jeruk, } \\
\text { johar, kaliandra, kayu afrika, } \\
\text { kedondong, kelapa, kemiri, } \\
\text { keranji, kesambi, kopi arabika, } \\
\text { lamtoro, lengkeng, mahoni, } \\
\text { mindi, mangga, manglid, } \\
\text { nanas, nangka, pepaya, } \\
\text { picung, pinus, pulai, randu, } \\
\text { rasamala, sukun, sirsak, suren, } \\
\text { terap, tisuk, trembesi, weru }\end{array}$ & $\begin{array}{l}\text { Asem, alpukat, beringin, } \\
\text { bungur, cengkeh, damar, } \\
\text { gmelina, huru, hantap, jabon, } \\
\text { jambu air, jambu biji, jarak, } \\
\text { jeruk, kaliandra, kedondong, } \\
\text { kemiri, kesambi, kesemek, } \\
\text { kihiang, kina, kopi arabika, } \\
\text { lengkeng, mahoni, mindi, } \\
\text { nangka, pepaya, pinus, pulai, } \\
\text { rasamala, saninten, sawo, } \\
\text { sengon, sirsak, srikaya, sukun, } \\
\text { suren, teh, trembesi, weru }\end{array}$ \\
\hline
\end{tabular}

Sumber: Badan Penelitian dan Pengembangan Pertanian (2006), Mindawati dkk. (2006), Soerianegara dan Lemmens (1994), dan dari berbagai sumber

\subsection{Persiapan lahan}

\section{Apa saja yang perlu dilakukan dalam persiapan lahan untuk penanaman jati?}

Kegiatan persiapan lahan antara lain meliputi: pemilihan lokasi, pembersihan lahan dari semak dan akar-akar gulma, pembongkaran tunggak, pembalikan tanah, penghancuran bongkahan tanah, dan penyingkiran batu.

\section{Mengapa persiapan lahan diperlukan?}

Persiapan lahan diperlukan agar lahan menjadi tempat tumbuh yang baik untuk jati. Pembersihan lahan dan pengolahan tanah antara lain berfungsi untuk mengurangi tumbuhan pengganggu (gulma), memperbaiki kualitas tanah. Pembersihan lahan juga ditujukan untuk mengurangi naungan, karena jati termasuk tumbuhan yang tidak tahan naungan. 


\section{Bagaimana memilih lahan yang cocok untuk jati?}

Secara alami pohon jati dapat tumbuh pada lahan-lahan yang berada di tepi pantai hingga daerah tinggi $(1.000 \mathrm{~m} \mathrm{dpl})$, beriklim kering maupun basah (curah hujan 1.250-3.000 mm/th), dan pada tanah berjenis regusol-grumosol. Namun, untuk mendapatkan tegakan jati yang menghasilkan kayu berkualitas tinggi, pilihlah lahan yang:

- memiliki kandungan kapur dan lempung-liat cukup tinggi,

- memiliki perbedaan musim kemarau dan musim penghujan yang nyata,

- berada pada ketinggian kurang dari $700 \mathrm{~m}$ dpl.

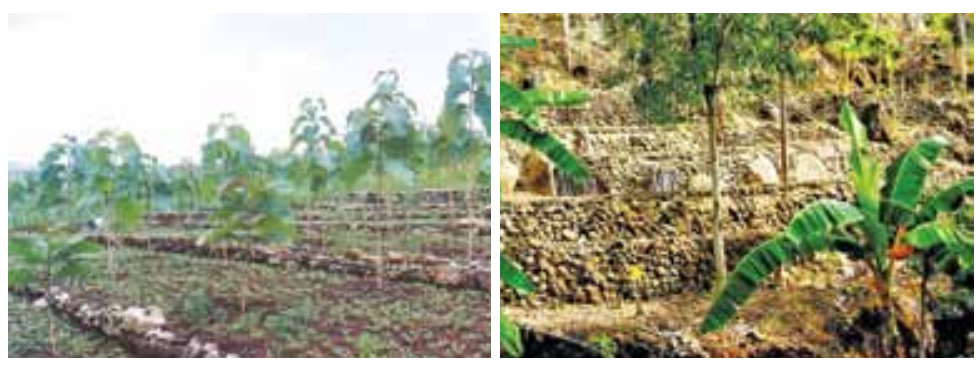

Gambar 5.4. Lahan terasering di Gunungkidul

\section{Tanah kami miring dan berbatu, bagaimana pengolahannya?}

- Tanah miring memiliki risiko terjadi longsor dan erosi sehingga lapisan tanah yang subur cepat terkikis atau hanyut, untuk itu sebaiknya dibuat terasering.

- Batu dimanfaatkan untuk pematang/penguat teras.

- Pada tanah yang banyak mengandung batu dapat dikembangkan pola hutan jati monokultur atau campuran. Dengan pola ini pengolahan tanah tidak sesering pola tumpangsari. 


\subsection{Penanaman}

\section{Apa saja kegiatan persiapan penanaman?}

Persiapan penanaman meliputi:

- Pengaturan jarak tanam,

- Pembuatan dan pemasangan ajir, dan

- Pembuatan lubang tanam.

\section{Berapa seharusnya jarak tanam jati?}

- Pada pola monokultur jarak tanam yang sering digunakan adalah 2,5 × 2,5 m; $3 \times 1 \mathrm{~m}$; $2 \times 3 \mathrm{~m}$; dan $3 \times 3 \mathrm{~m}$.

- Jarak tanam yang rapat akan menghasilkan batang yang lebih lurus dan pertumbuhan meninggi yang lebih cepat, sedangkan jarak tanam yang lebih lebar akan menghasilkan diameter batang yang lebih besar.

- Kombinasi yang baik adalah ditanam rapat pada awal penanaman agar pohon tumbuh tinggi lurus, kemudian dilakukan penjarangan agar batang tumbuh membesar.

- Pada sistem tumpangsari, jati dapat ditanam rapat dalam bentuk larikan. Antar larikan dibuat jarak yang lebih lebar untuk ditanami tanaman semusim, misalnya singkong, jagung, kedelai, kacang tanah, atau nilam.

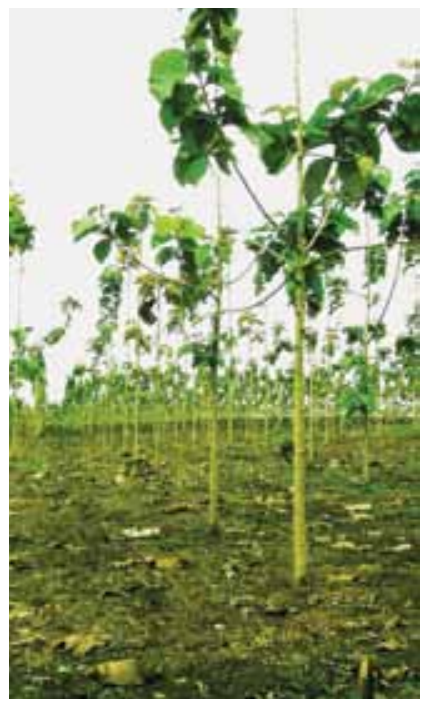

Gambar 5.5. Jati yang ditanam dengan jarak teratur

\section{Mengapa jarak tanam harus diatur?}

- Jarak tanam yang teratur akan memudahkan pemeliharaan dan pengawasan serta memberikan kesan rapi dan bersih.

- Memberi ruang yang cukup kepada pohon agar dapat memaksimalkan pertumbuhan tajuk, batang, dan akar. 
- Mengurangi persaingan antar pohon dalam mendapatkan air dan makanan (hara) dari dalam tanah sehingga pohon dapat tumbuh dengan maksimal.

- Mengurangi persaingan antar pohon dalam mendapatkan cahaya dan memperbaiki sirkulasi (pertukaran) udara sehingga batang dan tajuk tumbuh sehat.

- Mengurangi kemungkinan kerusakan pohon akibat terpaan angin yang kencang.

\section{Bagaimana jika kondisi lahannya tidak memungkinkan untuk dilakukan pengaturan jarak tanam?}

Untuk daerah-daerah tertentu, yang lahannya berbatu-batu atau lapisan tanahnya tipis, sering kali bibit tidak dapat ditanam dengan jarak teratur. Pada lahan seperti ini, kemampuan bibit untuk hidup juga kecil, sehingga penanamannya adalah:

- Jarak tanam boleh tidak teratur.

- Bibit ditanam dengan jarak tanam yang rapat (minimal $1 \mathrm{~m}$ ), pada tempat-tempat yang lapisan tanahnya memungkinkan bibit untuk tumbuh (kedalaman tanah minimal $20 \mathrm{~cm}$ ).

- Pada lahan seperti ini, bibit akan terseleksi secara alami. Bibit-bibit yang kuat atau ditanam pada tempat yang cocok akan dapat bertahan hidup.

- Setelah berumur sekitar 3-5 tahun, pohon-pohon yang tumbuh rapat dan tajuknya telah tumpang tindih dilakukan penjarangan, yaitu dengan cara mematikan tanaman yang penampilan atau pertumbuhannya buruk, hingga jarak tanamnya menjadi minimal $2 \mathrm{~m}$.

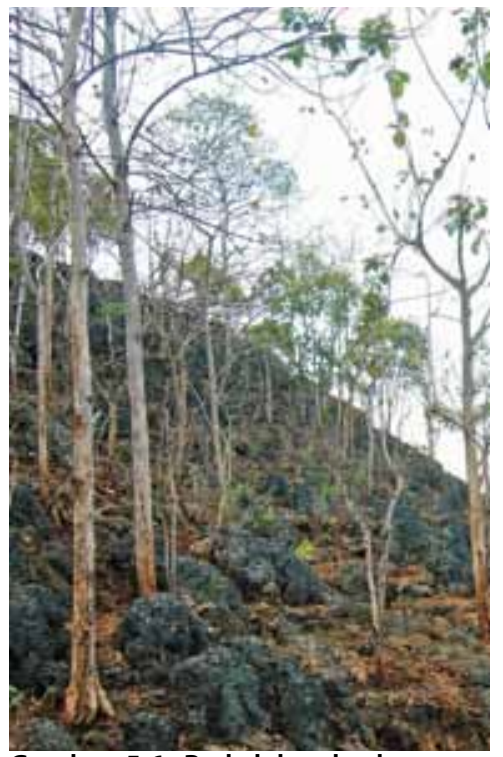

Gambar 5.6. Pada lahan berbatu, pengaturan jarak tanam sulit dilakukan 
- Penjarangan berikutnya bisa dilihat pada Bagian 6 tentang penjarangan.

\section{Berapa sebaiknya ukuran lubang tanam?}

- Ukuran lubang tanam sebaiknya $30 \times 30 \times 30 \mathrm{~cm}$.

- Untuk daerah yang berbatu, lubang tanam dapat dibuat dengan lebar 10-20 cm,dengan menggunakan linggis.

- Di setiap lubang tanam ditancapkan ajir terbuat dari bilahan bambu atau kayu yang berfungsi untuk menandai lokasi lubang tanam.

\section{Teknik apa saja yang digunakan dalam penanaman jati?}

- Hutan jati rakyat dapat berasal dari permudaan alami, yaitu petani mengandalkan anakan yang tumbuh alami di kebun untuk dipelihara menjadi tegakan dewasa.

- Selain itu, hutan jati juga dapat dibangun melalui permudaan buatan, yaitu tanaman jati dibesarkan dari benih atau bibit yang sengaja ditanam pada tempat atau dengan jarak tanam tertentu.

- Dalam permudaan buatan, ada beberapa cara penanaman jati yaitu: ditanam langsung dengan menabur benih di lahan yang disebut dengan sistem cemplongan, atau dengan cara menanam bibit yang berasal dari cabutan atau bibit dari persemaian.

\section{Bagaimana cara penanaman dengan sistem cemplongan?}

- Lahan yang direncanakan ditanami jati, dibuat lubang-lubang (cemplongan) dengan menggunakan kayu runcing/tugal atau linggis.

- Benih jati dimasukkan ke dalam lubang cemplongan sebanyak 2-3 biji. Dengan perkiraan dari masing-masing cemplongan akan tumbuh minimal satu bibit. 
- Jika di dalam satu cemplongan tumbuh lebih dari satu bibit, maka dilakukan seleksi, Seleksi dilakukan ketika bibit berumur 1 tahun (telah melewati satu musim kemarau). Dipilih satu bibit yang pertumbuhannya paling bagus, kemudian dipelihara.

- Jika semua bibit di dalam satu cemplongan pertumbuhannya bagus, maka pilih salah satu bibit yang akan dibiarkan tumbuh, bibit lainnya dicabut untuk ditanam di cemplongan lain yang bijinya tidak tumbuh.

\section{Bagaimana cara penanaman dengan menggunakan bibit?}

- Jika dibawa dari persemaian yang letaknya jauh dari lokasi penanaman, biasanya bibit akan layu akibat kekurangan air selama perjalanan.

- Bibit tersebut sebaiknya jangan langsung ditanam.

- Bibit dipelihara dekat lokasi penanaman selama 1 minggu, agar beradaptasi dengan lingkungan penanaman.

- Bibit siap ditanam pada musim hujan atau ketika curah hujan sudah mencukupi.

- Sebelum penanaman, setiap lubang tanam diberi pupuk dasar terlebih dahulu dengan menggunakan $1 \mathrm{~kg}$ kompos (berasal dari daun-daunan) atau pupuk kandang (berasal dari kotoran ternak).

- Pastikan bahwa kotoran ternak yang dipakai sudah benar-benar matang menjadi pupuk agar tidak berbahaya bagi bibit.

- Penanaman dilakukan 2-4 minggu setelah pemberian pupuk dasar.

- Bibit dikeluarkan dari kantung semai secara hati-hati agar media tanam tetap utuh.

- Kemudian bibit dimasukkan pada lubang tanam, dan ditimbun dengan tanah yang sebelumnya adalah tanah lapisan atas/humus. Selanjutnya masukkan tanah yang berasal dari lapisan bawah.

- Tanah dipadatkan dengan cara bibit dipegang pada bagian batangnya dan tanah di sekitar bibit diinjak perlahan.

- Tempatkan kantung semai pada ujung ajir, sebagai tanda bahwa bibit telah ditanam dan kantung semai tidak ikut tertanam. 
Tanah lapisan atas / humus
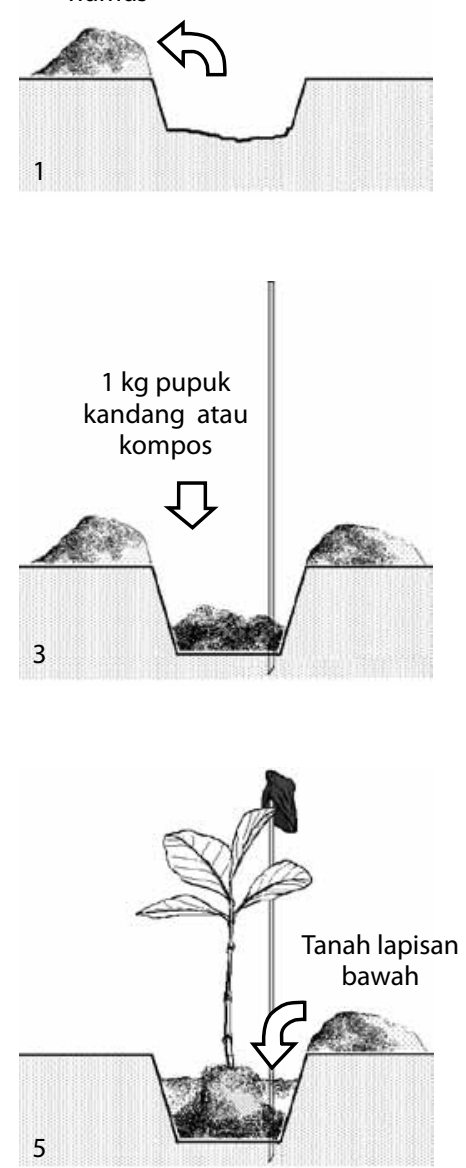
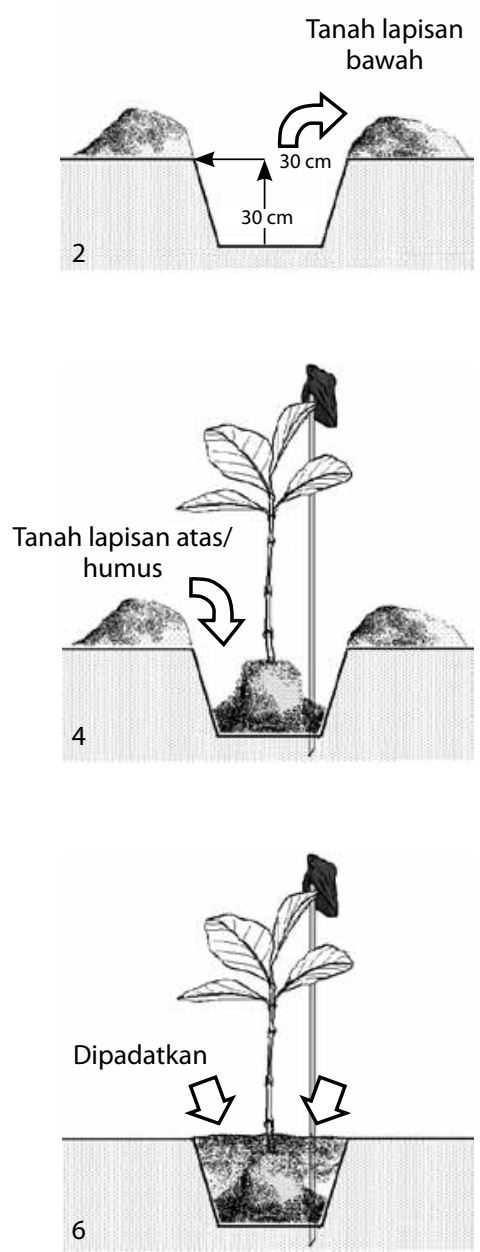

Gambar 5.7. Teknik penanaman bibit 


\section{6 \\ Pemeliharaan Tegakan}

\section{Dalam pemeliharaan tegakan jati, kegiatan-kegiatan apa saja yang sebaiknya dilakukan?}

Agar tegakan jati yang kita miliki dapat tumbuh dengan baik, cepat, dan menghasilkan kayu yang berkualitas, maka harus dilakukan kegiatan pemeliharaan yang meliputi: pembersihan gulma, pemupukan, penyulaman, pemangkasan, penjarangan, pemeliharaan terubusan, dan pencegahan hama penyakit.

\subsection{Pembersihan gulma}

\section{Perlukah tanaman bawah, semak atau rumput dibersihkan dari sekitar pohon jati?}

- Ya, perlu. Pada tanaman jati muda, gulma (tanaman pengganggu) seperti tumbuhan merambat, semak, atau rumput di sekitar tanaman jati perlu dibersihkan secara rutin, karena gulma merupakan saingan tanaman dalam memperoleh cahaya, air, dan unsur hara dalam tanah, dan tumbuhan yang merambat juga mengganggu pertumbuhan jati, bahkan bisa mematikan.

- Pada tanaman jati dewasa atau setelah tajuk bersinggungan, pembersihan gulma tidak sesering pada tanaman muda. Gulma akan mati dengan sendirinya.

- Pembersihan gulma akan lebih berhasil (lebih efektif) jika tanaman jati ditumpangsarikan dengan tanaman pertanian. Pengolahan lahan pada tanaman pertanian sekaligus menjadi kegiatan pembersihan gulma. 


\subsection{Pemupukan}

\section{Bagaimana pemupukannya?}

- Pemupukan dilakukan pada umur 1,2 dan 3 tahun dengan pupuk NPK.

- Dosis pupuk pada tahun pertama $50 \mathrm{gr}$, tahun kedua $100 \mathrm{gr}$ dan tahun ketiga 150 gr per pohon.

- Dapat pula digunakan pupuk kandang/kompos dengan takaran $10 \mathrm{~kg}$ per lubang tanam.

- Pada lahan yang asam ( $\mathrm{pH}$ rendah) dan kurang kapur (Ca), areal di sekitar tanaman perlu diberi kapur tanaman (kapur dolomit) agar pH-nya naik.

- Pemberian dolomit disarankan hanya pada daerah yang memiliki $\mathrm{pH}$ tanah asam. Dolomit bisa diberikan bersama-sama dengan pemberian pupuk dasar sebelum penanaman.

- Dosis yang disarankan untuk pemberian kapur dolomit adalah sekitar 150 sampai 250 gr tiap lubang tanam.

- Sebaiknya pemupukan pada tanaman hutan merupakan satu kesatuan kegiatan dengan pemupukan tanaman pertanian dalam pola tumpang sari.

- Teknik pemberian pupuk dapat dengan cara membuat lubang dengan gejik (pasak kayu) di sebelah kanan-kiri tanaman.

- Dapat pula dengan membuat lubang sedalam $10-15 \mathrm{~cm}$, melingkari tanaman pokok dengan jarak 0,5-1,5 m dari batang jati (melingkar selebar tajuk).

\subsection{Penyulaman}

\section{Mengapa perlu penyulaman?}

- Penyulaman adalah kegiatan mengganti tanaman yang mati dengan bibit baru.

- Penyulaman diperlukan untuk mempertahankan jumlah tanaman atau kerapatan pohon jati dalam luasan tertentu. 
- Penyulaman juga berguna untuk mengganti tanaman yang patah, tidak sehat, atau pertumbuhannya buruk.

- Penyulaman hendaknya dilakukan pada musim hujan.

\subsection{Pemangkasan}

\section{Mengapa pemangkasan diperlukan?}

- Pemangkasan (pruning) merupakan kegiatan pemangkasan cabang pohon. Kegiatan ini bertujuan untuk meningkatkan tinggi bebas cabang dan mengurangi mata kayu dari batang utama.

- Dengan menghilangkan cabang atau ranting yang tidak diperlukan maka nutrisi pohon (sari makanan) akan lebih terpusat untuk pertumbuhan pohon (batang dan tajuk utama).

- Kayu hasil pemangkasan dapat dimanfaatkan sebagai kayu bakar dan tambahan pendapatan petani.

- Dapat mengurangi risiko kebakaran hutan. Tajuk yang bersinggungan dari lantai hutan hingga tajuk pohon teratas akan memudahkan api menjalar menjadi besar.

\section{Bagaimana cara pemangkasan?}

- Pemangkasan dilakukan mulai tahun ke-3.

- Setengah bagian bawah (50\%) dari tinggi total pohon dibersihkan dari cabang dan ranting. Pemangkasan cabang yang berlebihan (lebih dari 50\%) dapat menghambat pertumbuhan pohon jati.

- Pemangkasan dilakukan ketika memasuki awal musim hujan, yaitu sekitar bulan Agustus.

- Pemangkasan sebaiknya dilakukan ketika

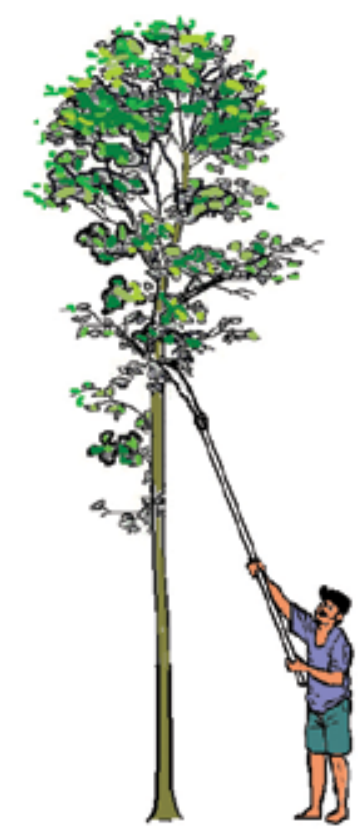

Gambar 6.1 Pemangkasan dengan menggunakan gunting pangkas atau gergaji yang disambung galah cabang atau ranting masih berumur muda (berukuran kecil). 
- Pemotongan cabang sebaiknya sedekat mungkin dengan batang utama, namun tidak sampai memotong leher cabang. Leher cabang adalah bagian yang membesar pada pangkal cabang.

- Sisa cabang yang terlalu panjang pada batang akan menyebabkan cacat mata kayu lepas, atau menjadi sarang bagi hama dan penyakit. Pemotongan cabang yang terlalu dalam akan mengakibatkan luka yang besar sehingga lambat tertutup dan juga berisiko terserang penyakit.

- Pemangkasan dilakukan dengan menggunakan gergaji/gunting wiwil. Untuk ranting kecil/muda pewiwilan dapat menggunakan sabit atau golok yang tajam.

- Agar tidak menjadi tempat masuknya hama dan penyakit, bekas pangkasan dapat ditutup dengan cat atau ter.
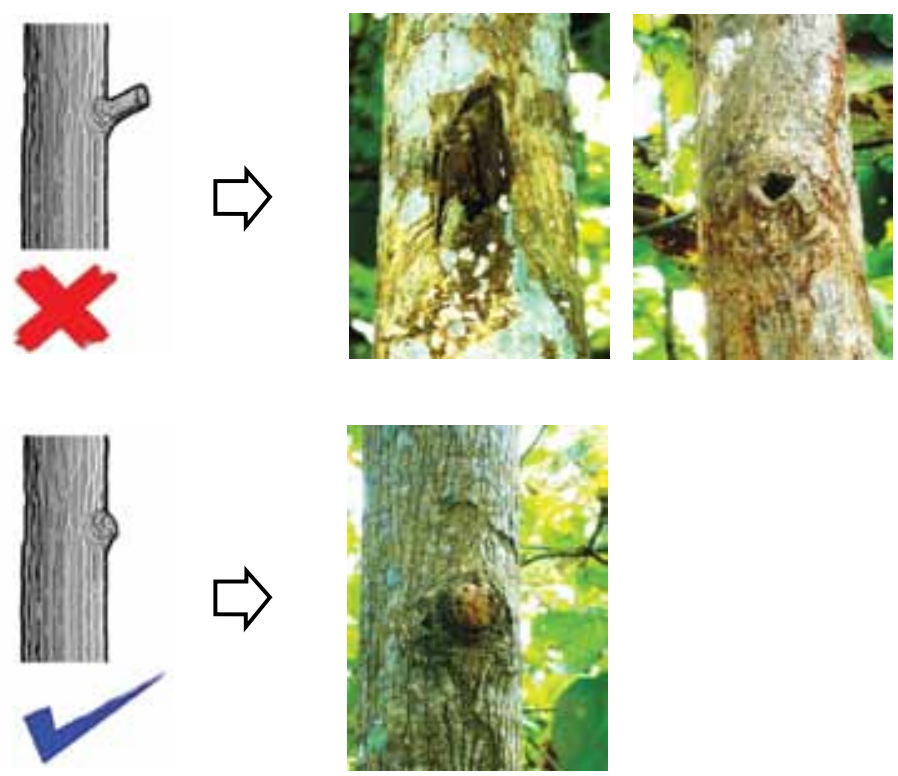

Gambar 6.2. Pengaruh sisa pemangkasan cabang terhadap kualitas batang 

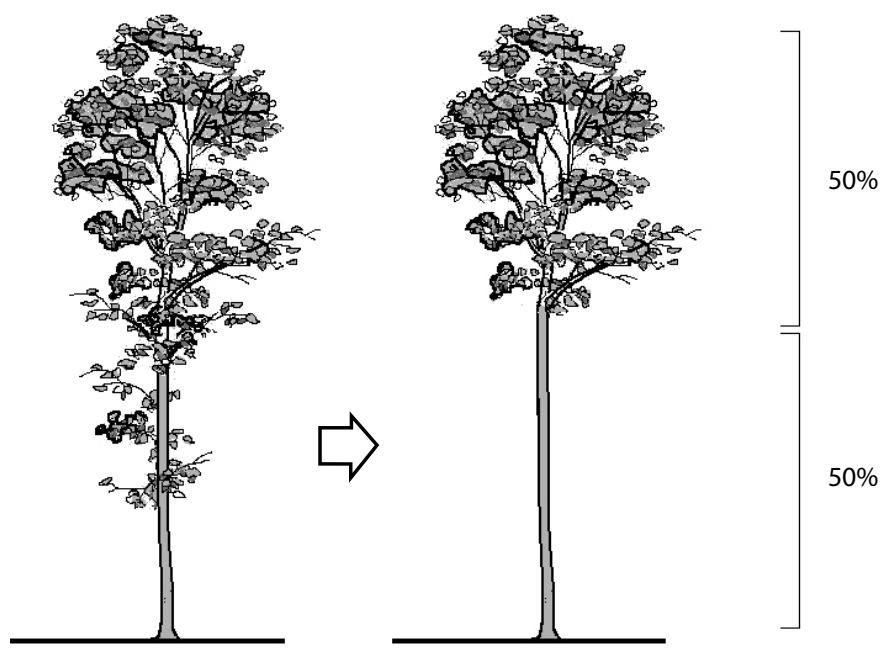

Gambar 6.3. Tinggi cabang yang sebaiknya dipangkas dalam kegiatan pemangkasan

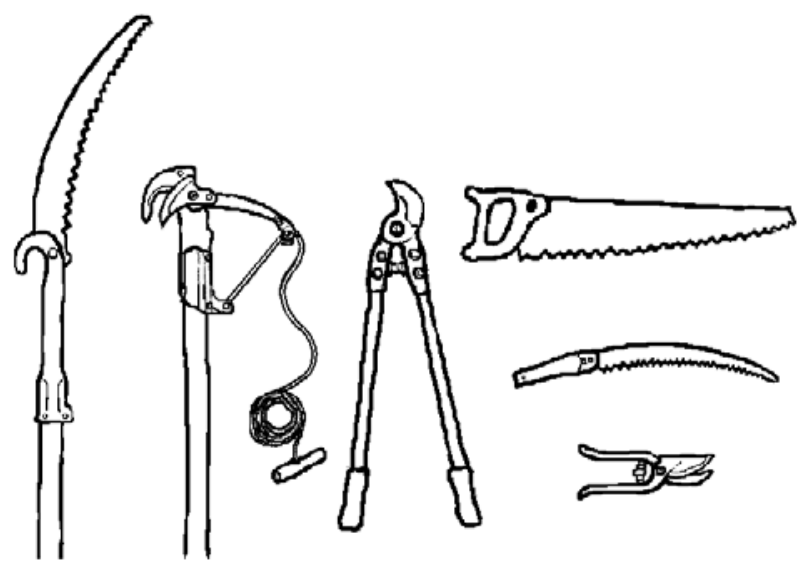

Gambar 6.4. Beberapa macam alat yang dapat digunakan untuk pemangkasan cabang 


\subsection{Penjarangan}

\section{Mengapa pohon harus dijarangkan?}

- Pohon yang terlalu rapat mengakibatkan persaingan antar pohon untuk mendapatkan cahaya, air, dan nutrisi menjadi tinggi dan berakibat tanaman tumbuh lambat, dan bentuk batangnya tidak serasi (tinggi kurus).

- Tanaman yang tertekan dan tidak sehat sebaiknya dibuang untuk memberi kesempatan kepada pohon yang memiliki kualitas baik (tumbuhnya cepat, sehat, dan batangnya bagus) dapat tumbuh maksimal.

- Kegiatan ini bertujuan untuk: (1) mencegah pohon yang sakit agar tidak menularkan penyakitnya ke pohon yang lain, dan (2) penyebaran (distribusi) tanaman menjadi lebih merata.

- Hasil penjarangan dapat digunakan untuk menambah pendapatan. Hasil penjarangan yang berdiameter di atas $10 \mathrm{~cm}$ dapat digunakan untuk kayu pertukangan dan yang berukuran lebih kecil untuk kayu bakar.

\section{Bagaimana cara menjarangkan pohon?}

- Pada hutan jati monokultur seumur, penjarangan dilakukan setiap 3-5 tahun sampai pohon berumur 15 tahun. Penjarangan harus dilakukan lebih sering jika pohon yang ditebang di setiap kegiatan penjarangan jumlahnya sedikit.

- Setelah berumur lebih dari 15 tahun, penjarangan dilakukan setiap 5-10 tahun.

- Pohon yang dijarangkan (ditebang) adalah pohon yang memiliki ciri: terserang penyakit, bentuk batangnya cacat atau tumbuh abnormal, pertumbuhannya lambat atau tertekan, dan bernilai rendah.

- Jika ditemukan jati dengan bentuk batang tidak bagus pada lahan yang kosong, maka pohon tersebut tidak perlu dijarangi agar pohon jati tersebar merata. Pohon tersebut dapat juga ditebang kemudian terubusannya dipelihara. Dengan cara ini menurut pengalaman 


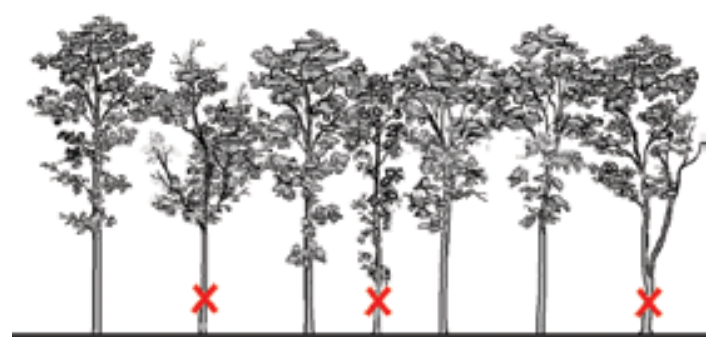

Gambar 6.5. Pohon yang ditebang dan dipertahankan dalam kegiatan penjarangan yang ditanam dengan jarak teratur

petani di Gunungkidul dapat dihasilkan batang baru yang lebih lurus.

- Jumlah pohon yang ditinggalkan setelah penjarangan dapat didasarkan pada ukuran tinggi pohon yang dipengaruhi oleh umur dan kesuburan tanah (bonita).

- Berdasarkan tabel penjarangan Perum Perhutani, ketika rata-rata tinggi pohon 13,5-15,5 m, pohon yang ditinggalkan berjumlah antara 1.000-1.100 pohon/ha. Pada lahan yang subur, hal ini bisa dicapai pada umur 7 tahun, sedangkan pada tanah dengan bonita rendah baru bisa dicapai setelah jati berumur 17 tahun (Lihat Tabel 6.1).

Tabel 6.1. Pohon tertinggal pada penjarangan berdasarkan kesuburan/ tinggi pohon

\begin{tabular}{crcr}
\hline $\begin{array}{c}\text { Tinggi pohon } \\
(\mathrm{m})\end{array}$ & $\begin{array}{c}\text { Jumlah pohon } \\
\text { tertinggal } \\
\text { (pohon/ha) }\end{array}$ & $\begin{array}{c}\text { Umur (tergantung } \\
\text { kesuburan tanah) } \\
(\text { th) }\end{array}$ & $\begin{array}{c}\text { Jarak tanam } \\
(\mathrm{m})\end{array}$ \\
\hline $11,0-13,0$ & $1.300-1.500$ & $5-11$ & $2,5 \mathrm{sd} 3$ \\
$13,5-15,5$ & $1.000-1.100$ & $7-17$ & 3 \\
$15,5-17,0$ & $800-850$ & $10-21$ & 3,5 \\
$17,5-21,0$ & $500-550$ & $15-34$ & $4 \mathrm{sd} \mathrm{4,5}$ \\
\hline
\end{tabular}

Sumber : Modifikasi Tabel Penjarangan Perum Perhutani (Perhutani 2001) 


\section{Bagaimana jika pohon jatinya tidak seumur?}

- Pada hutan monokultur, seumur, dan jarak tanam teratur, penjarangan relatif mudah dilaksanakan. Pohon yang tumbuh lambat atau tertekan akan mudah dibedakan dengan pohon normal jika pohon jatinya seumur.

- Untuk hutan jati rakyat yang tidak seumur dan jarak tanamnya tidak teratur, pelaksanaan penjarangan lebih sulit. Pedoman umum yang dapat dipakai adalah:

a. Pusatkan perhatian pada masing-masing pohon, jika suatu pohon ditebang, bagaimana kelak pengaruhnya terhadap pohon-pohon yang ada di sekitarnya, atau bagaimana pertumbuhannya jika pohon-pohon di sekitarnya yang ditebang.

b. Jika tajuk saling tumpang tindih, hal ini merupakan tanda bahwa tegakan harus dijarangi.

c. Tebanglah pohon-pohon yang berada di bawah tajuk pohon lain (tidak mendapatkan cukup cahaya), berpenyakit, kondisi atau kualitas batangnya buruk.

d. Pohon tidak perlu ditebang/dijarangi jika hanya tajuk bagian bawah yang ternaungi.

e. Anakan atau tanaman muda yang berada di tempat terbuka dibiarkan tetap tumbuh.

f. Untuk menjaga keragaman ukuran/umur pohon, misal agar diperoleh variasi masa panen, sebaiknya tegakan yang tertinggal setelah penjarangan diupayakan masih mewakili berbagai kelas umur/diameter.

- Penjarangan untuk memperbaiki kualitas jati dapat juga dilakukan terhadap pohon berukuran besar (pohon yang telah laku dijual), dikenal dengan penjarangan komersial.

- Pola penjarangan ini cocok untuk hutan jati yang difungsikan sebagai tabungan. Ketika membutuhkan dana, petani tidak selalu menebang pohon yang terbesar. Pohon yang ditebang dipilih, agar pohon-pohon yang tertinggal tumbuh optimal dan tersebar merata. 
- Penjarangan komersial dilakukan pada:

a. pohon besar untuk membuka tajuk agar pohon-pohon yang lebih kecil mendapat cahaya lebih banyak sehingga tumbuh lebih cepat dan sehat,

b. pohon yang jika ditebang akan menyebabkan tajuk pohon seumur di sekitarnya (yang memiliki bentuk lebih bagus) berkembang lebih subur dan tumbuh maksimal, atau

c. pohon-pohon yang terlalu rapat.

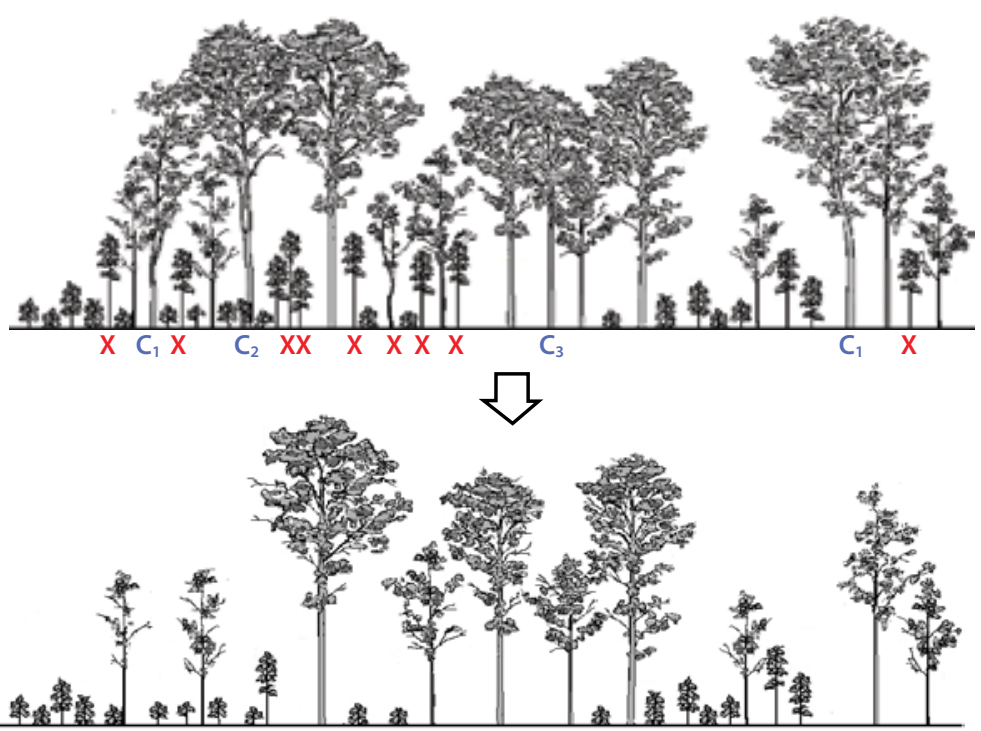

Keterangan:

$\mathrm{X}=$ Penjarangan non komersial

$\mathrm{C}=$ Penjarangan komersial

C1 $=$ Pohon dijarangi untuk membuka tajuk agar tanaman yang potensial dapat tumbuh optimal

$\mathrm{C} 2=$ Pohon yang jika ditebang menyebabkan tajuk pohon di sekitarnya berkembang lebih subur

C3 $=$ Pohon yang terlalu rapat

Gambar 6.6. Contoh penjarangan pada hutan jati tidak seumur 


\subsection{Pemeliharaan terubusan}

\section{Bagaimana memelihara terubusan dari tunggak jati?}

- Tunggak jati bekas tebangan jika dibiarkan akan menghasilkan terubusan yang dapat dipelihara hingga dewasa.

- Terubusan biasanya mampu tumbuh lebih cepat dari pada pohon yang berasal dari benih.
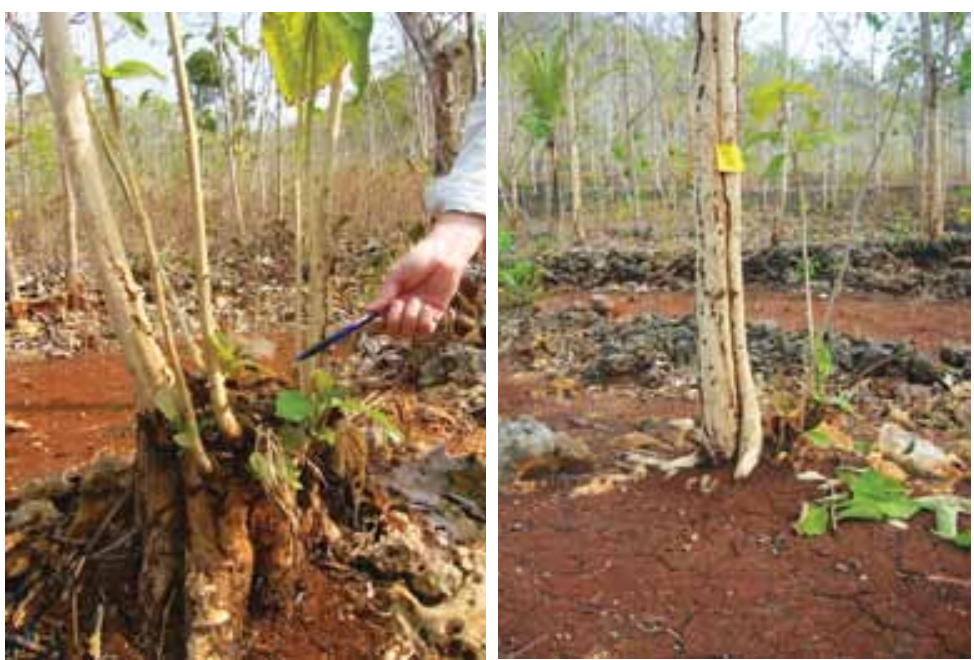

Gambar 6.7. Pengelolaan pohon jati dari terubusan bekas tebangan a) Terubusan saat masih muda, b) Satu batang disisakan untuk tumbuh menjadi pohon besar

- Karena akar pada terubusan seringkali hanya berkembang di satu sisi, maka membangun hutan jati dari terubusan memiliki kelemahan yaitu pohon tidak tahan terhadap terpaan angin dan kayunya sering berlubang (growong).

- Untuk mengurangi kemungkinan pohon roboh dan kayu berlubang, maka penebangan pohon hendaknya dilakukan setinggi permukaan tanah. Dengan cara ini tunggak akan 
tertimbun tanah dan terubusan pada tunggak akan memiliki akar yang tumbuh lebih merata di semua sisi.

- Tunggak yang memiliki terubusan lebih dari satu sebaiknya terubusannya dijarangkan.

- Pilih satu terubusan yang paling potensial yaitu penampilannya paling sehat, besar, lurus, dan paling dekat dengan tanah. Terubusanterubusan lainnya dipotong pada pangkal tunggak.

- Penjarangan dilakukan secara rutin setiap tumbuh terubusan baru, agar pertumbuhan pohon terpusat pada terubusan yang terpilih.

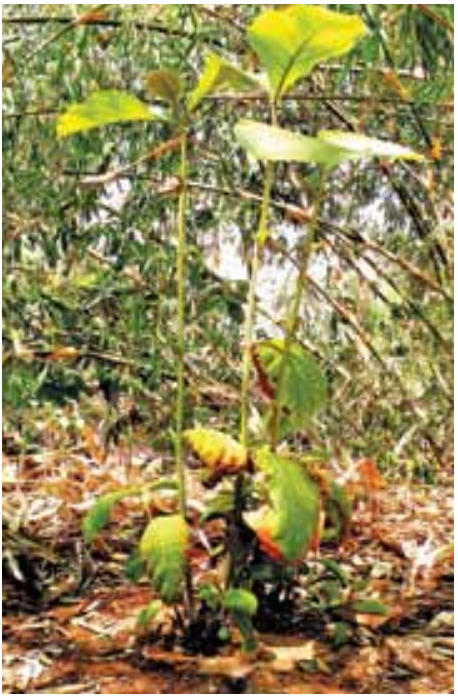

Gambar 6.8. Terubusan pada tunggak yang rata dengan tanah

\subsection{Pengendalian hama dan penyakit}

\section{Hama apa yang sering menyerang tanaman jati?}

Hama yang ditemukan menyerang jati adalah:

1. Neotermes tectonae (inger-inger) yaitu sejenis rayap pohon. Serangan rayap ini menyebabkan pembengkakan (gembol) pada batang atau cabang. Pohon jati dapat terinfeksi inger-inger pada umur 3 tahun. Serangannya baru terlihat setelah umur 7 tahun.
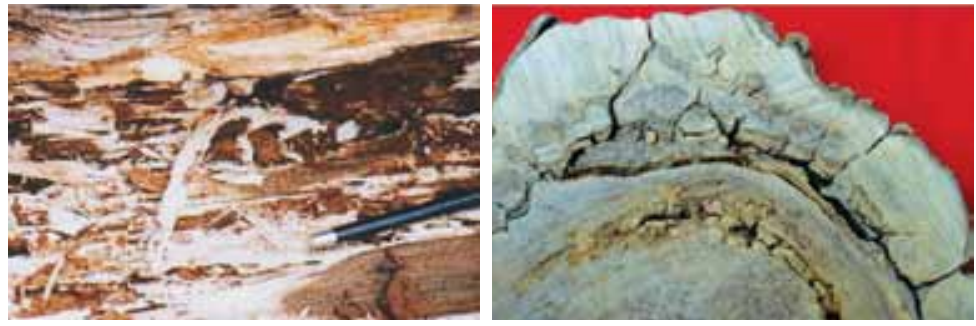

Gambar 6.9. Kerusakan kayu yang diakibatkan oleh hama inger-inger 


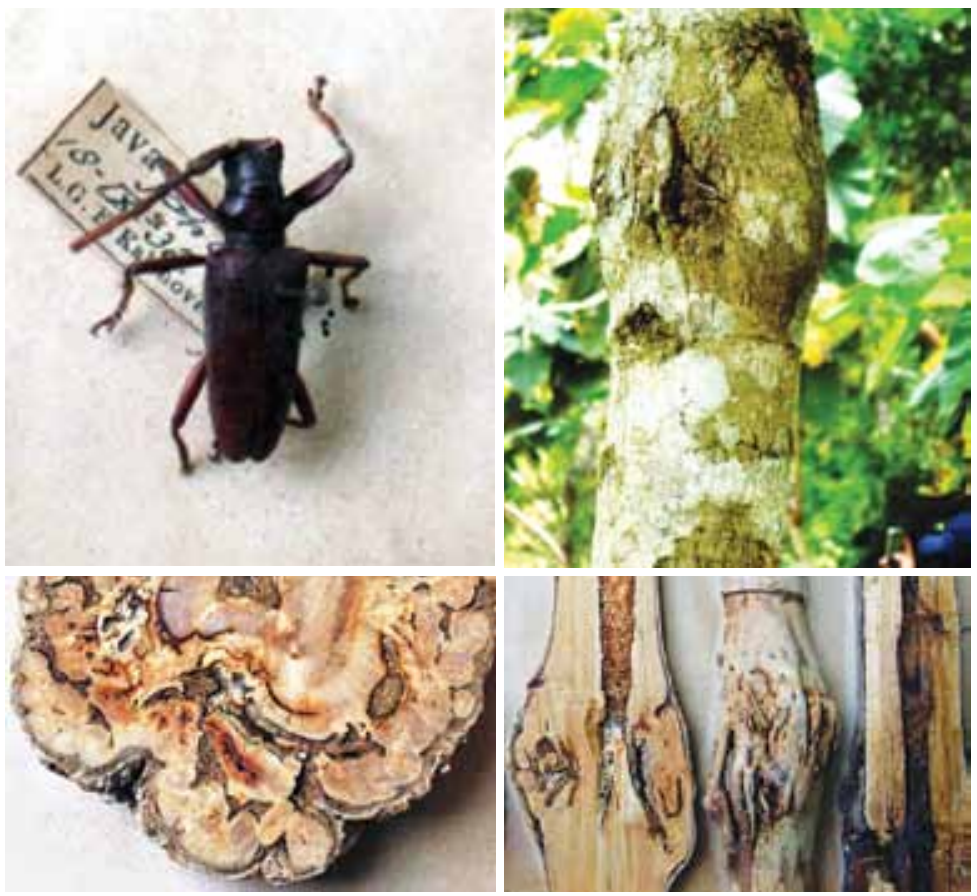

Gambar 6.10. Ulan-ulan dan kerusakan yang diakibatkan oleh serangannya

2. Penggerek batang jenis Monohammus rusticator (ulan-ulan). Hama ini dapat menyebabkan lubang, pembengkakan, dan patah pada batang.

3. Xyleborus destruens (penggerek bubuk kayu basah). Batang digerek oleh hama ini dengan arah melintang. Apabila kulit kayu dikelupas tampak lubang-lubang pada kayu dengan pinggir lubang terdapat noda hitam. Tanaman jati yang diserang umumnya berumur 5 tahun ke atas.

4. Pyrausta machaeralis, Eutectona machaerallis dan Hyblaea puera atau ulat jati yang umumnya menyerang daun.

5. Holotrichia helleri dan Lepidiota stigma yang dikenal dengan nama uret. Uret umumnya menyerang akar bibit jati dan tanaman muda (umur 1-2 tahun). Tanaman menjadi layu dan akhirnya mati kering karena akarnya habis. 


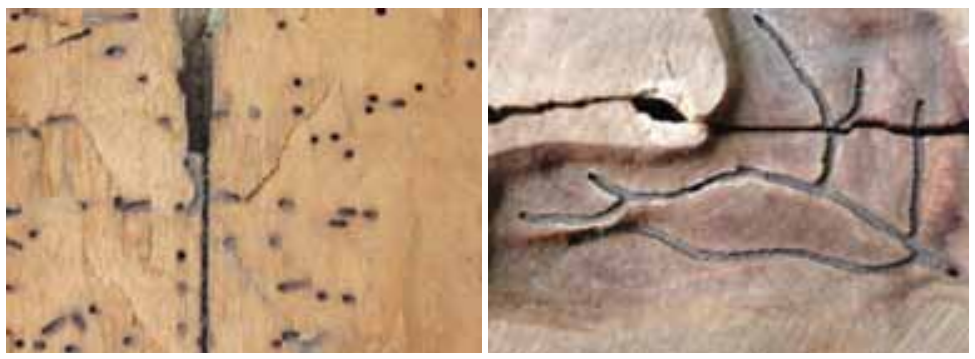

Gambar 6.11. Serangan penggerek bubuk kayu basah menyebabkan kayu berlubang ke arah dalam (melintang)

\section{Bagaimana mengendalikan serangan inger-inger?}

- Meluasnya serangan inger-inger dapat dicegah dengan kegiatan penjarangan yang teratur.

- Penebangan/penjarangan terhadap pohon yang terserang ingeringer harus dilakukan sebelum awal musim hujan di saat laron inger-inger belum keluar.

- Bagian-bagian tanaman yang diserang dipotong dan dibakar.

- Pengendalian secara kimiawi untuk membunuh inger-inger dapat menggunakan insektisida fumigan phostoxin $1 / 4$ tablet atau menggunakan insektisida berbahan aktif fenpropatrin (Meothrin $50 \mathrm{EC})$.

\section{Bagaimana mengatasi serangan penggerek batang?}

Pengendaliannya dengan insektisida fumigan phostoxin, disuntikkan pada batang yang terserang melalui lubang-lubang gerek.

\section{Bagaimana pengendalian serangan bubuk kayu basah?}

- Untuk menghindari serangan bubuk kayu basah, sebaiknya jangan menanam jati di daerah-daerah di mana tidak ada perbedaan yang nyata antara musim hujan dan musim kemarau. 
- Bila di suatu daerah telah terjadi serangan bubuk kayu secara hebat, maka di daerah tersebut jangan ditanami jati lagi.

- Lakukan pembersihan gulma di sekitar tanaman, untuk mengurangi kelembapan.

- Insektisida yang bisa dipakai untuk membasmi penggerek bubuk kayu basah antara lain Brash 25 EC, Lentrek 400 EC, Dragnet 380 EC, Enborer $100 \mathrm{EC}$ dan Cislin 2,5 EC.

\section{Bagaimana mengatasi serangan ulat jati?}

- Menurut pengalaman petani di Gunungkidul, serangan ulat (Hyblaea puera) tidak berbahaya bagi pohon jati. Serangan hanya berlangsung sekitar 1 minggu. Ulat jati ketika akan menjadi kepompong secara alami akan turun dari pohon, biasanya petani pada pagi hari mengumpulkan ulat-ulat ini untuk dimakan atau diperdagangkan.

- Cara pengendalian serangan ulat jati adalah dengan tidak merusak tumbuh-tumbuhan bawah yang menjadi tempat hidup musuh alami ulat jati, misalnya burung.

- Secara kimia pengendalian ulat jati dapat dilakukan dengan menggunakan insektisida berbahan aktif deltametrin (Decis 2,5 EC), berbahan aktif permetrin (Ambush $2 \mathrm{EC}$ ) dan berbahan aktif lamda sihalotrien (Matador $25 \mathrm{EC}$ ).

\section{Bagaimana pengendalian serangan uret?}

Menurut Anggraeni dan Asmaliah (2007) ada beberapa cara penanggulangannya yaitu:

- Larva dikumpulkan pada saat pengolahan tanah kemudian dimusnahkan, atau kumbang-kumbang ditangkap pada malam hari dengan bantuan lampu.

- Campurkan insektisida kimia dengan tanah pada lubang tanam sebelum atau pada saat penanaman.

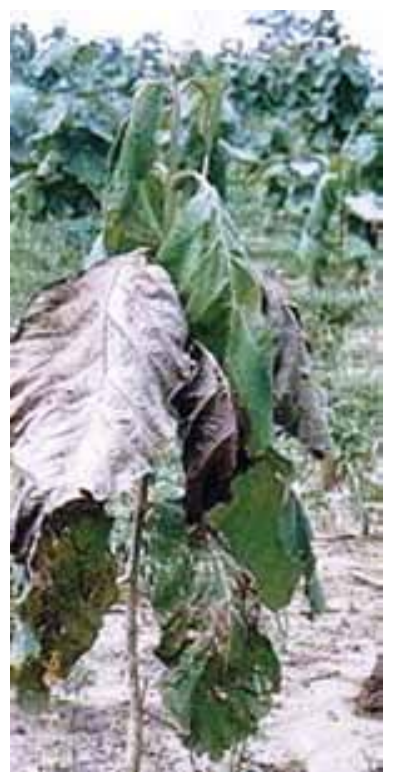

Gambar 6.12. Bibit jati yang terserang penyakit layu 
- Contoh insektisida yang dapat digunakan adalah yang berbahan aktif karbosulfan (Marshal 5G), berbahan aktif karbofuran (Curaterr 3G, Furadan 3G, Petrofur 3G dan Indofuran), berbahan aktif etoprofos (Rhocap 10G), dan berbahan aktif diazinon (Diazinon 10G).

- Secara tradisional, petani di Gunungkidul membasmi uret antara lain dengan menggunakan gadung yang diparut, kulit buah jambe, atau biji mahoni yang dihaluskan kemudian dicampur dan disiramkan di sekitar lubang atau di seluruh lahan.

\section{Apa saja penyakit yang menyerang jati?}

- Penyakit layu yang disebabkan oleh bakteri Pseudomonas tectonae. Penyakit ini umumnya menyerang bibit jati yang masih di persemaian atau jati muda di lapangan. Gejala awalnya adalah adanya bercak-bercak berwarna coklat muda atau tua kemudian timbul kelayuan pada seluruh daun, dan daun menjadi pucat kekuningan. Daun dapat layu secara perlahan atau serentak kemudian rontok dalam waktu singkat.

- Penyakit mati pucuk yang disebabkan oleh jamur Phoma sp. Penyakit ini biasanya terjadi pada jati muda. Serangan terjadi di saat daun jati bersemi dan menyebabkan beberapa pucuk daun mati. Pertumbuhan tanaman menjadi tidak lurus dan terhambat.

- Penyakit jamur upas (Corticium salmonicolor). Penyakit jamur upas sering timbul dan mudah menular secara cepat pada musim hujan. Gejala penyakit yang tampak dari luar, daun jati layu tergantung lemas dengan warna hitam gelap seperti tersiram air panas. Terdapat lapisan badan buah yang menebal pada kulit batang, timbulnya benjolanbenjolan pada permukaan batang, bagian kulit dan kayu pecah-pecah dan luka.

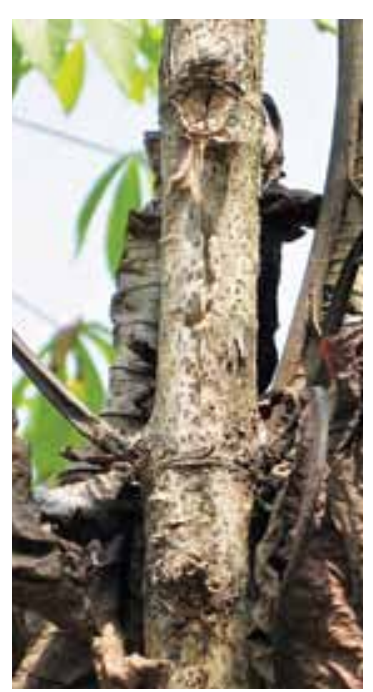

Gambar 6.13. Batang dan daun jati yang terkena jamur upas 
- Penyakit kanker batang yang disebabkan oleh Nectria haematococca. Gejala diawali dengan daun layu dan berwarna hitam gelap, kemudian muncul benjolan lapisan gabus di permukaan batang. Selanjutnya kulit kayu pecah-pecah, terjadi luka, dan lubang-lubang memanjang pada batang.

\section{Bagaimana mengendalikan penyakit layu?}

- Pengobatan dapat dilakukan apabila serangan masih ringan yaitu dengan bakterisida yang berbahan aktif streptomisin sulfat (Agrept 20 WP), berbahan aktif dazomet (Basamid G), dan bahan aktif asam oksolinik (Starner 20 WP).

- Agar lebih aman, jika tampak gejala penyakit pada tanaman atau bibit, segera musnahkan bibit tersebut dengan cara dibakar.

- Tumpangsari pada jati muda hendaknya jangan menggunakan jenis tanaman dari suku Solanaceae (misal: terong, kentang, tomat, dan cabai) karena sayuran ini dapat menjadi sarana penularan (inang) penyakit layu bakteri.

\section{Bagaimana mengendalikan penyakit mati pucuk?}

Cara pengendaliannya menurut Rahayu (1999) adalah:

- Pada musim hujan, pucuk-pucuk yang terserang segera dipotong untuk menghindari penularan.

- Kelembapan lingkungan dikurangi dengan memangkas cabang pohon-pohon.

- Dilakukan pemupukan untuk memacu pertumbuhan tanaman dan pembentukan tunas baru.

\section{Bagaimana mengendalikan penyakit jamur upas?}

Cara pengendaliannya adalah:

- Matikan tanaman lantana yang terdapat di sekitar tanaman jati karena merupakan sumber infeksi.

- Jarak tanam dijaga melalui penjarangan yang rutin sesuai dengan ukuran atau umur pohonnya. 
- Lakukan pengontrolan dan pemangkasan yang teratur.

- Pengendalian dapat dilakukan dengan menggunakan fungisida yang berbahan aktif karbendazim (Derosal 60 WP) dengan cara pengolesan atau penyemprotan.

\section{Bagaimana mengendalikan penyakit kanker batang?}

Cara pencegahan dan pengendalian serangan kanker batang adalah:

- Lahan di sekitar jati dibersihkan dari tanaman inang seperti Lantana sp. (kembang telek, tembelekan, atau tahi ayam).

- Jarak tanam diatur agar tanaman terkena cahaya matahari dan sirkulasi udaranya baik.

- Lakukan pemangkasan secara teratur.

- Bila sudah terjadi serangan maka perlu dilakukan pemberantasan penyakit dengan cara: batang yang luka dikerok kemudian diolesi dengan kooltir, TB 192, fungisida Fylomac 0,5\%, atau Antimuci $0,5 \%$ setiap 3 minggu sekali. 



\section{7}

\section{Pemanenan}

\section{Kapan jati sebaiknya ditebang?}

Agar dapat memberikan penghasilan yang maksimal sebaiknya pohon jati ditebang jika:

- telah cukup dewasa untuk menghasilkan kayu berkualitas baik, minimal pohon telah berumur sekitar 15-20 tahun;

- harga kayu sedang tinggi.

\section{Bagaimana mengukur volume kayunya?}

- Volume pohon berdiri dapat dihitung dengan menggunakan tabel volume jati, yang disesuaikan dengan kualitas lahan tempat jati ditanam. Contoh tabel volume jati dapat dilihat di Lampiran 2.

- Diameter batang (Dbh) diukur dari batang setinggi dada $(130 \mathrm{~cm})$.

- Perhitungan volume batang kayu /log dapat dilakukan dengan menghitung rata-rata luas bidang dasar pangkal dan ujung dan dikalikan dengan panjang batang. Rumusnya adalah:

Volume batang $=\left(1 / 4 \times 3,14 \times\right.$ diameter pangkal batang $\left.{ }^{2}\right)+$ $\left(1 / 4 \times 3,14 \times\right.$ diameter ujung batang $\left.{ }^{2}\right) \times 1 / 2$ $x$ panjang batang.

\section{Bagaimana cara menebangnya?}

- Tidak disarankan untuk melakukan penebangan pohon pada satu sisi. Sebaiknya penebangan dilakukan dengan penebangan dua sisi agar batang jati tidak pecah dan rebahnya pohon lebih terarah. 


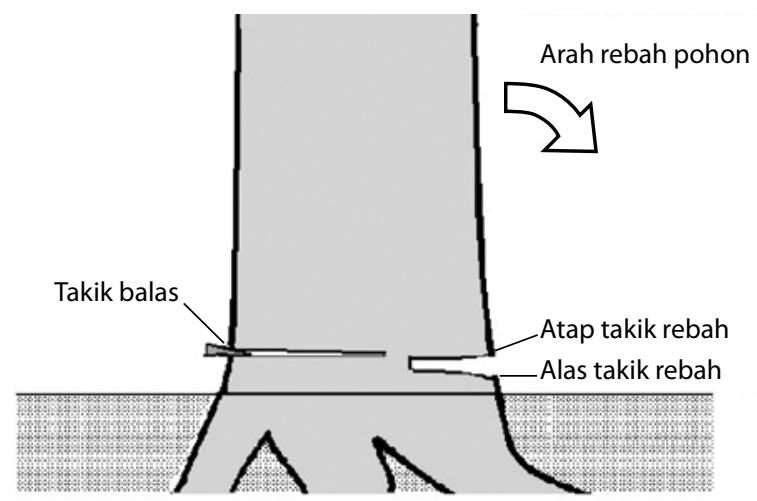

Gambar 7.1. Teknik penebangan pohon dua sisi

- Pertama, tentukan arah rebah pohon untuk meminimalkan kerusakan pohon lain.

- Sebelum pohon ditebang, cabang dan ranting dikurangi.

- Satu sisi batang digergaji sejajar dengan arah rebah pohon, disebut takik rebah. Jarak antara alas dan atap takik rebah maksimal $5 \mathrm{~cm}$.

- Kemudian pada sisi lainnya juga digergaji setinggi atap takik rebah, sebagai takik balas. (Lihat Gambar 7.1).

\section{Bagaimana pola penebangan hutan jati?}

Ada beberapa pola penebangan yang berkaitan dengan sistem silvikultur yang dapat diterapkan di hutan jati rakyat, yaitu:

- Pola tebang habis. Semua pohon dalam satu area tertentu ditebang semua. Biasanya dilakukan pada hutan jati seumur (Gambar 7.2).

- Pola tebang pilih. Pohon yang ditebang dipilih sesuai dengan kebutuhan. Cara ini umumnya dilakukan pada tegakan jati tidak seumur, atau hutan campuran. Pola ini juga dapat dipraktekkan untuk kegiatan tebang butuh atau penjarangan komersial (lihat penjarangan hutan tidak seumur pada halaman 50-51 dan Gambar 7.3). 


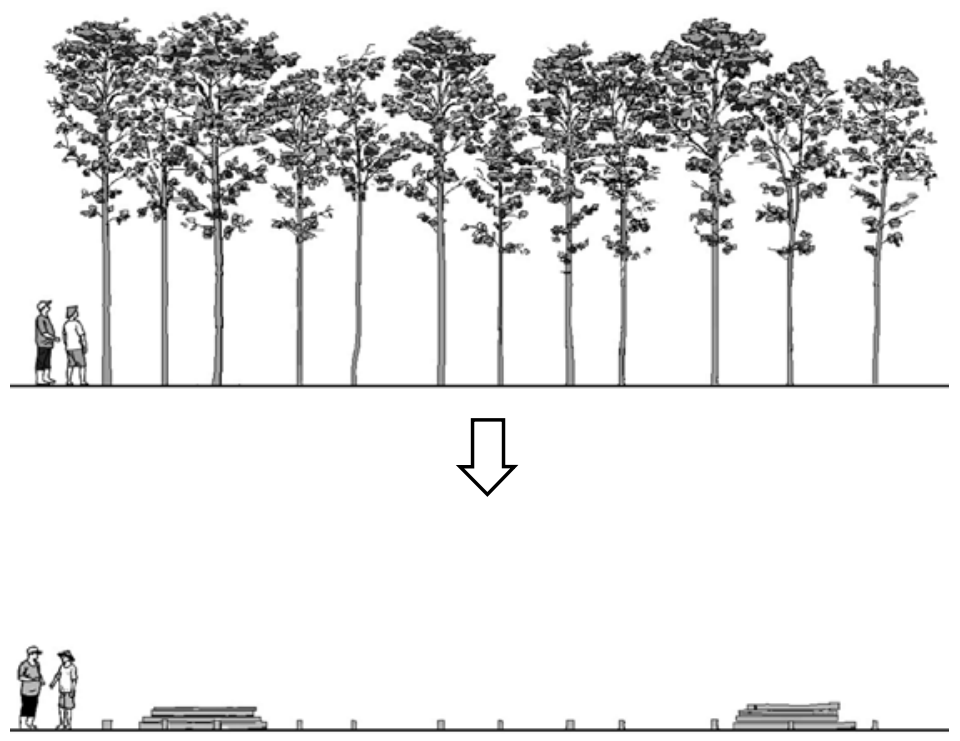

Gambar 7.2. Pemanenan dengan pola tebang habis
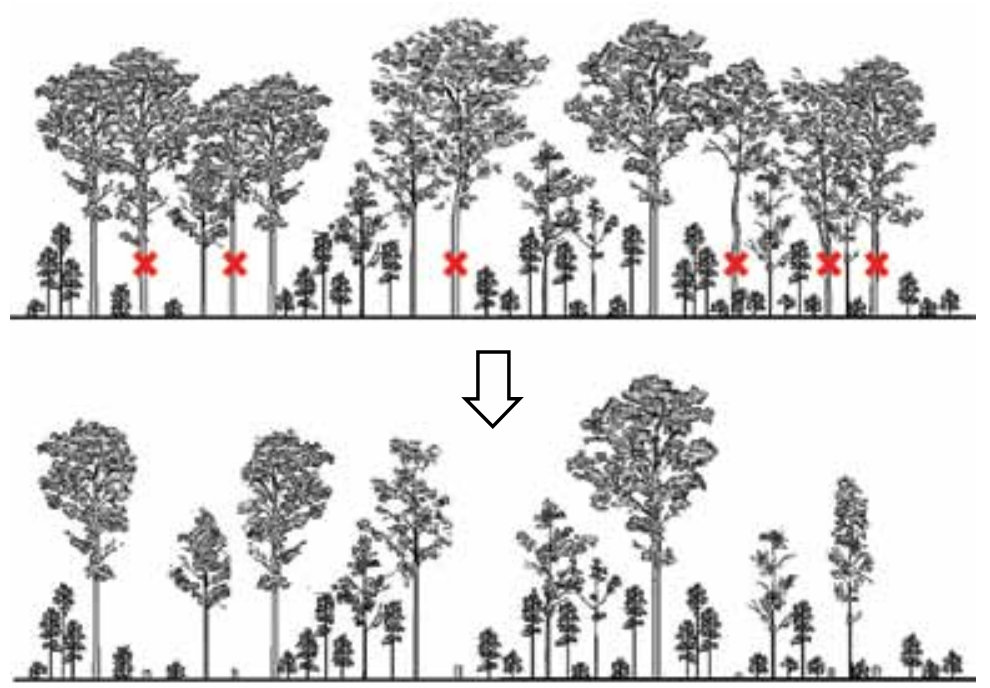

Gambar 7.3. Pemanenan dengan pola tebang pilih 



\section{Bahan Bacaan}

\section{Pendahuluan}

Simatupang, M.H. 2000 Some notes on the origin and establishment of teak forest (Tectona grandis L.f.) in Java, Indonesia. Dalam: Third Regional Seminar on Teak. Potential and Opportunities in Marketing and Trade of Plantation Teak Challenge for the New Millenium. Yogyakarta, Indonesia.

Soerianegara, I. dan Lemmens, R.H.M.J. 1994 Timber trees: major commercial timbers. Plants Resources of South-East Asia 5(1). Prosea. Bogor, Indonesia.

Anggraeni, I. dan Asmaliyah 2008 Hama dan penyakit tanaman jati (Tectona grandis L.f.). Dalam: Hendromono, B. Leksono, A. dan Setyabudi (eds). Prosiding Seminar Potensi dan Tantangan Pembudidayaan Jati di Sumatera, 30 November 2007. Puslitbang Hutan Tanaman. Badan Litbang Kehutanan. Bogor, Indonesia.

\section{Silvikultur Jati}

Daniel, T. W., Helms, J.A., dan Baker, F.S. 1992 Prinsip-prinsip silvikultur. University Press, Gadjah Mada. Diterjemahkan oleh Djoko Marsono, Yogyakarta.

Shepherd, K. R.1986 Plantation silviculture. Martinus Nijhoff Dordrecht, Netherlands.

Smith, D.M. 1962 The practice of silviculture. $7^{\text {th }}$ Ed. John Wiley \& Sons, New York.

\section{Penyiapan Benih}

Mulawarman, Roshetko, J.M., Sasongko, S.M. dan Iriantono, D. 2003 Tree seed management - Seed sources, seed collection and seed handling: a field manual for field workers and farmer. World Agroforestry Centre dan Winrock International. Bogor, Indonesia.

Nurhasybi 2003 Jati (Tectona grandis L.f.) dalam atlas benih tanaman hutan Indonesia. Publikasi Khusus (3)8. Balai Penelitian dan Pengembangan Teknologi Perbenihan. Badan Litbang Kehutanan, Bogor. Indonesia. 


\section{Pembuatan Bibit}

Perhutani 2007 Standar Operasional Prosedur (SOP) pembuatan persemaian Jati Plus Perhutani (JPP). Pusat Penelitian dan Pengembangan Perum Perhutani, Cepu, Indonesia.

Wibowo, A. 1999 Studi variasi genetik tentang kemampuan perakaran setek pucuk jati (Tectona grandis L.f.) dari kebun pangkas di Cepu. Tesis Pasca Sarjana UGM, Yogyakarta. Tidak Dipublikasikan. Hal. $22-23$.

Mahfudz, M. A. Fauzi, Yuliah, Herawan, T., Prastyono, dan Supriyanto, H. 2003 Sekilas tentang jati (Tectona grandis L.f.), Puslitbang Bioteknologi dan Pemuliaan Tanaman Hutan, Yogyakarta. Indonesia.

BPTH Bandung 2000 Buku standar mutu bibit. Berdasar SNI 01-5006.11999. Akasia, ampupu, gmelina, sengon, tusam, meranti dan tengkawang. Ditjen Rehabilitasi Lahan dan Perhutanan Sosial, Departemen Pertanian dan Kehutanan. Bandung, Indonesia.

\section{Penanaman}

Kosasih, A.S., Bogidarmanti, R. dan Rustaman, B. 2006 Silvikultur hutan tanaman campuran. Pusat Penelitian dan Pengembangan Hutan Tanaman. Badan Penelitian dan Pengembangan Kehutanan, Bogor. Indonesia.

Hairiah, K., Widianto, Suprayogo, D., et al. 2006 Root effects on slope stability in Sumberjaya, Lampung, Indonesia. Paper dipresentasikan dalam International Symposium toward Sustainable Livelihood and Ecosystems in Mountanious Regions, Chiang Mai, 7-9 Maret 2006.

Hendromono, Daryono, H. dan Durahim 2005 Pemilihan jenis pohon untuk rehabilitasi lahan kritis. Dalam: Prosiding ekspose penerapan hasil Litbang Hutan dan Konservasi Alam. Palembang 15 Desember 2004. Pusat Litbang Hutan dan Konservasi Alam. Badan Litbang Kehutanan, Departemen Kehutanan. Jakarta, Indonesia.

Soerianegara, I. dan Lemmens, R.H.M.J. 1994 Timber trees: major commercial timbers. Plant resources of South-East Asia 5(1) Bogor.

Mahfudz, M. A. Fauzi, Yuliah, Herawan, T., Prastyono, dan Supriyanto, H. 2003 Sekilas tentang jati (Tectona grandis L.f.), Puslitbang Bioteknologi dan Pemuliaan Tanaman Hutan, Yogyakarta. Indonesia. 
Mindawati, N., Widiarti, A. dan Rustaman, B. 2006. Review hasil penelitian hutan rakyat. Pusat Penelitian dan Pengembangan Hutan Tanaman. Badan Penelitian dan Pengembangan Kehutanan, Bogor. Indonesia.

\section{Pemeliharaan Tegakan}

Anggraeni, I., Intari, S.E. dan Darwiati, W. 2006. Hama penyakit hutan tanaman. Pusat Penelitian dan Pengembangan Hutan Tanaman. Badan Penelitian dan Pengembangan Kehutanan, Bogor. Indonesia.

Anggraeni, I. dan Asmaliyah 2008 Hama dan penyakit tanaman jati (Tectona grandis L.f.). Dalam: Hendromono, B. Leksono, A. dan Setyabudi (eds). Prosiding seminar potensi dan tantangan pembudidayaan jati di Sumatera. Palembang, 30 November 2007. Puslitbang Hutan Tanaman. Badan Litbang Kehutanan, Bogor. Indonesia.

Axelsson, R. 2008 Forest policy, continuous tree cover forest and uneven-aged forest management in Sweden's boreal forest. Licentiate thesis. Report No 7. The Swedish University of Agricultural Sciences, Department of Forest Products. Uppsala.

Christopherson, J. Forest thinning and defensible space. University of Nevada Cooperative Extension. http://www.unce.unr.edu/ publications/files/nr/other/fs9255.pdf [18 Agusut 2010].

Degomez, T. 2006 Guidelines for thinning ponderosa pine for improved forest health and fire prevention. Publication Az1397. 03/2006. The University of Arizona. Tucson, Arizona.

Direktorat Hutan Tanaman Industri 1991 Teknik pembuatan tanaman jati (Tectona grandis L.f.). Direktorat Jenderal Reboisasi dan Rehabilitasi Lahan. Departemen Kehutanan. Jakarta, Indonesia.

Hardi, T., Ismail, B., Mahfudz dan Wiraadinata, P. 2005 Hama inger-inger pada tanaman jati. Dalam: Pengembangan jenis jati unggul untuk peningkatan produktivitas hutan rakyat. Prosiding Pertemuan Forum Komunitas Jati IV. Yogyakarta, 14 Oktober 2005. Pusat Penelitian dan Pengembangan Hutan Tanaman. Badan Litbang Kehutanan Departemen Kehutanan. Bogor, Indonesia.

Haygreen, J.G. dan Bowyer, J.L. 1996 Forest products and wood science: an introduction. Third Edition. lowa University Press. lowa, USA. 
Perhutani 2001 Petunjuk pelaksanaan penjarangan hutan tanaman kayu jati. Cetakan ke-2. Biro Pembinaan Sumberdaya Hutan. PT. Perhutani (Persero) Unit I Jawa Tengah. Semarang, Indonesia.

Perhutani 2001 Petunjuk pelaksanaan pemeliharaan hutan lanjutan. Biro Pembinaan Sumberdaya Hutan. PT. Perhutani (Persero) Unit I Jawa Tengah. Semarang, Indonesia.

Rahayu, S. 1999 Penyakit tanaman hutan di Indonesia: gejala, penyebab dan teknik pengendaliannya. Kanisius. Yogyakarta, Indonesia.

Suharti, M. dan Intari, S.E. 1974 Pedoman pengenalan beberapa hama dan penyakit pada jati (Tectona grandis L.f.). Laporan No. 182. Lembaga Penelitian Hutan, Bogor. Indonesia.

Sumarna, Y. 2004 Budidaya jati. PT Penebar Swadaya. Jakarta.

Tarumingkeng, R. C. 1973 Serangan inger-inger (Neotermes tectonae Damm) dan penjarangan sebagai tindakan pemberantasannya pada jati. Laporan LPH. N0. 158. Bogor. Indonesia.

\section{Pemanenan}

Perhutani 1999 Pedoman penyelenggaraan tebang habis hutan jati. PHT 77 seri produksi 122. Perum Perhutani, Jakarta. Indonesia. 


\section{Daftar Nama Jenis}

\begin{tabular}{ll}
\hline Nama daerah & Nama ilmiah \\
\hline Akor & Acacia auriculiformis \\
\hline Alpukat & Persea americana \\
\hline Bayur & Pterospermum javanicum \\
\hline Beringin & Ficus benyamina \\
\hline Cemara Laut & Casuarina equisetifolia \\
\hline Damar & Agathis loranthifolia \\
\hline Durian & Durio zibethinus \\
\hline Gadung & Dioscorea hispida \\
\hline Gamal & Gliricidia sepium \\
\hline Gmelina & Gmelina arborea \\
\hline Hantap & Sterculia urselta \\
\hline Huru & Litsea sp \\
\hline Jambu Biji & Psidium guajava \\
\hline Jarak Pagar & Jatropha curcas \\
\hline Jeruk Bali & Citrus maxima \\
\hline Johar & Cassia siamea \\
\hline Kedaung & Parkia roxburghi \\
\hline Kemiri & Aleurites moluccana \\
\hline Kelapa & Cocos nucifera \\
\hline Kepel & Stelechocarpus burahol \\
\hline Keranji & Pongamia pinnata \\
\hline Kihiang & Albizia procera \\
\hline Kaliandra & Calliandra calothyrsus \\
\hline Kayu Afrika & Maesopsis eminii \\
\hline Kesambi & Schleichera oleosa \\
\hline Lamtoro & Leucaena leucocephala \\
\hline Mahoni & Swietenia macrophylla \\
\hline Mangga & Mangifera indica \\
\hline Mangium & Acacia mangium \\
\hline Matoa & Pometia pinnata \\
\hline Mimba & Azadirachta indica \\
\hline Mindi & Melia azedarach \\
\hline & \\
\hline
\end{tabular}




\begin{tabular}{ll}
\hline Nama daerah & Nama ilmiah \\
\hline Nangka & Artocarpus heterophyllus \\
\hline Nanas & Ananas comosus \\
\hline Pepaya & Carica papaya \\
\hline Pinus & Pinus merkusii \\
\hline Pulai & Alstonia scholaris \\
\hline Rambutan & Nephelium lappaceum \\
\hline Randu & Ceiba petandra \\
\hline Rasamala & Altingia excelsa \\
\hline Salak & Salacca zalacca \\
\hline Sirsak & Annona muricata \\
\hline Sonokeling & Dalbergia latifolia \\
\hline Srikaya & Annona squamosa \\
\hline Suren & Toona sinensis \\
\hline Saninten & Castanea argentea \\
\hline Sengon & Paraserianthes falcataria \\
\hline Sungkai & Peronema canescen \\
\hline Tayuman & Bauhinia purpurea \\
\hline Tisuk/Waru Gunung & Hibiscus macrophyllus \\
\hline Trembesi & Samanea saman \\
\hline Turi & Sesbania grandiflora \\
\hline Bungur & Lagertromia speciosa \\
\hline Hantap & Sterculia urselta \\
\hline Jabon & Anthocephalus sinensis \\
\hline Ulin & Eusideroxylon zwageri \\
\hline Weru & Albizia procera \\
\hline
\end{tabular}




\section{Keterangan Istilah}

Bebas cabang: Bagian batang utama tanaman yang tidak ditumbuhi cabang dihitung dari permukaan tanah.

Benih unggul: Benih dengan penampilan fisik yang bersih, tidak tercampur kotoran, kemasannya utuh (unggul secara fisik), memiliki daya tumbuh dan daya simpan tinggi (unggul secara fisiologis), serta mampu menghasilkan pertanaman yang seragam, pertumbuhannya lebih cepat dari benih yang umumnya beredar (unggul secara genetik).

Benih bersertifikat: Benih yang dikumpulkan dari sumber benih bersertifikat (diketahui asal-usul genetiknya, ditetapkan oleh badan sertifikasi).

Berkerabat dekat: Memiliki hubungan kekeluargaan yang dekat. Contoh kekerabatan yang sangat dekat adalah benih yang berasal dari satu pohon induk (benih dari satu induk).

Cangkok: Teknik perbanyakan tanaman dengan cara menumbuhkan akar pada bagian batang yang telah dikupas kulitnya sampai lapisan kambium, kemudian membalutnya dengan media lembab. Cabang yang sudah berakar kemudian dipotong dan dijadikan bibit tanaman.

Diameter: Garis tengah dari benda berbentuk tabung. Ukuran diameter batang dapat ditentukan dengan cara mengukur keliling (lilit) batang kemudian dibagi dengan 3,14.

Ekologis: Bersifat hubungan timbal balik antar makhluk hidup, atau antara makhluk hidup dengan lingkungannya.

Generatif: Bagian dari tanaman yang merupakan alat perkembangbiakan melalui penyerbukan. Bagian generatif dari pohon adalah bunga, buah, dan benih.

Genetik: Bersifat diturunkan dari pohon induknya.

Grumusol: Merupakan nama dari salah satu jenis tanah. Ciri dari tanah ini antara lain memiliki kandungan tanah liat tinggi (lebih dari $30 \%)$, mempunyai sifat kembang-susut yang tinggi. Grumusol sering disebut juga sebagai Vertisol atau Margali. Untuk mengenali apakah jenis tanah di lahan petani termasuk jenis ini atau tidak, perlu dikonsultasikan dengan ahli tanah. 
Gulma: Segala jenis tanaman yang tidak diinginkan, yang dapat merusak atau mengganggu pertumbuhan tanaman yang sedang dibudidayakan.

Hama: Segala jenis hewan yang menimbulkan kerugian pada pohon hutan dan hasil hutan seperti serangga, tupai, tikus, babi, dan lainlain. Jenis yang paling sering menjadi hama adalah serangga.

IBA: Singkatan dari Indole Butyric Acid, suatu zat pengatur tumbuh yang tergolong dalam kelompok auksin. Zat ini banyak digunakan untuk memacu pertumbuhan akar dan tunas dalam pembuatan setek.

Kadar air: Persentase kandungan air di dalam suatu materi (misal benih, kayu atau tanah). Penentuan persentase didasarkan pada berat air dan berat materinya.

Kapur Dolomit: Batu kapur yang kemasukan ion magnesium sehingga unsur kalsiumnya digantikan oleh magnesium, biasa ditemukan di bukit batu kapur (sering digunakan untuk bahan keramik, atau pupuk).

Klon: Sekumpulan pohon atau bibit yang kualitas genetiknya sama persis, karena merupakan hasil perbanyakan vegetatif (melalui setek, cangkok, okulasi, atau kultur jaringan) dari satu batang pohon.

Kompos: Pupuk yang terbuat dari pelapukan bagian-bagian tanaman, misalnya dari serasah, pangkasan daun, atau sampah sayuran.

Kultur jaringan: Teknik pembibitan dengan menggunakan bagian jaringan atau organ dari suatu tanam yang dibiakkan secara steril (bebas dari hama penyakit) di dalam ruangan atau media khusus. Teknik ini menghasilkan tanaman dalam jumlah banyak, sampai ribuan, dengan sifat yang sama dengan induknya.

Media tabur: Media yang digunakan untuk mengecambahkan benih sebelum disapih ke polibag.

Okulasi: Teknik memadukan dua sumber tanaman yang berbeda dan membentuk tanaman baru. Dalam teknik ini diperlukan sumber tanaman atas (scion) dan sumber tanaman bawah (root stock). Scion merupakan mata tunas, pucuk atau ranting berasal dari tanaman yang memiliki sifat unggul, yang kemudian ditempelkan atau disambungkan pada tanaman bawah yang merupakan bibit yang memiliki sistem perakaran kuat dan tahan terhadap hama penyakit. 
Paranet: Alat pelindung terhadap panas dan cahaya matahari langsung yang berbentuk seperti jaring atau anyaman, terbuat dari plastik, dapat dibeli di toko, dan biasanya tersedia dalam berbagai tingkat kerapatan (tingkat naungan). Sering juga disebut sebagai shading net.

Penyakit: Penyimpangan dari sifat normal, sehingga tanaman tidak dapat memberi hasil yang baik, dapat disebabkan oleh bakteri, virus, jamur, atau cacing.

Penyerbukan sendiri: Penyerbukan sebuah bunga oleh serbuk sari dari pohon atau klon yang sama.

Perlakuan pendahuluan: Segala macam perlakuan yang diterapkan pada benih sebelum ditabur, agar benih cepat berkecambah.

Pohon benih: Pohon yang dipilih dan dipelihara sebagai penghasil benih.

Pupuk kandang: Pupuk yang berasal dari kotoran binatang misal dari kambing, sapi, atau ayam.

Regosol: Merupakan nama dari suatu jenis tanah. Tanah ini cukup subur, bewarna kelabu. Regosol juga disebut sebagai Inceptisol, Aluvial, Andosol, dan Gleihumus. Untuk mengenali jenis tanah ini petani sebaiknya berkonsultasi dengan ahli tanah.

Sarang: Kondisi media yang cukup memiliki rongga-rongga udara (berpori) namun tidak mudah hancur karena campuran bahan di dalam media saling mengikat. Contoh media yang sarang antara lain serbuk sabut kelapa, sekam padi, atau kompos yang dicampur dengan tanah.

Seresah: Sisa-sisa bagian tanaman yang tidak terpakai. Seresah yang sering dijumpai di benih antara lain serpihan daun, ranting, tangkai buah, kelopak, dan biji gulma.

Shadding net: lihat pada penjelasan paranet.

Skarifikasi: Penipisan kulit benih yang keras, sehingga benih lebih mudah berkecambah, biasanya dilakukan secara mekanis (dengan alat), kimiawi, atau terjadi secara alami.

Setek: Teknik pembiakan tanaman dengan cara mengambil potongan dari bagian vegetatif tanaman (pucuk, batang, daun, atau akar) kemudian ditanam di media untuk ditumbuhkan akar dan daunnya sehingga menjadi bibit yang siap untuk ditanam.

Stump: Bibit yang berasal dari semai atau anakan alami yang telah dihilangkan seluruh daun dan bulu-bulu akarnya sehingga yang tersisa hanya sebagian batang dan sebagian akar utama. 
74 | Pengelolaan Hutan Jati Rakyat

Tajuk: Bagian dari pohon yang merupakan gabungan dari cabang, ranting, dan daun.

Terasering: Teknik penataan lahan miring yang ditujukan untuk mencegah erosi dan tanah longsor dengan cara membuat lahan menjadi bertingkat/berteras.

Terubusan: Tunas atau batang yang tumbuh dari tunggak kayu bekas tebangan.

Vegetatif: Bagian dari tanaman selain bunga, buah atau benih, misalnya daun, batang, pucuk, dan akar. 


\section{Lampiran}

\section{Daftar nama dan alamat desa para petani di Kabupaten Gunungkidul, Yogyakarta yang telah berperanserta di dalam kegiatan pengujian kepraktisan buku panduan ini}

1 Adi Suwito, Desa Giripanggung

2 Adijulan, Desa Karangduwet

3 Adiyanto, Desa Bejiharjo

4 Agus Susila, Desa Bejiharjo

5 Ahmadi, Desa Bejiharjo

6 Badarudin, Desa Girisekar

7 Bakat, Desa Karangduwet

8 Citro W, Desa Bejiharjo

9 Dartasujono, Desa Sumber

10 Dwi, Desa Bejiharjo

11 Edi Sudarni, Desa Girisekar

12 Giyono Saputro, Desa Bejiharjo

13 Giyono, Desa Dadapayu

14 Hadi Sularno, Desa Giripanggung

15 Hadiwinoto, Desa Dadapayu

16 Hardi Subroto, Desa Jeruklegi

17 Harjo Suwarno, Desa Giripanggung

18 Harno Suwito, Desa Kepuhsari

19 Harso Suyono, Desa Candirejo

20 Heri Suyatno, Desa Giripanggung

21 Heri, Desa Katongan

22 Istadi, Desa Bejiharjo

23 Jamiyo, Desa Kepuhsari
24 Joko Narwanto, Desa Sumber

25 Jumirin, Desa Karangduwet

26 Jumiya, Desa Bejiharjo

27 Karsino, Desa Kedungkeris

28 Kismarejo, Desa Candirejo

29 Kisno Sakiran, Desa Bejiharjo

30 Krida Suyarno, Desa Sumber

31 Kuwadi, Desa Karangduwet

32 Lina Juarti, Desa Kepuhsari

33 Mardi Wiyono, Desa Bejiharjo

34 Margiyo, Desa Girisekar

35 Margiyono, Desa Katongan

36 Margono, Desa Bejiharjo

37 Margono, Desa Giripurwo

38 Marjono, Desa Candirejo

39 Markan, Desa Dadapayu

40 Matsi, Desa Dadapayu

41 Medi Suminarno, Desa Girisekar

42 Murjiyanti, Desa Bejiharjo

43 N. Basrudin, Desa Bejiharjo

44 Ngatino, Desa Bejiharjo

45 Purwitoyo, Desa Dadapayu

46 Puryadi, Desa Bejiharjo 
47 Ratijo, Desa Giripurwo

48 Ruhiyem, Desa Kepuhsari

49 Sagiyo, Desa Bejiharjo

50 Sahirin, Desa Giripurwo

51 Samta, Desa Katongan

52 Santhoso, Desa Karangduwet

53 Saryono, Desa Karangduwet

54 Sri Daryanti, Desa Bejiharjo

55 Sudardiyanto, Desa Bejiharjo

56 Sugito, Desa Dadapayu

57 Sugito, Desa Kedungkeris

58 Sugiyanto, Desa Giripurwo

59 Suhani, Desa Bejiharjo

60 Sukimin, Desa Dengok

61 Sukiyardi, Desa Karangduwet

62 Sulistiyono, Desa Bejiharjo

63 Sumadi, Desa Giripanggung

64 Sumanto, Desa Bejiharjo

65 Sumino, Desa Jeruklegi

66 Sumiran, Desa Karangduwet

67 Sumirdjo, Desa Karangduwet

68 Sumirdjo, Desa Karangduwet

69 Sunarya, Desa Karangduwet

70 Sunarya, Desa Karangduwet

71 Sungkono, Desa Giripanggung
72 Supardi, Desa Girisekar

73 Suparman, Desa Giripurwo

74 Suparmin S, Desa Sumber

75 Suparmin, Desa Giripurwo

76 Suparto, Desa Dadapayu

77 Supoyo, Desa Giripanggung

78 Supriyanto, Desa Dengok

79 Suradal, Desa Kedungkeris

80 Suradi, Desa Bejiharjo

81 Suranto, Desa Katongan

82 Suroyo, Desa Dadapayu

83 Sutarno, Desa Bejiharjo

84 Suwandi, Desa Giripanggung

85 Suwito, Desa Bejiharjo

86 Tukijan, Desa Giripurwo

87 Tukirin, Desa Dadapayu

88 Viftin Agustina, Desa Dadapayu

89 Wadirin, Desa Dengok

90 Wagiya, Desa Kedungkeris

91 Wagiyono, Desa Bejiharjo

92 Wahyudi, Desa Katongan

93 Warijan, Desa Giripanggung

94 Wasiran, Desa Giripurwo

95 Widiyanto, Desa Dengok

96 Wuhono Hs, Desa Kedungkeris 


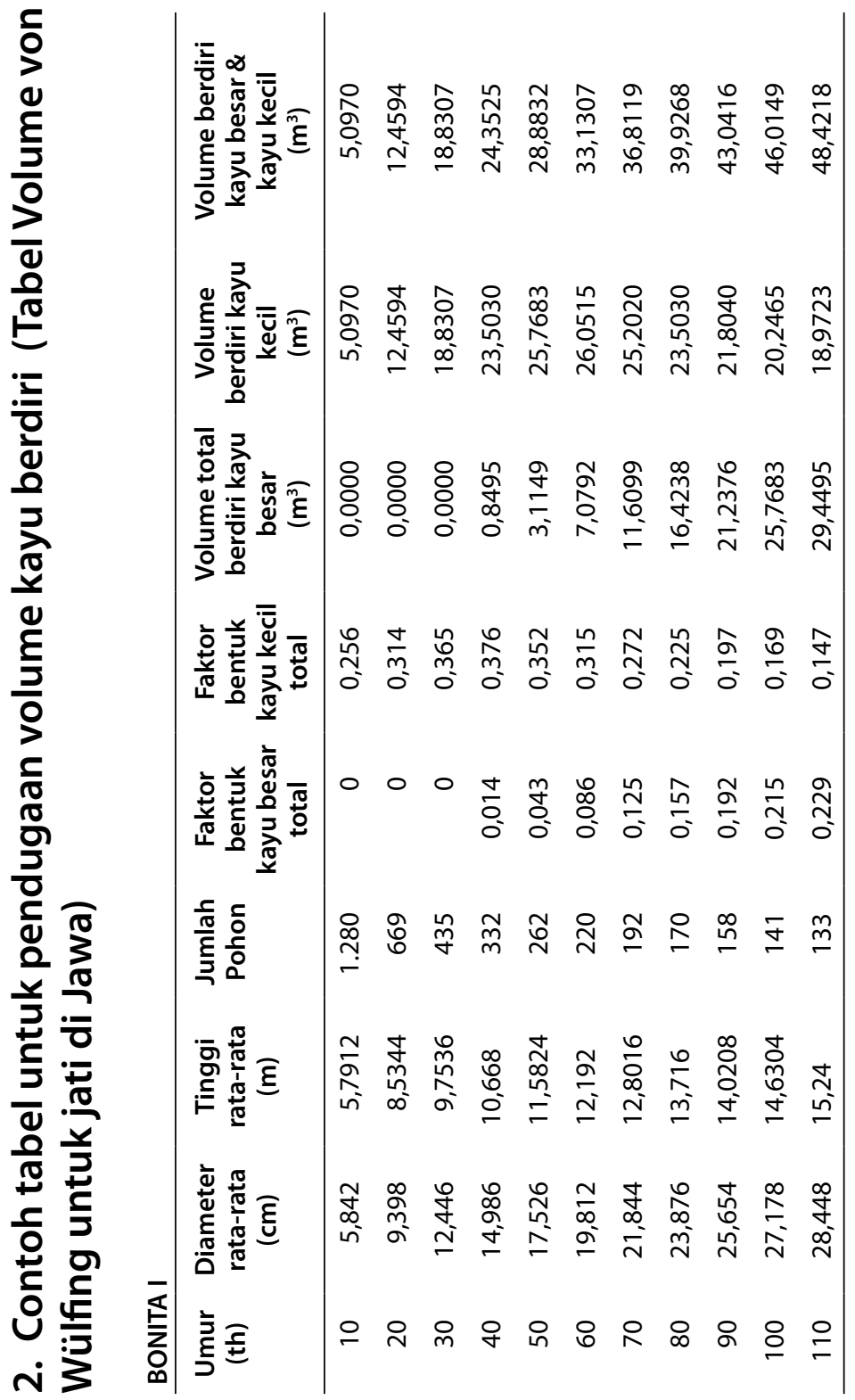




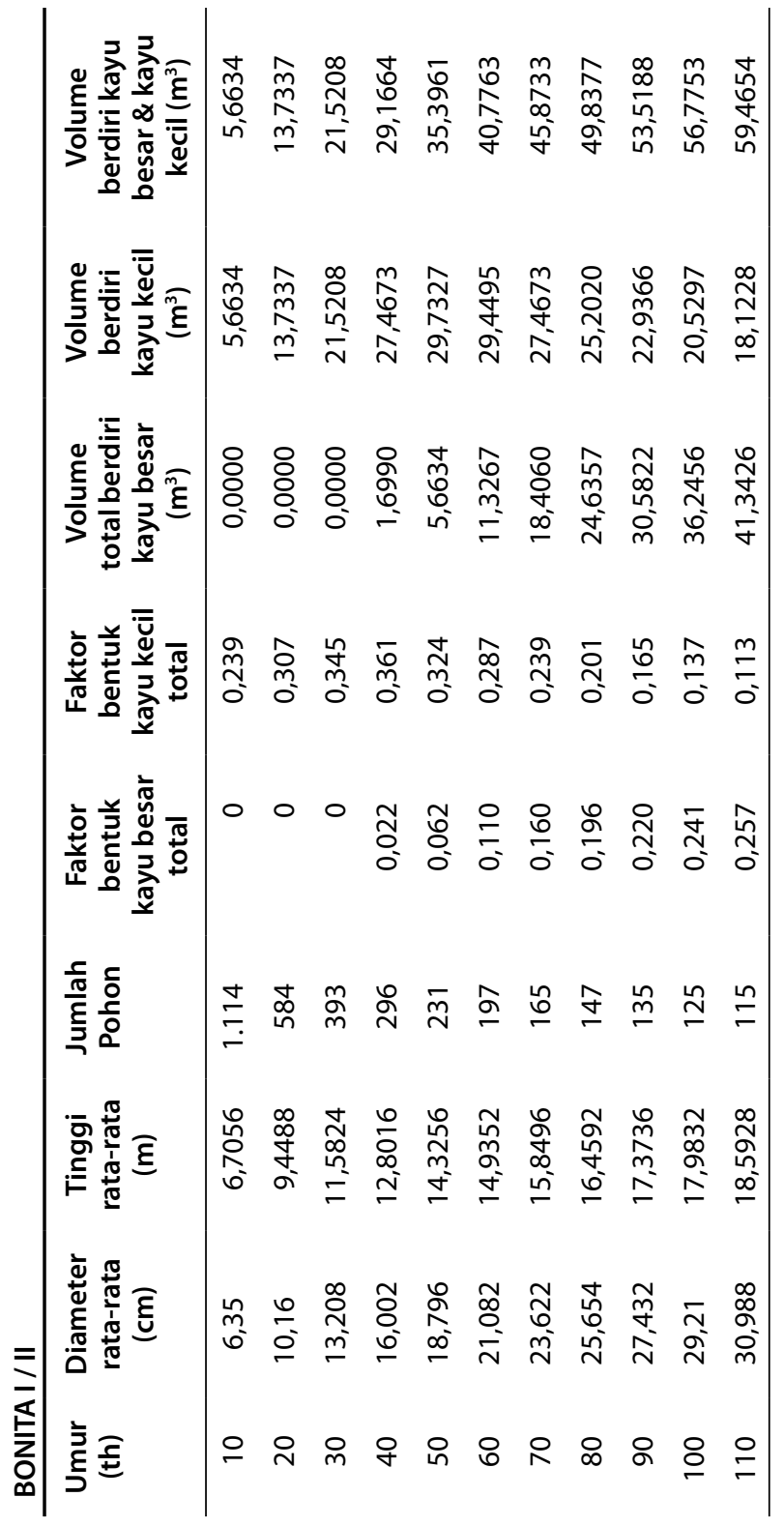




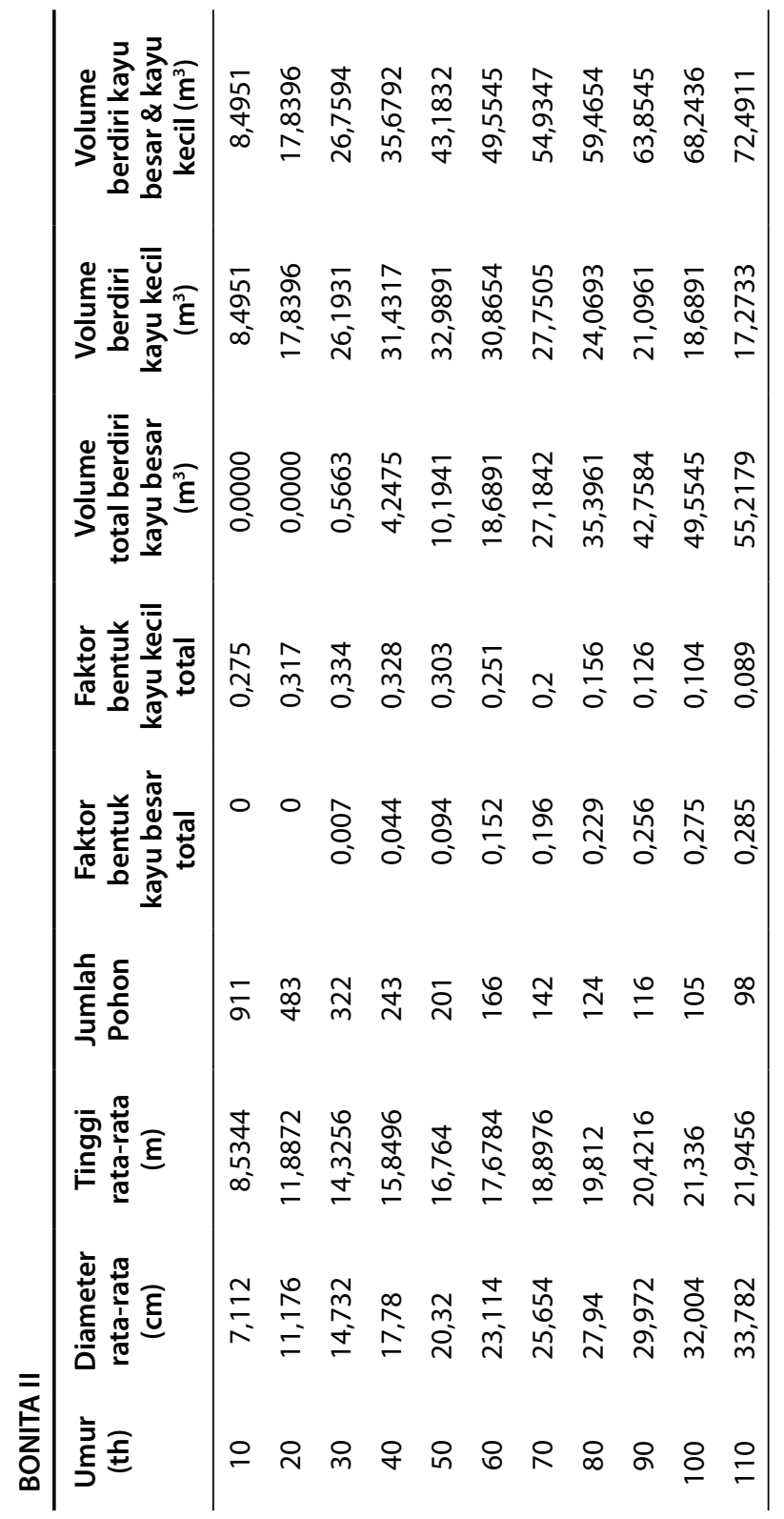




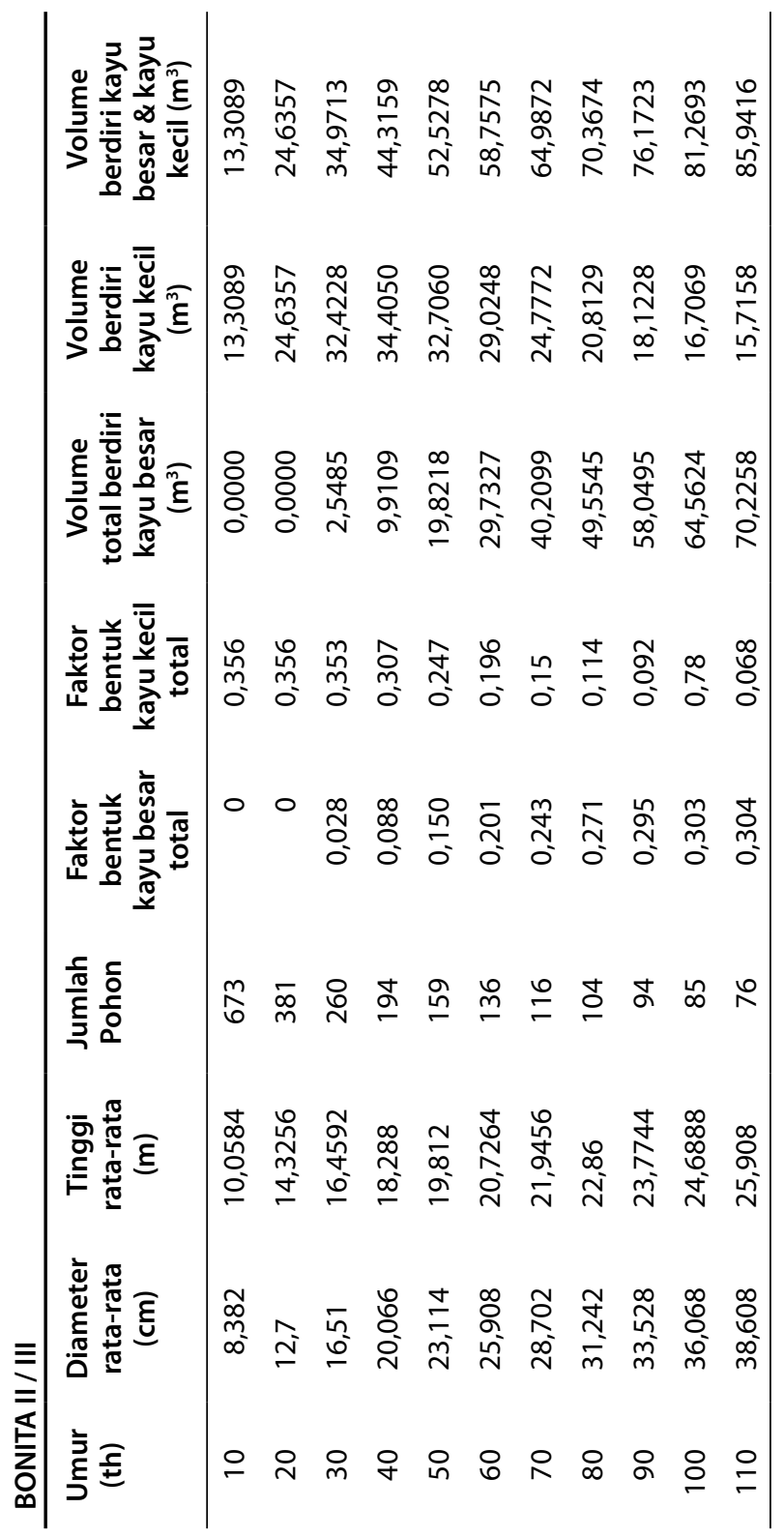




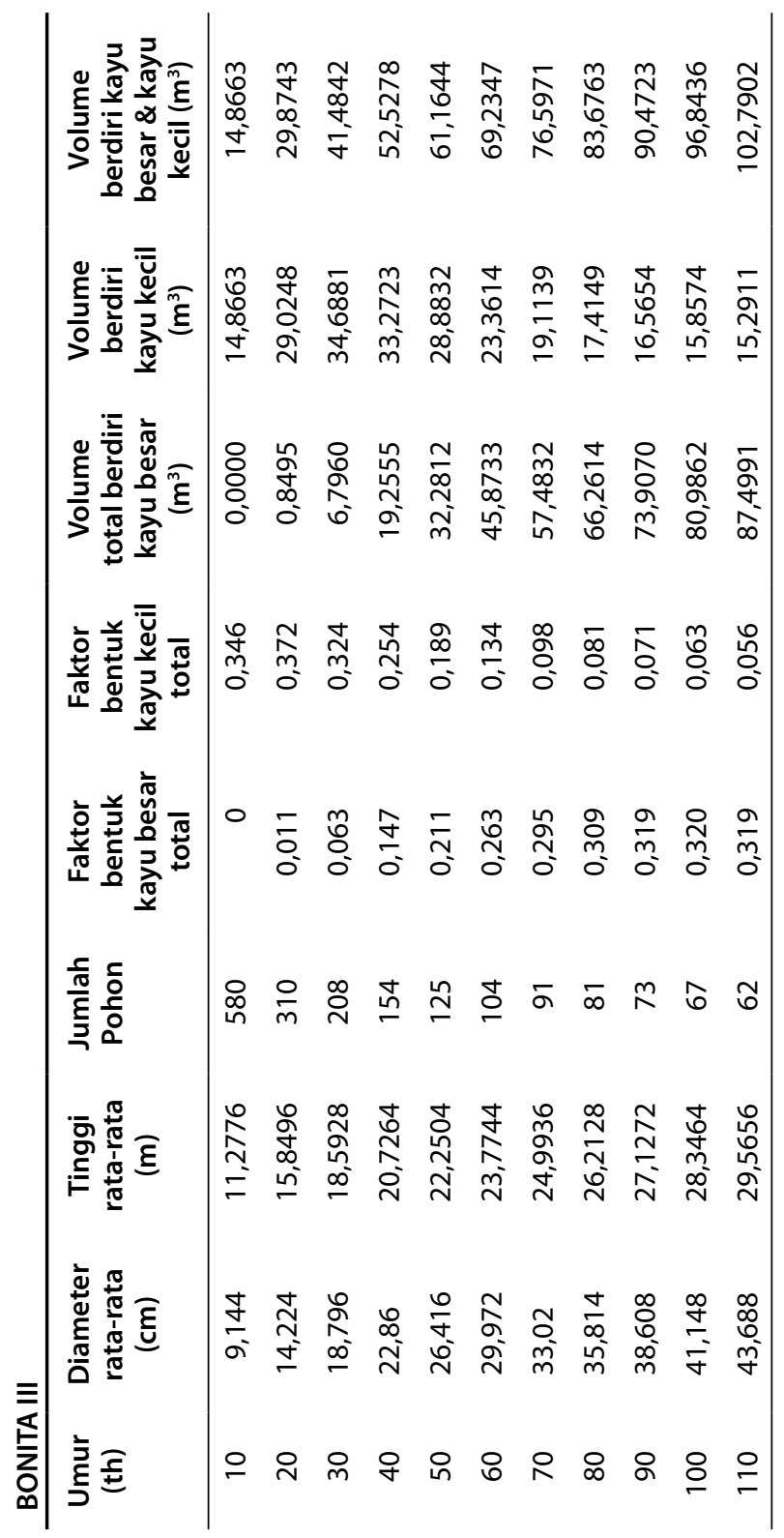




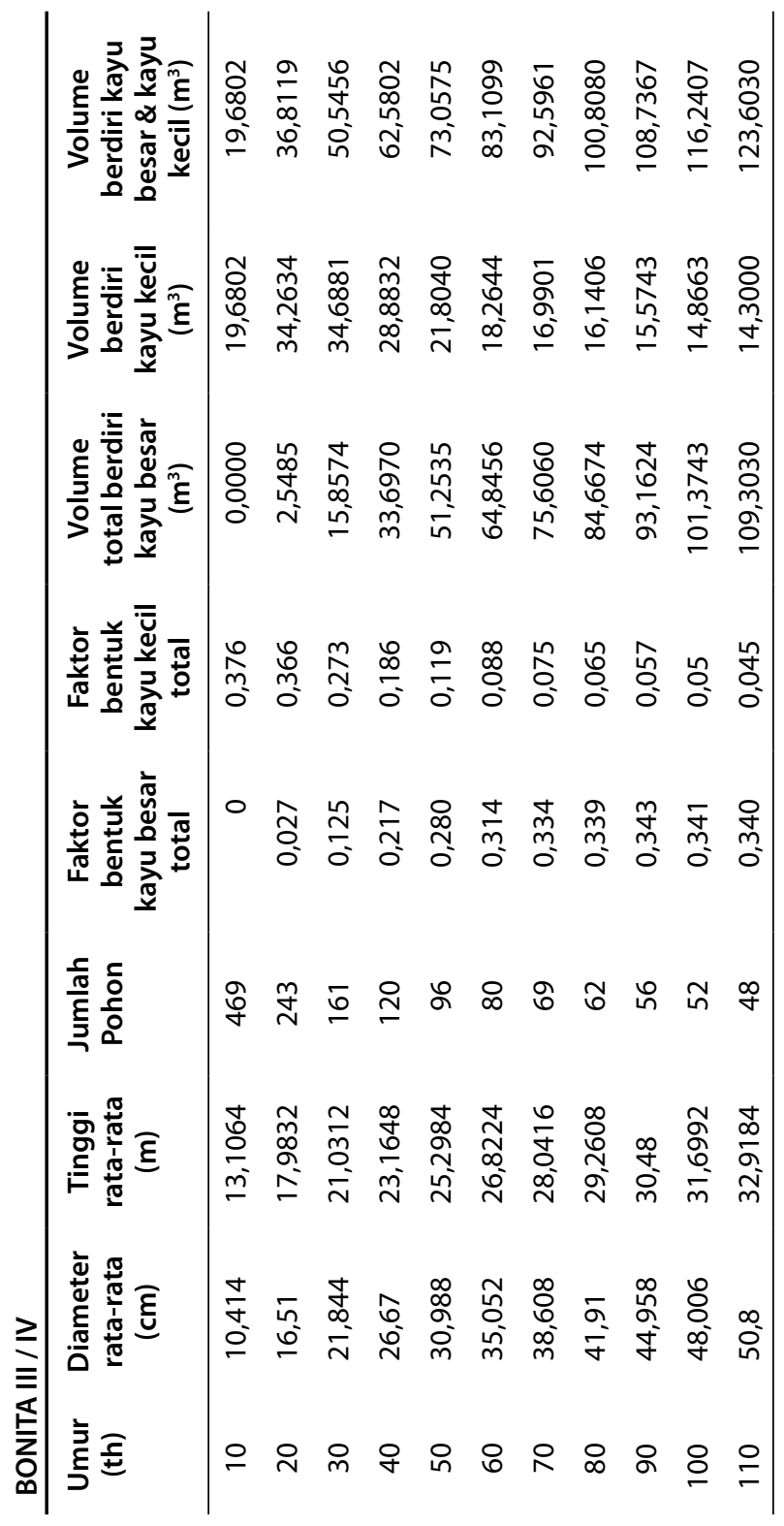




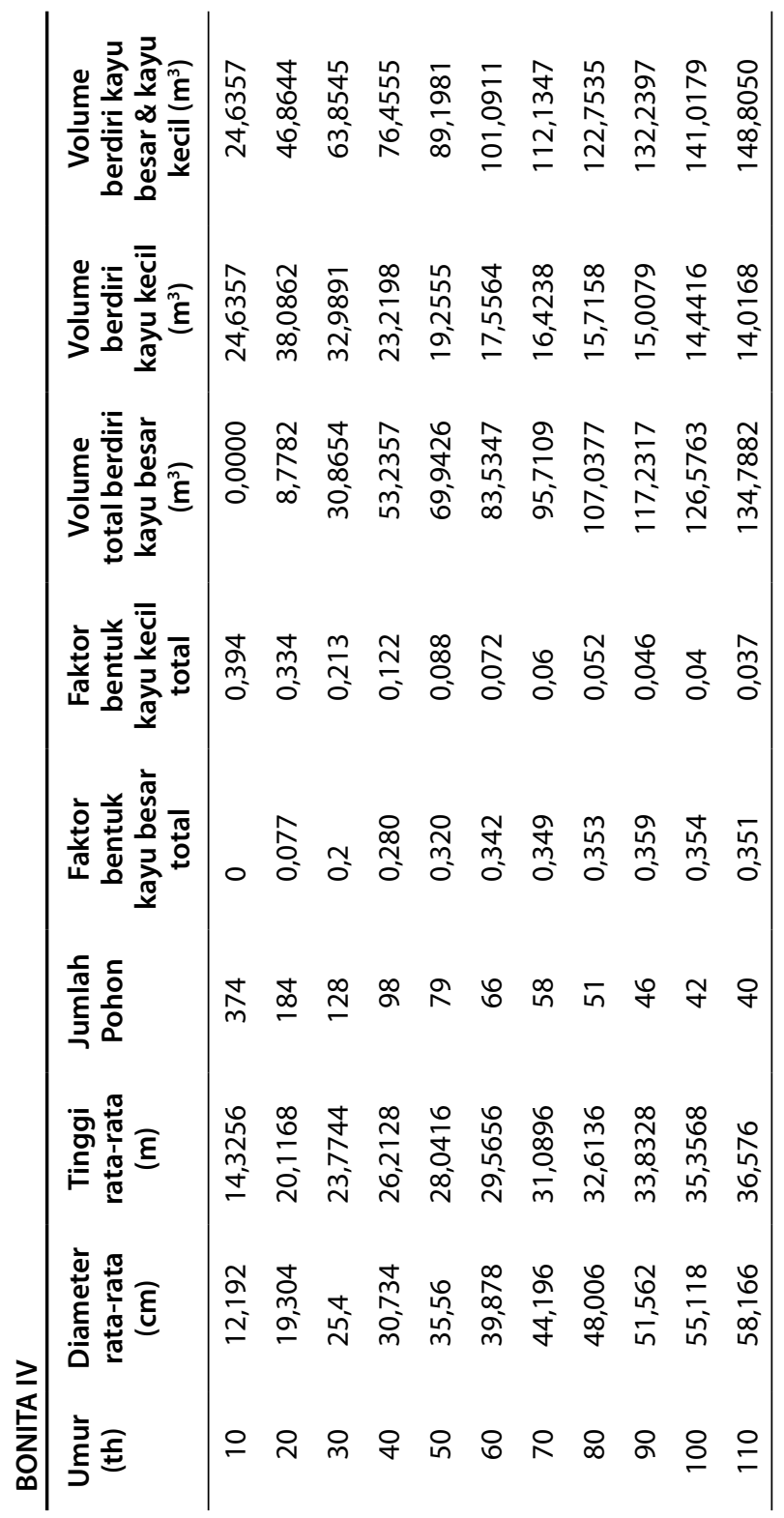




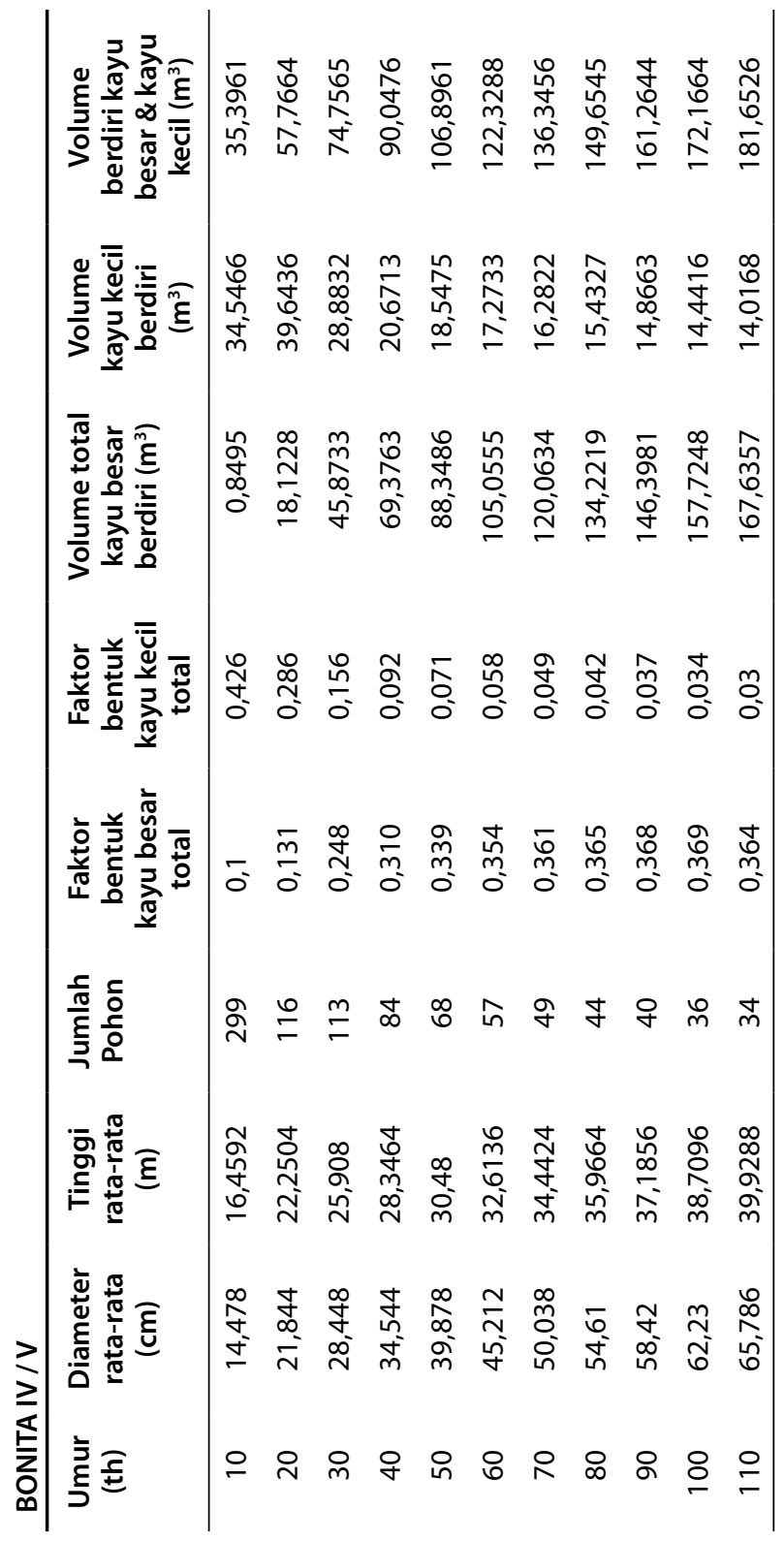




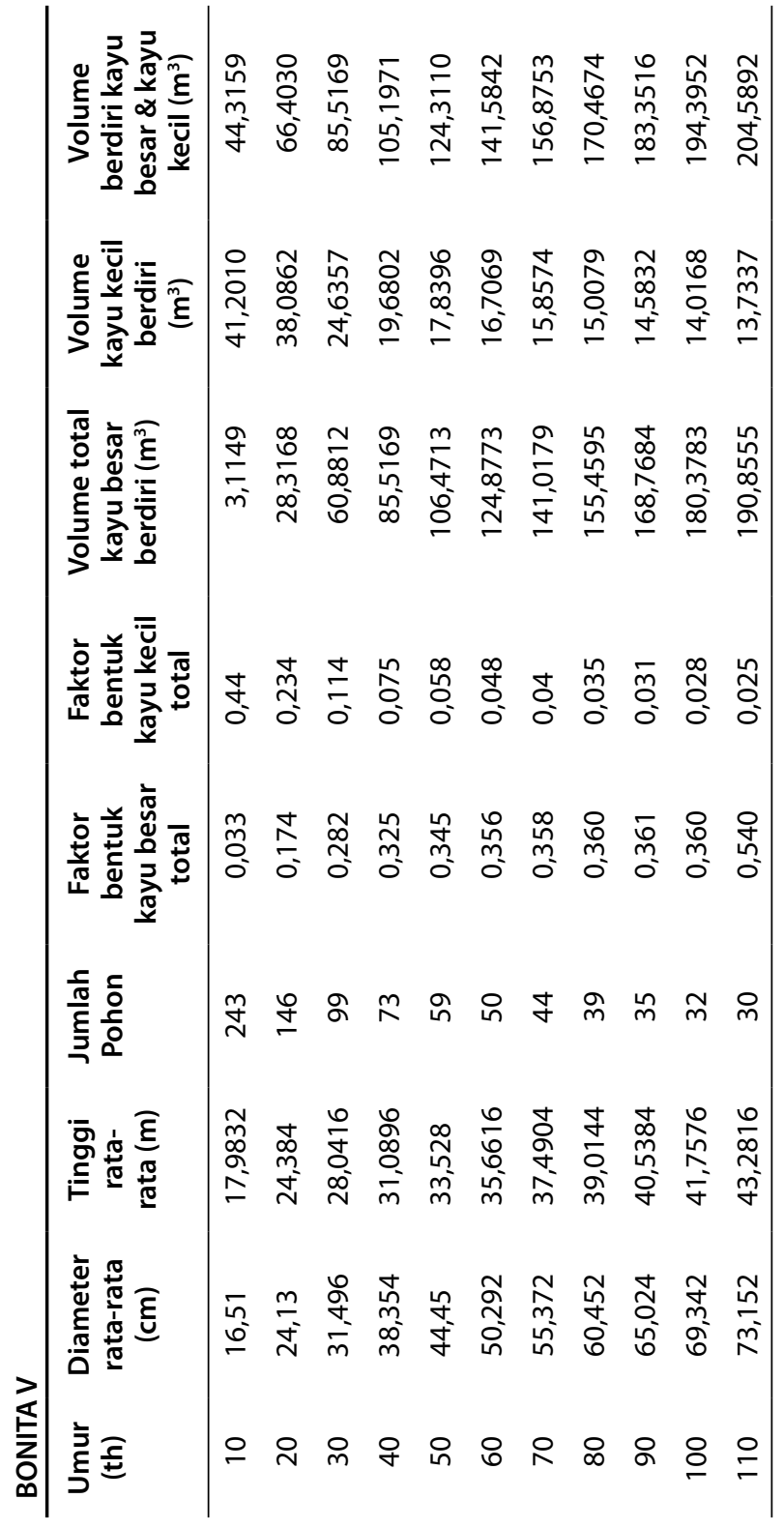




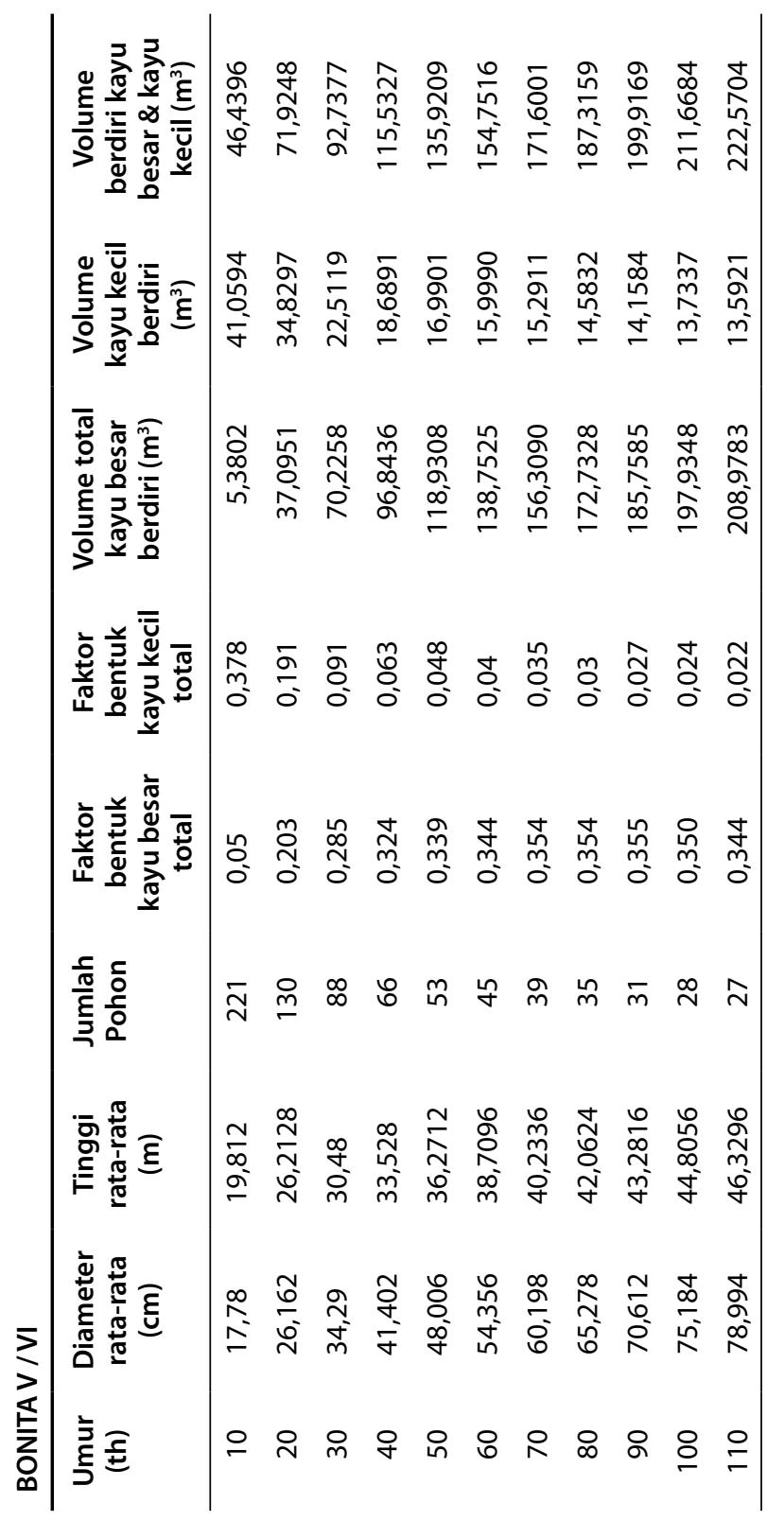




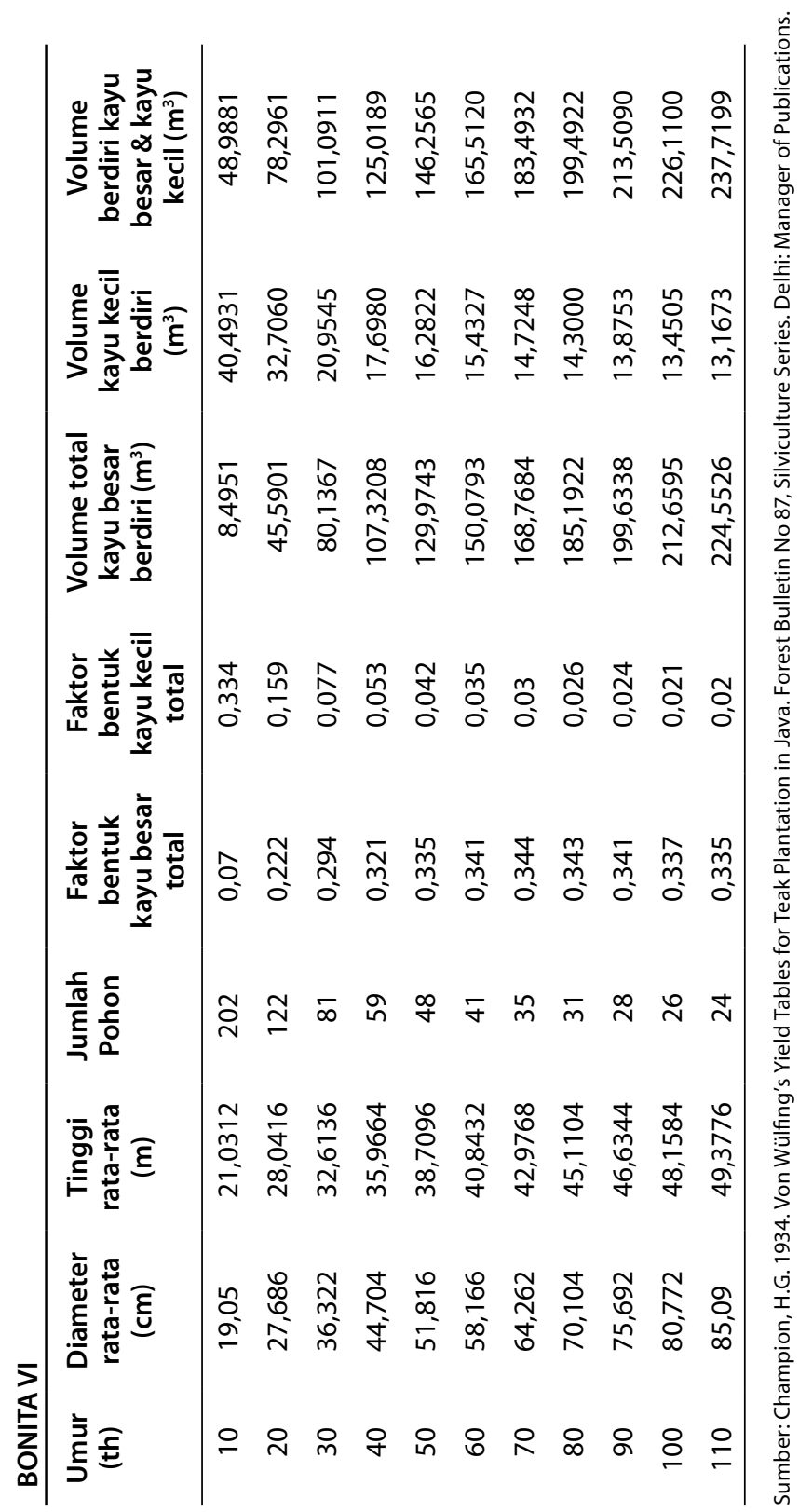




Kebiasaan para pemilik hutan jati rakyat untuk membiarkan jati tumbuh tanpa pengelolaan telah menyebabkan hutan jati rakyat memiliki kualitas yang rendah. Berbagai pertanyaan kemudian muncul ketika petani mulai tertarik untuk mengelola hutan jatinya dengan lebih baik. Buku ini mencoba memberikan panduan praktis untuk menjawab pertanyaan-pertanyaan tersebut. Secara runut dan rinci, buku ini menerangkan tentang teknik pemilihan pohon induk, pengadaan benih, pembuatan bibit, penanaman, pemupukan, penjarangan, pemangkasan, pengendalian hama/penyakit, dan pemanenan. Agar lebih mudah dipahami, teknik-teknik tersebut dilengkapi dengan ilustrasi, foto, atau tabel.

Buku ini agak berbeda dengan buku petunjuk budidaya jati pada umumnya karena dirancang dengan bahasa yang sederhana untuk petani pengelola hutan jati rakyat. Permasalahan-permasalahan yang dihadapi dalam pengelolaan hutan jati rakyat yang kadang spesifik seringkali belum terjawab oleh buku-buku pedoman yang selama ini ada. Bagaimana menanam jati pada lahan berbatu, bagaimana teknik penjarangan pada tegakan yang umurnya tidak seragam, bagaimana memelihara terubusan dari tunggak, dan bagaimana menebang dengan pola tebang butuh, adalah beberapa hal yang dicoba dijawab oleh buku ini. Beberapa teknik di dalam buku ini juga merupakan adopsi dari beberapa kearifan tradisional dari petani jati di Kabupaten Gunungkidul.

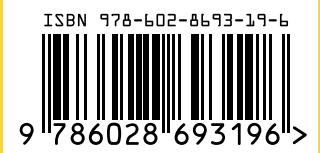

\section{Australian Government}

Australian Centre for

International Agricultural Research

\section{Center for International Forestry Research}

CIFOR memajukan kesejahteraan manusia, konservasi lingkungan dan kesetaraan melalui penelitian yang berorientasi pada kebijakan dan praktek kehutanan di negara berkembang. CIFOR merupakan salah satu dari 15 pusat penelitian dalam Kelompok Konsultatif bagi Penelitian Pertanian International (Consultative Group on International Agricultural Research - CGIAR). CIFOR berkantor pusat di Bogor, Indonesia dengan 